(2) norden 



\section{Evaluation of passive samplers for the moni- toring of contaminants in sediment and water}

Monitoring of POPs and PCBs in international monitoring programmes

Martin M. Larsen, Ian Allan, Kristoffer Nces, Elisabeth Nyberg, Katrin Hoydal

TemaNord 2009:563 
Evaluation of passive samplers for the monitoring of contaminants in sediment and water Monitoring of POPs and PCBs in international monitoring programmes

TemaNord 2009:563

(C) Nordic Council of Ministers, Copenhagen 2009

ISBN 978-92-893-1914-0

Print: Kailow Express ApS

Copies: 80

CoverPhoto: Passive samplers at Frederik d. 7's island at Sisimiut, Greenland

/Martin M. Larsen, NERI

Printed on environmentally friendly paper

This publication can be ordered on www.norden.org/order. Other Nordic publications are available at www.norden.org/publications

Printed in Denmark

Nordic Council of Ministers

Store Strandstræde 18

DK-1255 Copenhagen K

Phone (+45) 33960200

Fax (+45) 33960202

\section{Nordic Council}

Store Strandstræde 18

DK-1255 Copenhagen K

Phone (+45) 33960400

Fax (+45) 33111870

www.norden.org

Author:

Martin M. Larsen

National Environmental Research Institute, Aarhus University

Ian Allan

Kristoffer Nes

Norwegian Institute for Water Research, NIVA

Elisabeth Nyberg

Swedish Museum of Natural History, NRM

Katrin Hoydal

Environmental Agency, US

\section{Nordic co-operation}

Nordic cooperation is one of the world's most extensive forms of regional collaboration, involving Denmark, Finland, Iceland, Norway, Sweden, and three autonomous areas: the Faroe Islands, Greenland, and Åland.

Nordic cooperation has firm traditions in politics, the economy, and culture. It plays an important rol in European and international collaboration, and aims at creating a strong Nordic community in a strong Europe.

Nordic cooperation seeks to safeguard Nordic and regional interests and principles in the global community. Common Nordic values help the region solidify its position as one of the world's most innovative and competitive. 


\section{Content}

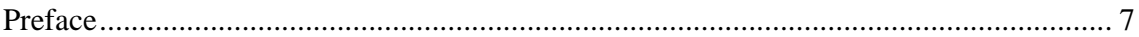

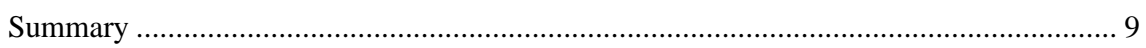

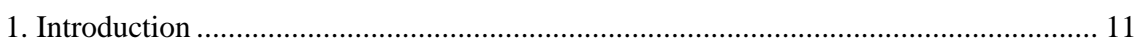

1.1 Background of the passive sampling trial survey ............................................... 11

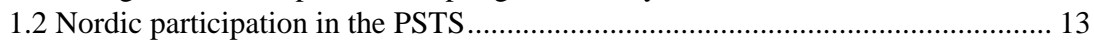

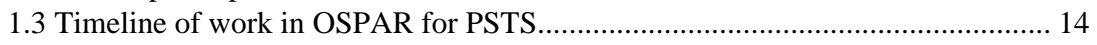

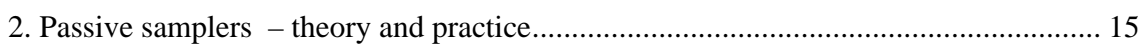

2.1 Application of passive sampling to organic substances..................................... 17

2.2 Application of passive sampling to metals ......................................................... 18

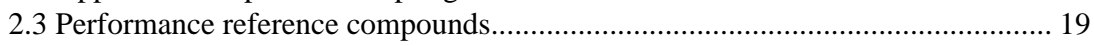

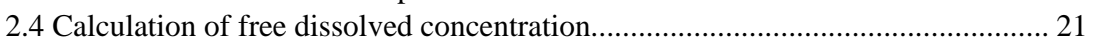

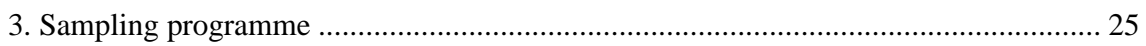

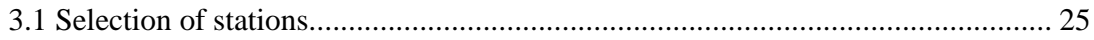

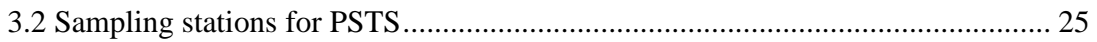

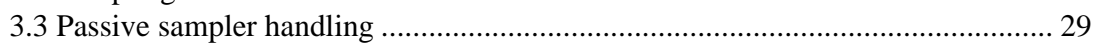

3.4 Extraction and analysis for biota and sediment ................................................ 30

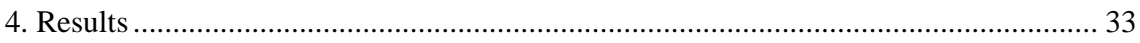

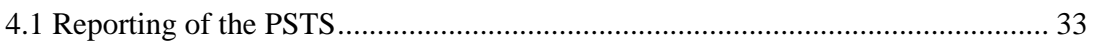

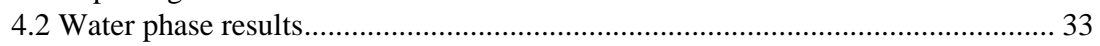

4.3 Results from measurements in sediment pore waters ......................................... 37

4.4 Results from the work with mussel and sediments .............................................. 39

4.5 Comparison of passive samplers and mussel/sediment samples........................... 40

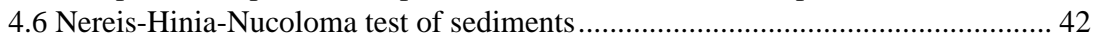

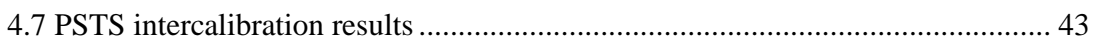

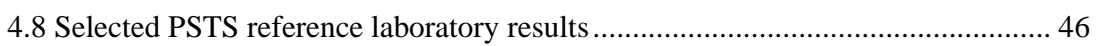

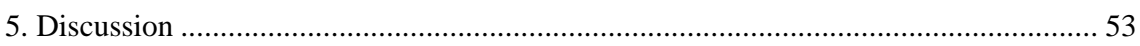

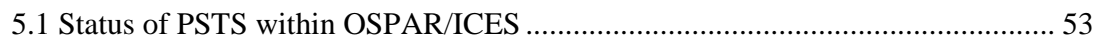

5.2 Experience with PSTS in the Nordic countries.................................................. 53

5.3 Experience with passive samplers in the Nordic countries.................................. 54

5.4 Use of passive samplers in national monitoring .................................................. 55

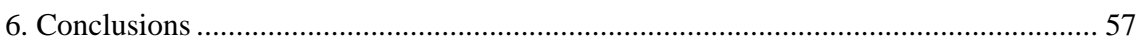

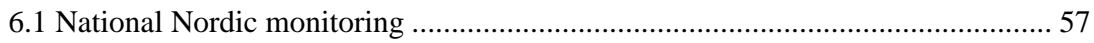

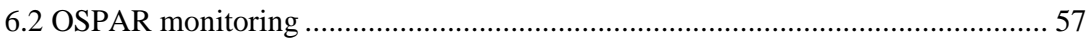

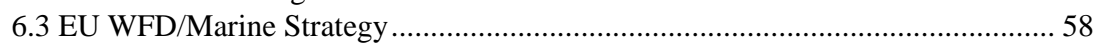

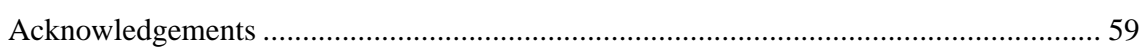

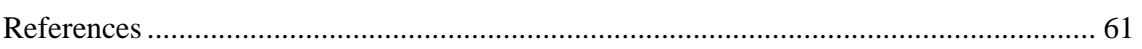

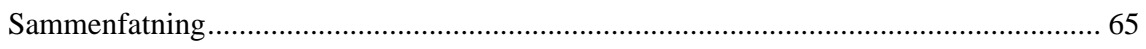

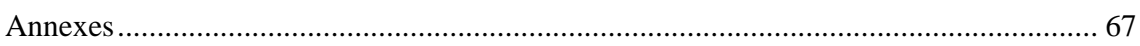

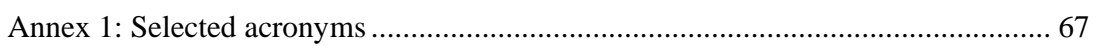

Annex 2: Use of passive samplers in the Nordic countries......................................... 69

Annex 3: OSPAR and PSTS ................................................................................. 71

Annex 4: Program for Passive Sampler møde på Søminestationen ved Holbæk (Danmark) ........................................................................................... 74

Annex 5: The participating institutions and examples of passive sampler experiences

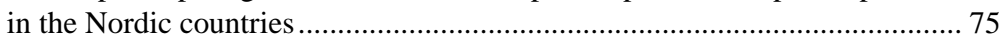

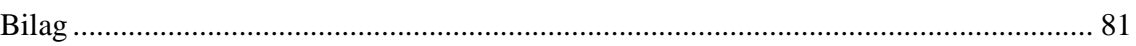

Data sheets reported to PSTS (water 1-8, sediment $1-5$ )............................................ 81 



\section{Preface}

This project aimed to evaluate the potential usefulness of passive sampling devices for the monitoring of hydrophobic compounds and establish possible connections to current sediment and mussel-watch monitoring programmes as part of: national strategies, the Oslo-Paris convention (OSPAR for the North Sea), Helsinki convention (HELCOM for the Baltic Sea) and the upcoming monitoring in the European Union Water Framework Directive (WFD) and the Marine Strategy Framework Directive.

Passive sampling is a realistic alternative to commonly used bottle sampling monitoring tasks such as comparisons of trace contaminant levels with fixed environmental quality standards. Passive sampling therefore represents an attractive tool in support of river basin management plans for water districts.

The strategy of this project was to sample fjords/areas where significant differences in levels of the persistent organic pollutants polychlorinated biphenyls (PCB) and polyaromatic hydrocarbons (PAH) were expected, based on a priori knowledge from existing monitoring programmes and participants' knowledge and expertise.

The basis of this project was a passive sampling trial survey suggested by two working groups of the International Council for the Exploration of the Sea (ICES), and sanctioned by OSPAR, to investigate passive samplers for hydrophobic compounds with the aim to validate the use of passive samplers in the water phase, and give the participants experience in the use of passive samplers for both water and sediment in order to secure transfer of knowledge on the use of passive samplers within the ICES community. 



\section{Summary}

\section{Passive Sampler Trial Survey}

Denmark, the Faroe Islands, Norway and Sweden participated in the joint Oslo-Paris convention (OSPAR) and International Council for the Exploration of the Sea (ICES) passive sampler trial survey (PSTS) with funding from the Sea and Air Group (HLG) of the Nordic Council of Ministers.

Passive samplers spiked with performance reference compounds were prepared at RIKZ. Two sets of passive samplers were deployed at the various sites for 2-3 months and after collection sent to RIKZ and NIVA for extraction and analysis.

\section{Use of passive samplers in the Nordic countries}

Despite the first use of passive sampling devices almost two decades ago, passive sampler use within regulatory monitoring strategies is not common practice in the Nordic countries, with the exception perhaps of Norway. A short overview of existing knowledge and use of passive samplers in the Nordic countries is provided in Annex 2.

\section{Passive sampler evaluation}

Passive samplers were deployed at 9 sites in the Nordic countries and Greenland, and mussels were collected at the same sites to compare passive sampler results with the mussel-watch approach usually applied in national monitoring. In parallel, sediments were sampled from 6 sites, and analysed by standard methods and through extraction by passive samplers for sediments.

Calculation of the sampling rates between reference laboratory and all national laboratories varied a factor of two, partly due to differences in the more advanced calculation performed by the reference laboratory, and partly due to the differences in measured performance reference PAH concentrations. The calculation of sampling rates will be harmonised through an OSPAR/ICES guideline for passive samplers currently under development.

Calculation of the water phase concentration of PAHs in NIVA and RIKZ samples differed with up to a factor of 10 , with concentrations in the reference laboratory generally higher than the national laboratory. Part of the difference was due to the sampling rate calculation, but also to 
analysis of PAHs in passive samplers. Comparability between laboratories are expected to improve with experience and intercalibration of passive sampler methods, where QUASIMEME have started a round for passive samplers. The experience from the passive sampler programme in the Netherlands indicates that analysis of passive samplers can be at least as reproducible as that of mussel-watch type of monitoring.

Comparison of the content of contaminants in mussels and calculated water phase concentration from passive samplers indicated an increasing accumulation rate as a function of $\mathrm{K}_{\mathrm{ow}}$. The accumulation rate varied with a factor of 10 between stations, with the most contaminated sites showing a higher accumulation rate than the less polluted sites.

The results of the pore water to sediment PAH concentrations were more varied, but also indicated a tendency for higher $\mathrm{K}_{\mathrm{ow}}$ substances to accumulate more in the sediments compared to pore water concentrations. Comparing pore water to water column concentrations, it was shown that sediment acted as a source of benzo(a)pyrene at NIV01, whereas most other stations pore water to surface waters was around 1:1, indicating equilibrium between sediment and surface waters for benzo(a)pyrene. Lower $\mathrm{K}_{\text {ow }}$ PAHs were typically found in excess in surface water, whereas benzo(ghi)perylene and indeno(123-cd)pyrene were higher in the pore water. For NER01, sediment pore water was lower for all PAHs and hence, the sediment here was working as a sink for the whole range of PAHs investigated.

The project have shown that passive samplers as silicone sheets can be used for monitoring programmes, especially in areas where mussels are difficult to find or have problems surviving. If mussels and passive samplers were investigated in parallel, factors for using passive samplers instead of mussels can be derived locally, but not necessarily on a more global scale. The development of guidelines and quality assurance of analysis are underway, so before OSPAR accommodates passive samplers in its monitoring programmes, only assessment criteria are missing. These can be derived directly from the EU Water Framework Directive for the calculated water concentration, so within a time frame of 2-3 years it could become part of the next monitoring strategy of OSPAR. 


\section{Introduction}

In recent years, several review articles on passive sampling techniques have been published from Górecki \& Namiesnik (2002), Stuer-Lauridsen (2005), Vrana et al. (2005), Namiesnik et al. (2005) and most recently Kot-Wasik et al. (2007) and Seethapathy et al. (2008). They all point to techniques that are close to maturity, with Stuer-Lauridsen scoring only semipermeable membrane devices (SPMDs) as ready for use, but with a note on low density polyethylene (LDPE)/silicone tubing as an upcoming technique.

Passive sampling devices for nonpolar organic contaminants can be used in two modes: equilibrium and integrative sampling. Equilibrium sampling is undertaken when a passive sampler is deployed for a sufficiently long period of time for the contaminant concentration in the sampler to reach equilibrium with that in the water. The contaminant concentration in the water is then estimated using sampler-water partition coefficients, $K_{\mathrm{sw}}$. When the exposure time is kept below the time required to reach equilibrium, integrative sampling is conducted and the concentration in the water can be estimated from $K_{\mathrm{sw}}$ and the analyte- and condition-specific uptake rate, $R_{s}$ (expressed in equivalent volume of water cleared of analyte by the sampler per unit of time). Values for $K_{\mathrm{sw}}$ and $R_{s}$ are generally determined through laboratorybased batch experiments and calibrations. Since it is difficult to apply laboratory-based uptake rates to field conditions, techniques using Performance Reference Compounds (PRCs) have been developed to estimate $R_{s}$ values in situ (see section 2.3 below).

\subsection{Background of the passive sampling trial survey}

In 2006 OSPAR and ICES agreed to hold a Passive Sampler Trial Survey (PSTS), using silicone rubber (PDMS) passive samplers spiked with PRCs and analysed both by national laboratories and a central laboratory in the Netherlands (RIKZ). The activities are outlined in figure 1.1, and the intention was to create an "intercalibration" between deployed samplers analysed nationally and in the central laboratory. The Nordic participation was sponsored by the Nordic Council of Ministers (NMR), and all Scandinavian passive samples where analysed in Norway by NIVA as well as RIKZ in the Netherlands. Information related to the PSTS can be found at http://www.passivesampling.net.

The PSTS was lead by a steering group consisting of Foppe Smedes (Chairman of the ICES Working Group on Marine Sediments in relation to polution, WGMS), Ian Davies (WGMS), Céline Tixier (WGMS), Patrick Roose (Marine Chemistry Working Group, MCWG), Ton van der 
Zande (MCWG) and Jacek Tronczyski (MCWG). Foppe Smedes from the former National Institute for Coastal and Marine Management (RIKZ), the Netherlands, was chief investigator and coordinator.

The re-organisation of environmental institutions in The Netherlands in 2008 resulted in the disappearance of RIKZ and relocation of employees to other institutions. It has not been possible to obtain raw data for the Nordic participants, therefore only results presented at the OSPAR or ICES working group meetings and the Annual Science Conference of ICES in Helsinki in 2008 are available for this report. The data presented from the Nordic samplers in this report have all been analysed by NIVA.

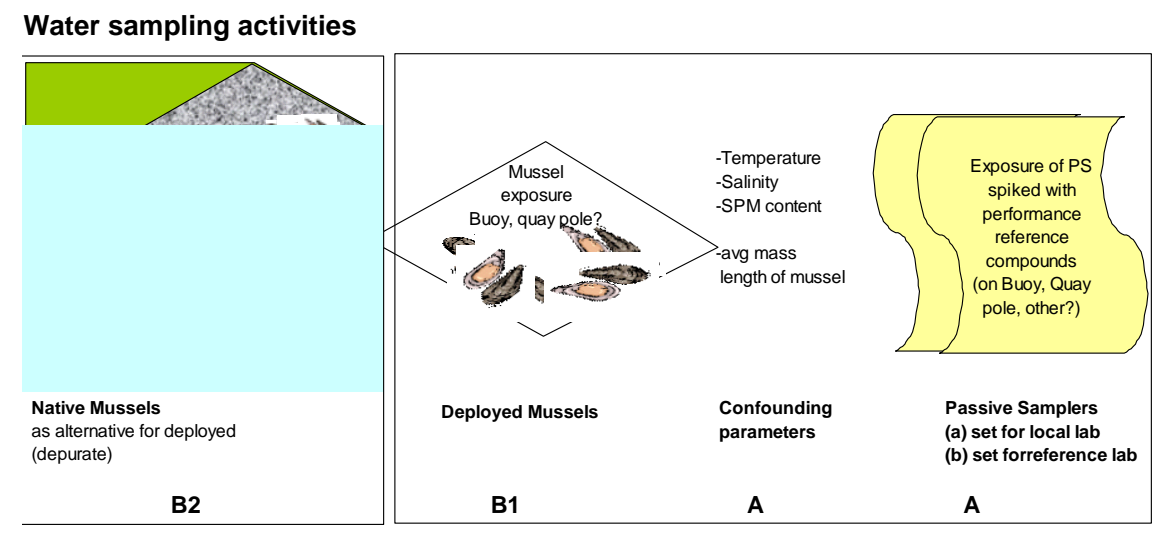

Sediment sampling activities

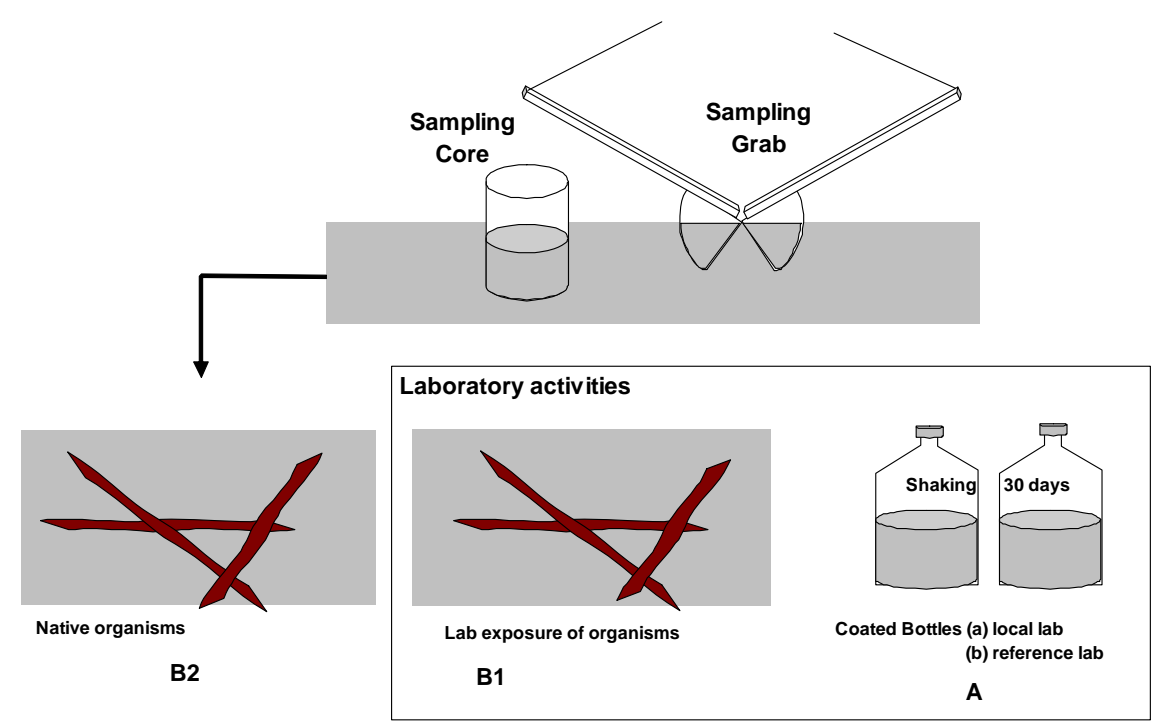

Figure 1.1 Overview of activities in the Passive Sampling Trial Survey conducted by OSPAR/ICES (Smedes et al. 2006). Steps marked A was mandatory and core activities of the PSTS, $B$ activities were for validation of the PSTS. 


\subsection{Nordic participation in the PSTS}

NIVA and NERI decided early on to participate in the OSPAR/ICES PSTS project, but in order to extend the Nordic participation the current NMR project was initiated, to allow the Faroe Islands and Sweden to participate. NIVA reported directly to the PSTS steering group, whereas NERI distributed the samplers to the Faroe Islands and Sweden, and reported the results to the PSTS steering group. The setup for Nordic participation is shown in figure 1.2.

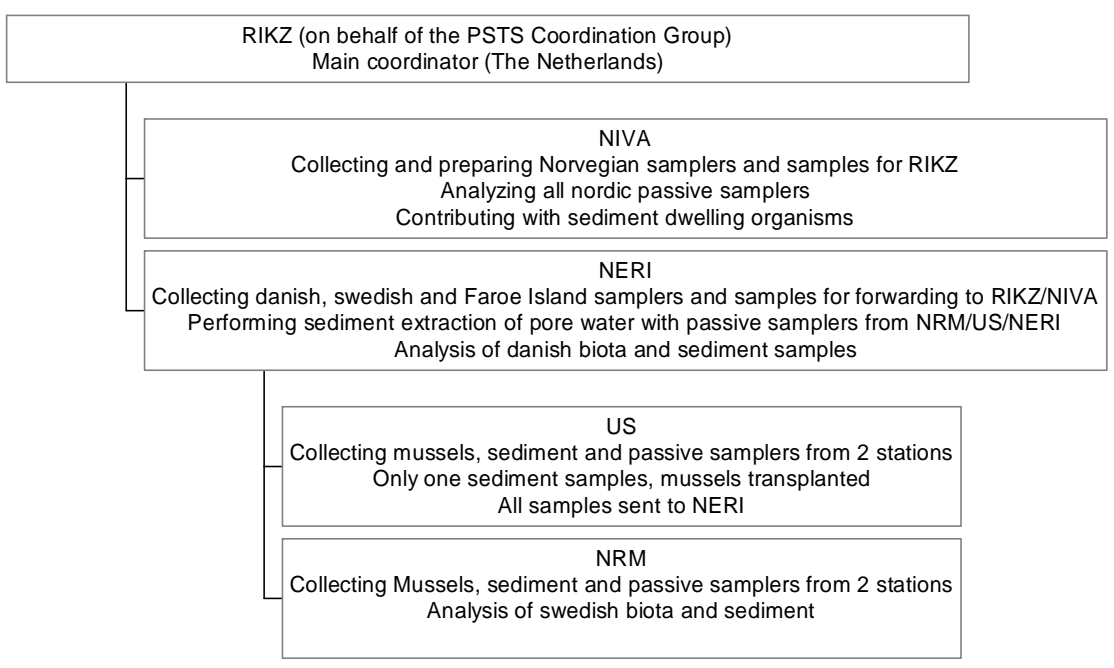

Figure 1.2 Nordic participation and route of samplers from RIKZ and back.

Sampling was later extended to Sisimiut, Greenland, so the final number of NERI stations (including Sweden and the Faroe Islands) for the water phase was 8, and for sediment 5 samples. Sisimiut sampling took place in August 2007, so data were not presented at the ICES ASC in 2007. NIVA participated in the PSTS with 3 sampling sites for water and 2 for sediments, including exposure of worms in sediment.

The individual institutions participating from the Nordic countries and their involvement in monitoring in the OSPAR area are described in Annex 6. 


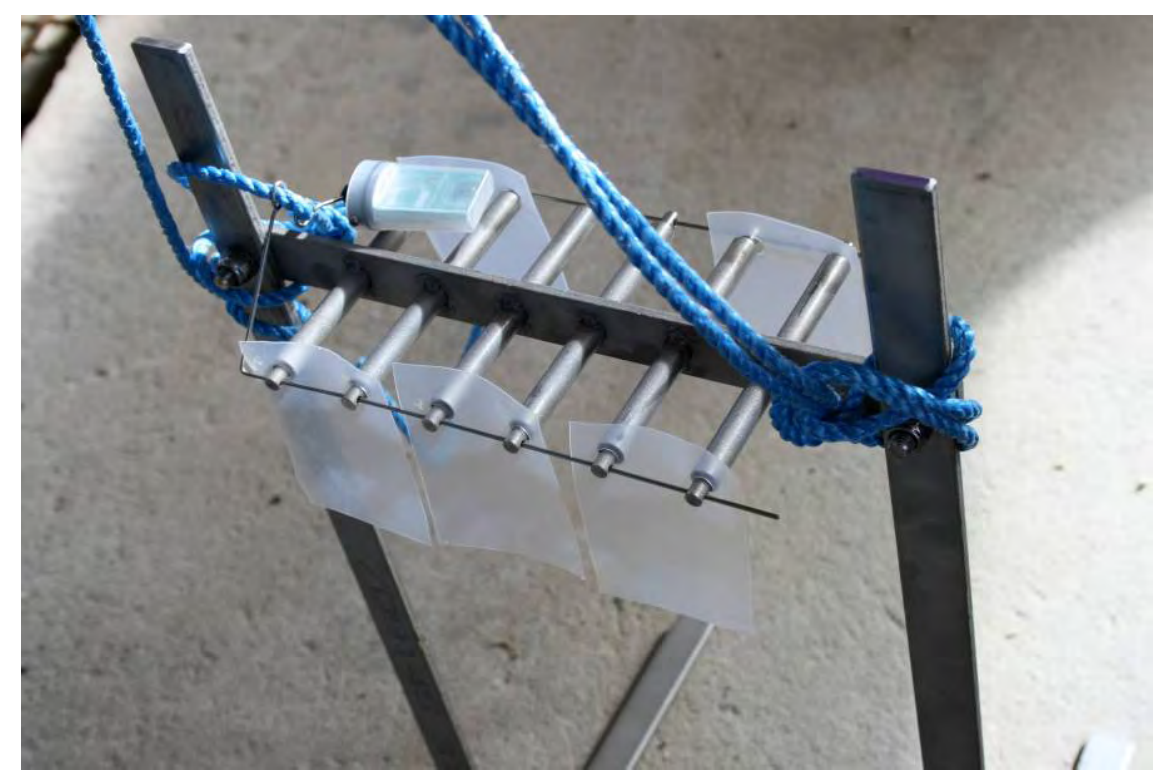

Figure 1.3 Passive sampler ready for deployment in Greenland, silicone sheets in two thicknesses and a temperature/light data logger.

\subsection{Timeline of work in OSPAR for PSTS}

The suggestion for a Passive Sampler Trial Survey was a joint effort by the ICES Marine Chemistry Working Group (MCWG) and the Working Group on pollution in relation to Marine Sediments (WGMS), starting in 2005 up to the first presentation of results at ICES' Annual Science Conference (ASC) in Helsinki in 2007 and at a SIME meeting in 2008. In parallel, the OSPAR MON and SIME groups, reporting to the OSPAR ASMO, have followed the work. The timeline and relevant documents are listed in Annex 3 and can be found on the OSPAR website. 


\section{Passive samplers - theory and practice}

Passive samplers are usually deployed to assess the time-weighted average (TWA) concentration of organic substances or metals in the water phase. A wide range of samplers are available, and are often specific to a given range of substances, usually governed by their hydrophobicity $\left(K_{\mathrm{ow}}\right)$. The types of substances and range of $K_{\mathrm{ow}}$ are listed below. The list is not exhaustive, but covers the samplers used in the Nordic countries so far, or rated as having a high usability in the review articles.

Most of the samplers consist of a receiving phase behind a membrane. The membrane is often said to serve the purpose of ensuring diffusion control, but the water boundary layer is generally controlling the uptake for $\log \mathrm{K}_{\mathrm{ow}}>5$. The membrane acts as a selector for what substances can penetrate to the receiving phase and/or as a physical barrier to hold the receiving phase in place. The membrane is made from a variety of different materials, depending on the application. Sampler receiving phases (sorbents) are widely varied and range from de-ionized water and air to organic solutes, resins or acidic compounds. The combinations of barrier and receiving phase select the analytical target compounds and are optimized for different purposes. The silicone sheet sampler used in this project relies only on the receiving phase and has no barrier. In cases like this, a solid receiving phase is generally used. Analysis is done either directly on the receiving phase or after extraction to an organic solvent.

Passive samplers can work in two main regimes, either kinetic (linear uptake) or equilibrium sampling modes. In the kinetic regime, the sampler is not in equilibrium with the medium, and the concentration in the sampler is controlled by kinetics (usually based on diffusion). This sampling mode is general for most of the field samplers used, as the uptake rate is fairly slow. Usually kinetic samplers are exposed over such a short time span that the uptake concentration is linearly dependant on the deployment time. For samplers in the equilibrium-sampling mode, the uptake rates are high or exposure time is so long that equilibrium (or nearequilibrium) has been achieved. In this case, calculation of contaminant 
concentration in water $\left(C_{\text {water }}\right)$ is straightforward, since only the contaminant partition coefficient $\left(K_{\mathrm{SW}}\right)$ between the passive sampling device and water is required. $C_{\text {water }}$ can then be estimated from the contaminant concentration measured in the sampler $\left(C_{\text {sampler }}\right)$ :

$$
C_{\text {water }}=\frac{C_{\text {sampler }}}{K_{\text {sw }}}
$$

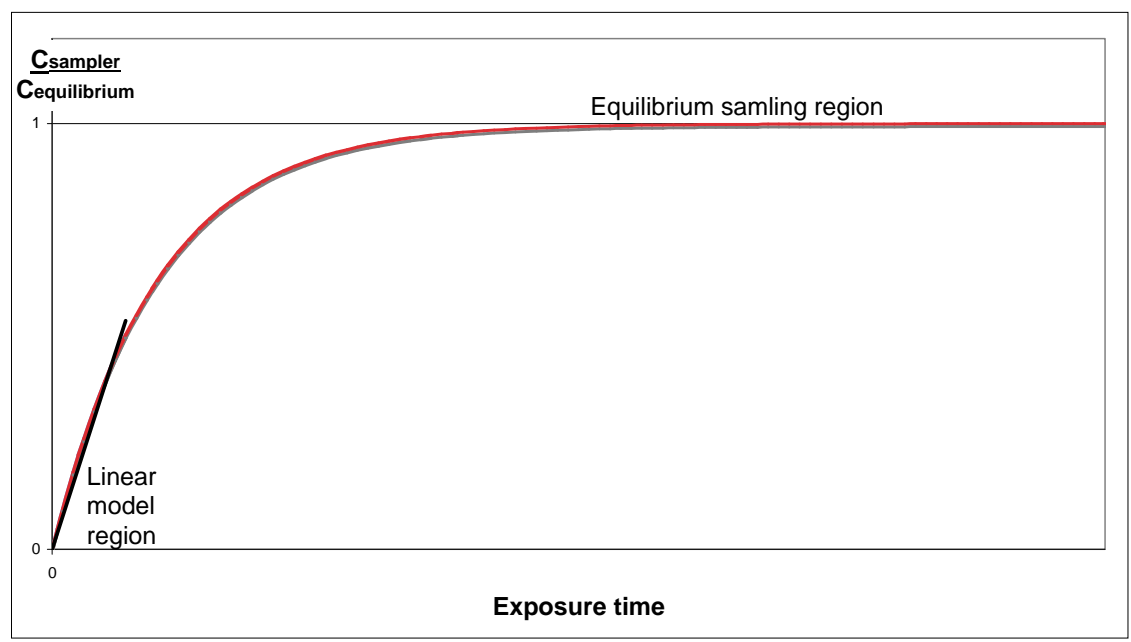

Figure 2.1 General models for passive samplers: sampling in the kinetic (linear) or equilibrium regions, depending on the uptake rate or exposure/deployment time of the passive sampler (after Stuer-Lauridsen \& Birkved 2000). The Y-axis is arbitrary units depending on the equilibrium concentration $\left(C_{\text {equilibrium }}\right)$.

For passive sampling devices working in the kinetic regime, timeweighted average contaminant concentration in water can be calculated from $C_{\text {sampler }}$ (mass per unit of volume of sampler) using a priori knowledge of the volume of the sampler $\left(V_{\text {sampler }}\right)$, the exposure time $(t)$ and of the sampling rate $\left(R_{s}\right)$ :

$$
C_{T W A, w a t e r}=\frac{C_{\text {sampler }} \times V_{\text {sampler }}}{R_{s} \times t}
$$

It is worth noting, that equilibrium sampling assumes the concentration in the water phase to be constant for the duration of deployment, whereas the kinetic sampling calculated concentration are expected to give the time-weighted average (TWA) of water concentration during deployment. In the case of non-polar organic substances, whether a sampler is working in the equilibrium or kinetic sampling regime is directly dependent on the duration of the exposure, the sampler-water partition coefficient $K_{\mathrm{SW}}$, capacity and configuration (surface area and volume) of the sampler and water turbulences around the sampler. However, since this is dependent on $K_{\mathrm{sw}}$, such regime will be compound-specific and for com- 
monly observed SPMDs exposures, for example, analytes with $\log K_{\mathrm{OW}}<$ 5 are found to reach equilibrium within days while those above this threshold are found to be in intermediary or kinetic regimes for period of weeks to months. This can be documented with the use of performance reference compounds (see below).

Passive samplers were initially developed for contaminant monitoring in the air as early as the 1970s, and a number of American and European standard methods have been developed for the application in routine air and work place monitoring (Seethapathy et al. 2008, see also the American Society for Testing and Materials, www.astm.org, and the European committee for standardization, www.cen.eu). Passive samplers for water were introduced in the late 1980s and are on the verge of being introduced into marine monitoring programmes. No international guidelines currently exist for using passive samplers in marine waters, but work is underway in the OSPAR/ICES organisation based on the PSTS experience. In the European area, an ISO standard on passive sampling is under development. In 2009, an ISO guideline for selection and use of tools for measuring the bioavailability of contaminants in soils and sediments included some comments on passive samplers. British Standard Institute published the first guideline to standardise passive sampling in 2006.

\subsection{Application of passive sampling to organic substances}

The passive sampler selected for this PSTS was silicone rubber. A number of alternative samplers for persistent organic pollutants (POPs) characterised by high octanol water partition coefficients have also been used for in situ monitoring (for a full list see Stuer-Lauridsen (2005)):

- solvent-filled dialysis membranes for screening of lipophilic compounds by Södergren (1987)

- SPMD (semi-permeable membrane devices) for lipophilic compounds ( $\log \mathrm{k}_{\mathrm{ow}}>3$ ) consisting of a low density polyethylene tube with triolein by Huckins et al. (1990)

- Empore ${ }^{\circledR}$ discs with C18 resin for lipophilic compounds developed by Verhaar et al. (1995) and used in situ with the addition of a polysulfone and modified with polyethylene membrane to form Chemcatcher ${ }^{\mathrm{TM}}$ by Kingston et al. (2000)

- Passive sampler (TMP) trimethylpentane/polyethylene sampler for chlordane and dieldrine by Peterson et al. (1995)

- Polar organic chemical integrated sampler (POCIS) with a membrane covering chromatographic materials for polar organic compounds by Alvarez et al. (1999) 
- Silicone rubber/low density Poly ethylene sheets for PAHs and PCBs (Booij et al. 2000)

- Solid phase micro extraction (SPME) with various materials and no membrane for various compounds by Verbruggen et al. (2000)

Of the devices mentioned above, Stuer-Lauridsen ranked the applicability for SPMDs as high (having been used in more than 100 scientific publications), and TMP, solvent-filled dialysis membranes and LDPE/silicone rubber and Empore ${ }^{\circledR}$ discs as medium from the number of citations in scientific publications. He concluded that SPMD, Empore ${ }^{\circledR}$ disc and TMP were the ones qualified for application in aquatic environment for nonpolar (log $\mathrm{K}_{\text {ow }} 3-6$ ) substances, but some advances with polar substances have been found for POCIS and Empore ${ }^{\circledR}$ disc techniques, and that performance reference compounds (see section 2.3) should be included in all field exposures of passive sampling devices. It was also stated that $>75 \%$ of the organic substances listed in the water quality criteria for the US, the EU Water Framework Directive and OSPAR can be monitored by passive sampling devices.

Passive sampling may also be applied to sediments with the aim to measure either the total bioaccessible fraction of contaminant available for desorption or the truly dissolved contaminant concentration (or related chemical activity) in pore water. This can be done by varying the size of the fraction of sediment placed in contact with the sampler (in batch experiments) and the configuration of the sampler itself. Polymeric materials such as polyoxymethylene (POM) have been used for the measurement of contaminant concentrations in sediment pore waters. Samplers are brought into contact with a sufficiently large volume of sediment and shaken until equilibrium between the fraction on the sampler and the concentration in pore water is obtained (after 2-4 weeks). If samplerwater partition coefficients are known, pore water concentrations can be calculated from the mass of analyte absorbed into the sampler. The choice of polymer material used for passive sampling has been discussed by Rusina et al. (2007), with the conclusion that silicone sheets offer the best critical properties for passive sampling of substances with high $\mathrm{K}_{\mathrm{ow}}$.

\subsection{Application of passive sampling to metals}

A number of techniques have been used for the passive sampling of trace metals in water:

- Low density polyethylene tube with acidic compounds for double charged metal ions or PIMS reagents for collecting mercury vapour (Seethapathy et al. 2008) 
- Permeation liquid membrane (PLM) made of 1,10-didecyldiaza-18crown-6(22DD) and lauricacid(1:1ratio)in1:1(v/v) with a receiving phase of 1,2-Cyclohexylene-aminotetraaceticacid (CDTA) or pyrophosphate solution for $\mathrm{Cu}, \mathrm{Pb}, \mathrm{Ni}$ (Seethapathy et al. 2008)

- Diffusion gradient thin film (DGT) with an acrylamide gel with different metal-binding resins incorporated for various metals (Seethapathy et al. 2008).

Of these, the DGT are regarded as the method of choice today, and are used routinely by NIVA.

\subsection{Performance reference compounds}

The use of Performance Reference Compounds (PRCs) is a major step forward in the quantification of exchange-kinetics for contaminant transfer from water into the samplers. This technique is based on the assumption that mass transfer into or out of the sampler is an isotropic phenomenon where the same processes affect the transfer of compounds in and out of the sampler. PRCs are substances (typically deuterated PAHs or PCBs not usually found in the environment) that are pre-loaded into the passive sampling device. It is possible to follow the loss of PRCs from the sampling device (first order dissipation or depuration rate, $k_{e}$ ), and estimate the kinetics of uptake of analytes of interest from the kinetics of offloading the built in PRCs. In situ uptake rates $\left(R_{s}\right)$ can be calculated for analogues to PRC compounds based on $K_{\mathrm{SW}}$ for the selected PRC $\left(R_{S, P R C}=\right.$ $\left.k_{e, P R C} V_{s} K_{\mathrm{SW}}\right) . \mathrm{R}_{\mathrm{s}}$ can only be calculated with reasonable certainty if 10$90 \%$ of the PRC remains in the sampling device following deployment. Often, more than one PRC is necessary since those with low $K_{\mathrm{SW}}$ are often found to be completely released from the samplers while others with high $K_{\mathrm{SW}}$ values are commonly fully retained in the sampling devices. Therefore, a set of PRCs with a wide range of $\mathrm{K}_{\mathrm{Sw}}$ is needed to

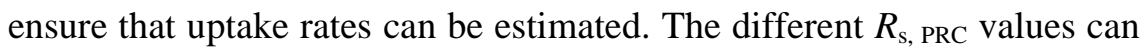
then be used to estimate the uncertainty of the overall $R_{\mathrm{s}}$. $K_{\mathrm{SW}}$ values have to be measured for each analyte, PRC and sampler type in use, so in practice, the smallest number of PRCs that can be used for a sampler is around 5, preferably with $K_{\mathrm{Sw}}$ values with a range spanning 2-3 orders of magnitude, but the higher the number of PRCs used is, the more accurate estimates of $R_{s}$ will be obtained.

Another use of PRCs is to establish the sampling regime of the compounds/sampler. If less than $10 \%$ of the PRC is left after deployment, compounds with similar $\mathrm{K}_{\mathrm{Sw}}$ or below can be assumed to have reached equilibrium, and care should be taken in interpretation of the results. It also seems that the use of PRC to calculate $R_{\mathrm{s}}$ takes into account any biofouling, a very relevant benefit for highly productive coastal waters. In 
strong sorbing or reactive passive samplers though, the use of PRCs is not possible, as the PRC will be completely retained (no isotropy of uptake and release).

The procedure for calculating concentrations based on PRCs was outlined in the PSTS programme description and for silicone rubbers a number of $\mathrm{K}_{\mathrm{SW}}$ values have been made available in the PSTS documentation (note that the $\mathrm{K}_{\mathrm{sw}}$ in table 2.1 are the partition coefficient between silicone sheets and water). These can be found below in 2.4.1 and 2.4.2, and results from the Nordic passive samplers are given in chapter 4 , together with an example calculation.

Table 2.1 Substances to be included in the PSTS and their partition coefficient $\left(\mathrm{K}_{\mathrm{sw}}\right)$ between water and silicone sheets. For some PAHs also $\mathrm{K}_{\text {ow }}$ for octane to water partition coefficient are given.

\begin{tabular}{|c|c|c|c|c|c|}
\hline Targets & Abbreviations $^{\mathrm{S}}$ & $\log \left(K_{o w}\right)$ & $\log \left(K_{s w}\right)$ & PRCs & $\log \left(K_{s w}\right)$ \\
\hline Hexachlorobenzene & $\mathrm{HCB}$ & & 5.03 & & \\
\hline РСВ010 & & & & CB10 & 4.52 \\
\hline РCB018 & CB18 & & 5.18 & CB14 & 5.07 \\
\hline PCB021 & & & & CB21 & 5.37 \\
\hline РCB028 & CB28 & & 5.46 & CB30 & 5.21 \\
\hline PCB031 & CB31 & & 5.43 & & \\
\hline PCB044 & CB44 & & 5.76 & CB50 & 5.67 \\
\hline PCB052 & CB52 & & 5.75 & CB55 & 5.94 \\
\hline PCB055 & & & & CB78 & 5.99 \\
\hline PCB101 & CB101 & & 6.22 & CB104 & 6.16 \\
\hline PCB105 & CB105 & & 6.35 & & \\
\hline РCB118 & CB118 & & 6.35 & & \\
\hline PCB138 & CB138 & & 6.68 & CB145 & 6.64 \\
\hline РCB153 & CB153 & & 6.66 & & \\
\hline PCB170 & CB170 & & 7.07 & & \\
\hline PCB180 & CB180 & & 6.93 & & \\
\hline PCB187/204 & CB187 & & 6.76 & CB204 & 7.61 \\
\hline Naphthalene & Nap & & 2.98 & NapxD8 & 2.99 \\
\hline Acenaphtene & Acne & & 3.57 & & \\
\hline Acenaphtylene & Acnle & & 3.21 & & \\
\hline Fluorene & Fle & 4.18 & 3.74 & FLExD10 & 3.70 \\
\hline Phenanthrene & PA & 4.57 & 4.05 & PAxD10 & 4.01 \\
\hline Anthracene & Ant & & 4.15 & & \\
\hline Fluoranthene & Flu & 5.22 & 4.57 & FluxD10 & 4.52 \\
\hline Pyrene & Pyr & & 4.63 & & \\
\hline Benz(a)anthracene & Baa & & 5.25 & & \\
\hline Chrysene & $\mathrm{Chr}$ & 5.86 & 5.19 & ChrxD12 & 5.16 \\
\hline Benz(e)Pyrene & $\mathrm{BeP}$ & 6.05 & 5.59 & BePxD12 & 5.55 \\
\hline Benz(a)Pyrene & $\mathrm{BaP}$ & & 5.66 & & \\
\hline Benz(ghi)-perylene & BghiP & & 6.00 & & \\
\hline Perylene & & 6.25 & & PexD12 & 5.40 \\
\hline Coronene & & & & CORxD12 & 6.39 \\
\hline Indeno(123 cd)pyrene ${ }^{\S}$ & & 6.58 & & & \\
\hline
\end{tabular}

\$ Abbreviation used in Annex 5 in reporting and at www.passivesampling.net

$\S$ Data From www.passivesampling.net, except Indeno(123 cd)pyrene from www.fws.gov/caribbean/ES/PDF/Contaminants/inden123.pdf 


\subsection{Calculation of free dissolved concentration}

The calculation of the free dissolved concentration of the organic substances are given below, using the performance reference compounds to correct for uptake rates in porewater (for sediments) and water, respectively.

\subsubsection{Sediment}

Calculation of the free dissolved concentration $\left(\mathrm{C}_{\mathrm{W}}\right)$ in an equilibrated system, as the sediment extraction bottles used in the PSTS, is done by:

$$
C_{W}=\frac{N_{R}-B l_{R}}{m_{R} K_{S W}}(1)
$$

in which $\mathrm{N}_{\mathrm{R}}$ is the amount (ng) of compound measured in the extract of the sheet/bottle; $\mathrm{Bl}_{\mathrm{R}}$ the procedural (solvent) blank (ng); $\mathrm{m}_{\mathrm{R}}$ the mass of passive sampling material $(\mathrm{kg})$ after exposure and $\mathrm{K}_{\mathrm{SW}}$ the material-water partition coefficient $(1 / \mathrm{kg})$, where the material used in the PSTS is silicone. The unit of the result obtained is in $\mathrm{ng} / \mathrm{l}$ but it is often more conveniently to express these results in $\mathrm{pg} / \mathrm{l}$, due to the low water solubility of the organic substances collected by the passive samplers.

The $\mathrm{K}_{\mathrm{Sw}}$ values were determined by RIKZ for use in the PSTS, and are applicable to silicone sheets.

For process QA and further information consult the draft guidelines on passivesampling.net or the OSPAR/ICES websites for updated guidelines.

\subsubsection{Water}

The procedure below is a rule-of-thumb procedure for samplers deployed in the free water masses. More extensive and statistically based procedures are given in literature.

\subsubsection{Step 1 - Screening of results}

Prior to calculating the sampling rate, the PRC data are screened. If the PRC-amount measured is less than 10 times the DL, the PRC is rejected. If the amount is more than half the amount of the reference, the PRC is also rejected. The remaining compounds are used to determine a sampling rate: $R_{S}$ in step 2 .

\subsubsection{Step 2 - Calculation of $\mathrm{R}_{\mathrm{s}}$}

The sampling rate can be calculated from the release of the PRCs that were spiked on the sampler before exposure. The release of compounds from the passive sampler (PS) follows first-order kinetics:

$$
N^{t}=N^{0} e^{-k_{e} t}(2)
$$


Where $\mathrm{N}^{0}$ is the mass of PRC measured in reference samplers that were not deployed, $\mathrm{N}^{\mathrm{t}}$ is the mass of PRC remaining in the PS after deployment, $\mathrm{k}_{\mathrm{e}}\left(\mathrm{d}^{-1}\right)$ is the first order dissipation constant that rules the release process, and $t$ the sampling time (d). After rewriting $\mathrm{k}_{\mathrm{e}}$ is calculated from:

$$
k_{e}=\frac{\ln \left(N^{t} / N^{0}\right)}{t}
$$

From eq. 3, the mass of the sampler $(\mathrm{m})(\mathrm{kg})$ and the $\mathrm{K}_{\mathrm{sw}}\left(K_{\mathrm{sw}}\right.$ from table 2.1) (litre/kg) the sampling rate $R_{S}$ (litre/d) is calculated through:

$$
R_{S}=k_{e} m K_{s w}=\frac{\ln \left(N^{t} / N^{0}\right)}{t} m K_{s w}
$$

$R_{S}$ values are calculated for all the PRCs that pass criteria of step 1 . From the $R_{S}$ values the median is used for further calculation of aqueous phase concentrations.

Note that this sort of calculation/use of PRC is only possible for reversible passive samplers like silicone sheets, where no reactions take place in the sampler. For DGT and POCIS samplers, chemical binding can occur that is not reversible in the water phase. It is also useful if some of the PRCs are retained in the sampler over the sampling period to check at what upper range of $\mathrm{K}_{\mathrm{sw}}$ the sampler was not working in the linear range. Only PRCs with 10-90\% remaining at the end of the sampling period are used to calculate the $\mathrm{R}_{\mathrm{S}}$. To that end a range of substances with $\mathrm{K}_{\mathrm{SW}}$ covering 4 to 6 is necessary.

\subsubsection{Step 3 - Estimate water concentration}

For estimation of the freely dissolved concentration $\left(\mathrm{C}_{\mathrm{W}}\right)$ in the water phase, the full uptake model that is valid for equilibrium and nonequilibrium situations is applied. The uptake is described by the following equation that includes the sampling rate $\left(\mathrm{R}_{\mathrm{S}}\right)$ estimate for that specific station and sampling period in the previous step:

$$
N^{t}=N^{0}\left(1-e^{-\frac{R_{s} t}{m K_{s w}}}\right)
$$

Here $\mathrm{N}^{\mathrm{t}}$ is the amount of compound (ng) in the sampler after deployment for time $t$ (days). The final amount absorbed at equilibrium $\left(\mathrm{N}^{\infty}\right)$ equals the equilibrium concentration $\mathrm{C}_{\mathrm{S}}^{\infty}$ times the mass of the sampler (m) in $\mathrm{kg} . \mathrm{C}_{\mathrm{S}}{ }^{\infty}$ is related to $\mathrm{C}_{\mathrm{W}}$ by the partition coefficient $K_{\mathrm{SW}}(\mathrm{l} / \mathrm{kg})$ and consequently:

$$
N^{\infty}=m C_{s}^{\infty}=m C_{W} K_{S W} \Rightarrow C_{W}=\frac{N^{\infty}}{K_{S W} m}(6)
$$


From eq. 5 and 6 the concentration in the water (CW) in ng/l, is given by:

$$
C_{W}=\frac{N^{t}}{m K_{S W}} \times \frac{1}{\left(1-e^{-\frac{R_{s} t}{m K_{s w}}}\right)}(7)
$$

In equilibrium the first term is dominating, and far from equilibrium the second term is dominating.

The OSPAR/ICES guideline for calculating $\mathrm{R}_{\mathrm{S}}$ is currently being revised, to take into account that the uptake rate is somewhat dependant on the $\mathrm{K}_{\mathrm{sw}}$, but this work is still in progress. 



\section{Sampling programme}

\subsection{Selection of stations}

The PSTS trial required two stations in each country/region, preferably with an expected difference of 10 times in PAH or PCB concentration in mussels from the two stations. Stations used for monitoring should be selected, and sediment and biota analysed for PAH and PCBs at the same positions. If possible, also spot samples of water should be included.

Monitoring stations in the Nordic countries were selected by individual institutions, based on their knowledge from the national monitoring programmes. A general overview of sampling within this NMR project is shown in figure 3.1, with details of sampling stations in the different countries given below.

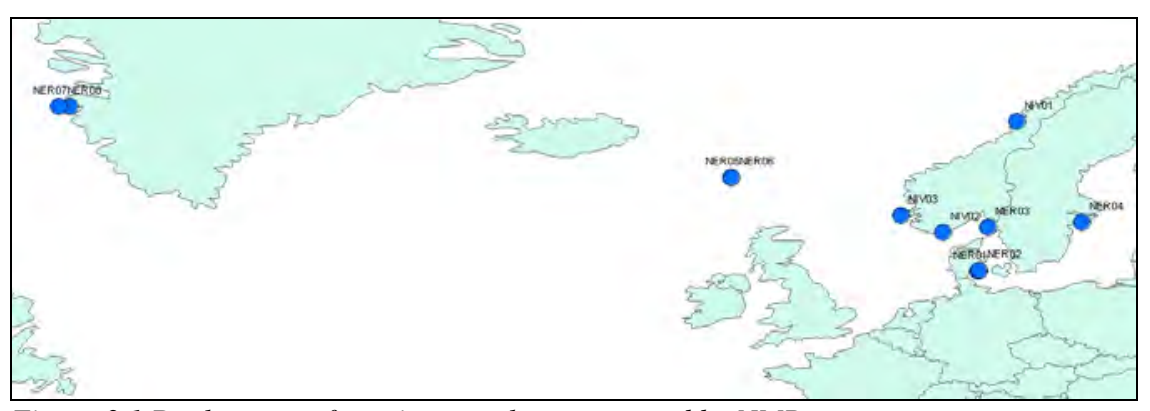

Figure 3.1 Deployment of passive samplers sponsored by NMR.

\subsection{Sampling stations for PSTS}

Positions of the Nordic sampling stations for PSTS are indicated in figure 3.1. Including the Greenlandic samples from 2007, the salinity range covers brackish waters of the Baltic to oceanic waters at the Faroe Islands and Greenland (7 to 34.8), and temperature range from 5 to 8 degrees. Pollution levels were from background/reference conditions at Greenland and the Faroe Islands to the highest measured in Europe in the Norwegian Fjords. 


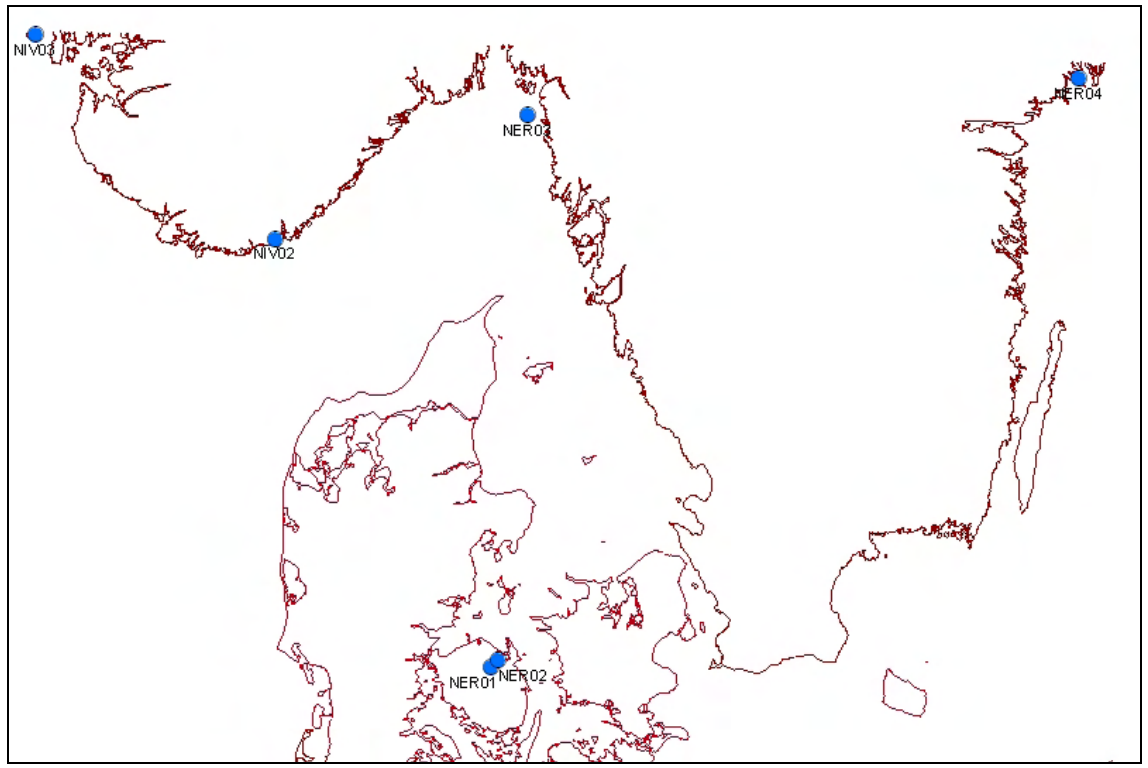

Figure 3.2 Placement of the central Nordic stations.

\subsubsection{Denmark}

Stations in the inner part and outer part of Odense Fjord were chosen, as national monitoring has indicated a gradient of PAH and PCBs in sediments and mussels. Odense Fjord is one of the fjords with the highest concentration of hazardous substances generally found in Denmark.

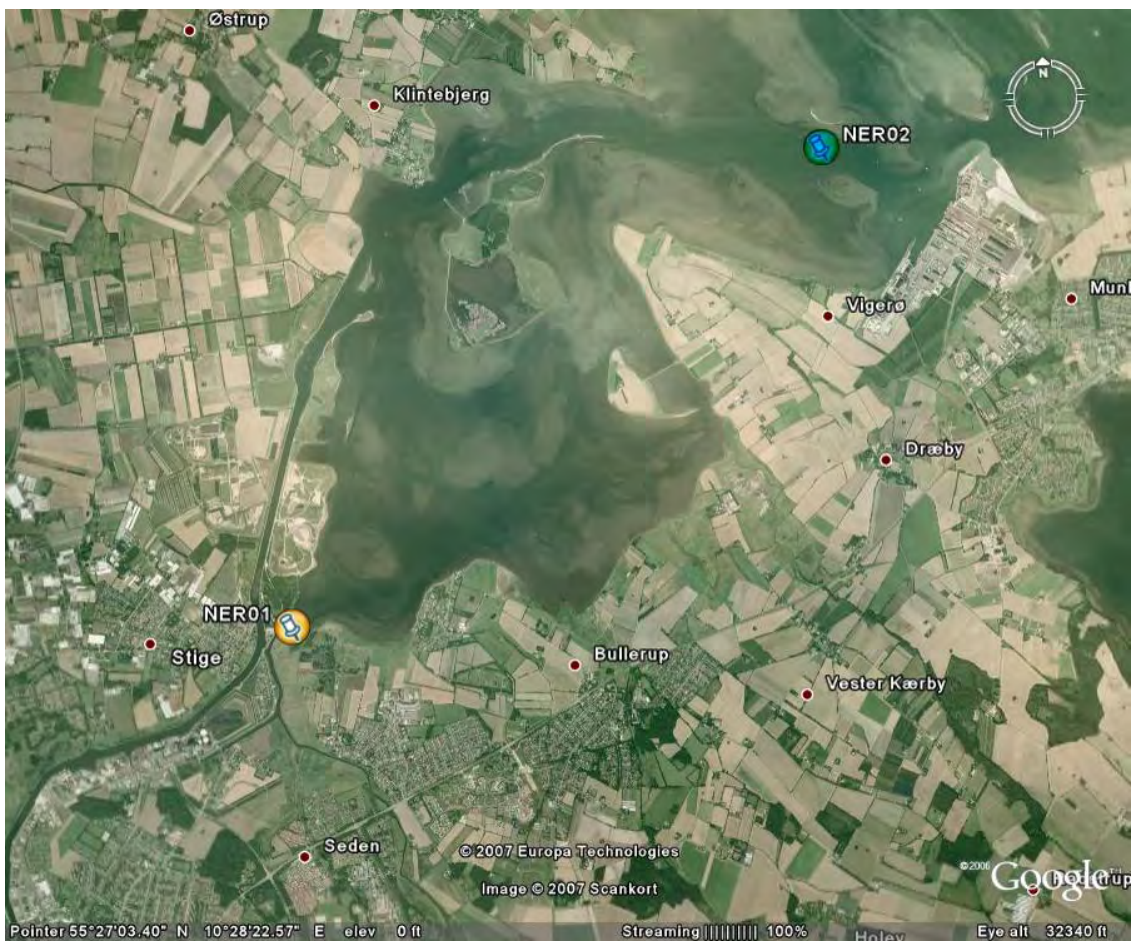

Figure 3.2a Close-up of Odense Fjord stations. 
Odense Fjord has one of the major Danish shipyards and the $3^{\text {rd }}$ largest city of Denmark with approximately 160 thousand inhabitants as sources.

Unfortunately, at the inner station NER01, only soft shell clams (Mya arenaria) were available. The uptake rate and biology of soft shell clams are not the same as blue mussels (Mytilus edulis) found at most other stations, including the outer Odense Fjord station NER02. This has to be taken into account when comparing the contaminant concentrations in the passive samplers with those in mussels. Previous results from the national monitoring programme did not show any significant difference between PCBs and PAHs in Mya and Mytilus in Odense Fjord.

\subsubsection{Sweden}

Askö: The station was chosen to represent a relatively uncontaminated area in the Baltic Proper. It is located close to the station Landsort, where on a yearly basis herring is sampled (since 1978, within the national monitoring programme), thus it is possible to compare the results from the passive sampling survey with the analytical results in herring

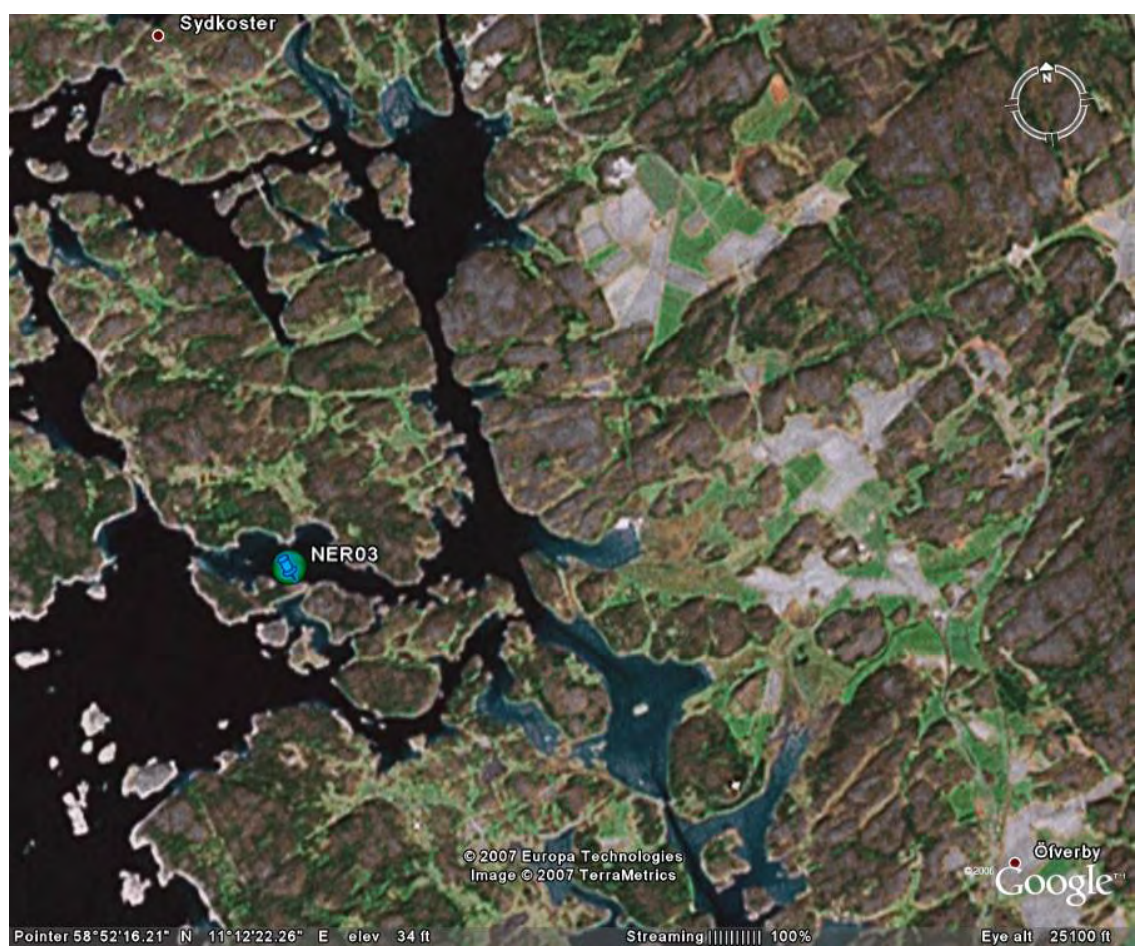

Figure 3.2b Close-up of Tjärnö station.

Tjärnö: The station was chosen to represent a relatively uncontaminated area in the Skagerrak at the Swedish west coast, where levels of PCBs usually are about $50 \%$ lower than the levels in the Baltic Proper. Tjärnö is located close to the station Väderöarna, where on a yearly basis herring, eelpout and blue mussel are sampled (since the 1980s, within the national monitoring programme), which enables a comparison between the results 
from the passive sampling survey and the analytical results from the other matrices mentioned.

\subsubsection{The Faroe Islands}

The passive samplers were deployed at two stations on the Faroe Islands, one inside the harbour of Tórshavn (NER06) and one just outside (NER05), near the entrance to the harbour. Both passive samplers were connected with chains to buoys that are permanently anchored at the sites, along with cages with mussels. The stations are not regular monitoring stations but have been used in investigations of the pollution status of the harbour, with NER05 then as reference station. Water samples were taken at both stations when the passive samplers and mussels were exposed, and sediment samples were simultaneously taken at NER05 (it was not possible to get sediment samples at NER06).

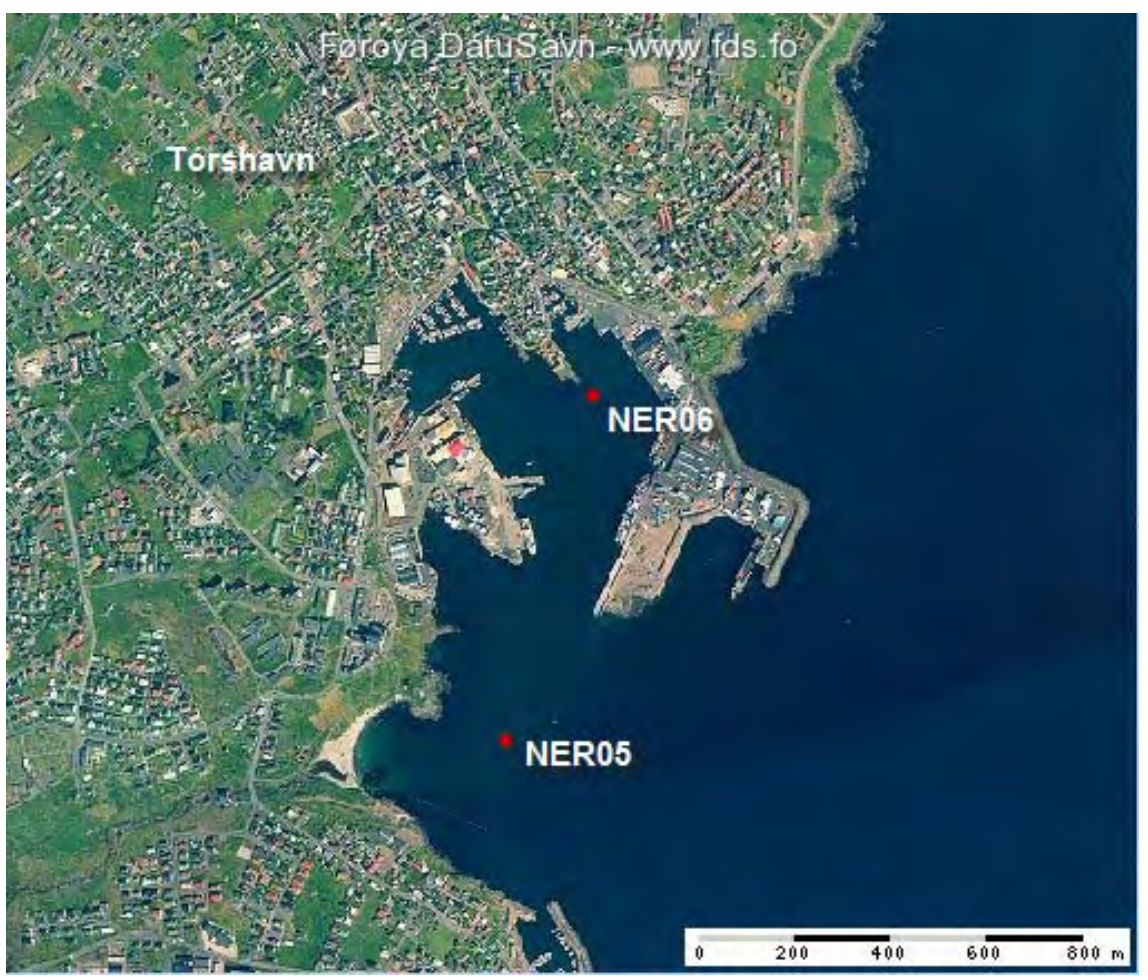

Figure 3.2c Close-up of stations at the Faroe Islands.

\subsubsection{Norway}

The northernmost site was the Vefsnfjord situated in the northern part of Norway (NIV02). This is not a very densely populated area. However, an aluminium plant is situated in the inner part of the fjord. This facility used to discharge significant amounts of PAHs into fjord waters, however, improvements in the technology used in this industrial plant in 2002 resulted in reductions in the amount of PAH discharge. 
The next site moving southwards was the site in Karmsund (NIV03). The Karmsund is a coastal sound in the south-west part of Norway. The site for deployment of the passive samplers was close to an effluent discharge point from an aluminium plant. Significant discharges of PAHs are still occurring at this plant.

The southernmost site selected in Norwegian waters was in the Kristiansand Fjord (NIV01). The passive samplers were deployed in a small harbour for leisure boats. There is also a small shipyard in the area.

\subsubsection{Greenland}

Samples from Greenland were placed at the inlet of Ulkebugten (NER07) at Sisimiut, the second largest city of Greenland with 5,000 inhabitants. There are no wastewater treatment plants, and the harbour suffers reoccurring oilspills. The reference station was placed at Frederiks VII Island (NER08), some kilometres outside the Ulkebugt, with no inhabitants, and only accessible at high tide. The difference between high and low tide is 2-5 m. Mussels were collected at minimum sea level at both stations, with samplers hanging $1 \mathrm{~m}$ below the surface at water depths of at least 7 $\mathrm{m}$ at high tide. At both stations blue mussels was sampled, but not sediments as there was only a limited number of silicone-coated bottles available and these had been used for the Nordic stations.

Close-up maps of sampling stations of Denmark, the Faroe Islands and Sweden are given in figures 3.2a-c.

\subsection{Passive sampler handling}

Three jars with 6 sheets each were dispatched to the participants. Jars were stored in a freezer until exposure. Tweezers were required for mounting the sheets and a clean working place to sort the sheets on: either in stainless steel or a place covered with pre-baked $\left(450^{\circ} \mathrm{C}\right)$ aluminium foil. Samplers were then mounted onto the deployment cages. Date and time of deployment and retrieval were noted. Salinity, water and air temperature were also recorded and measurements of SPM levels were conducted by filtration. Following retrieval, samplers were stored back in the jars and in the freezer until extraction and analysis.

\subsubsection{Passive sampler extraction and analysis}

The 6 sheets were extracted using a Soxhlet apparatus with methanol for 8 hours. A procedural blank was done in the same way, but without sheets. Another method to extract sheets is cold extraction procedure, where 150 $\mathrm{ml}$ methanol is shaken gently overnight with the sheets. This is repeated with fresh methanol after eight hours. Internal standard were added at this 
stage. Cleanup of the extract was conducted with $\mathrm{C}_{18}$ bounded silica. This ensures that no oligomers are present in the extract. The extract was reduced to $2 \mathrm{ml}$. The column (300-500 $\mathrm{mg} \mathrm{C}_{18}$ bounded silica) was prerinsed with $6-10 \mathrm{ml}$ methanol/acetonitrile. The extract is then transferred to the column and eluted with 6-10 ml methanol/acetonitrile. Coronene is the last eluting compound. Azeotropic solvent transfer of methanol/acetonitrile to hexane was conducted by concentrating the extract obtained as above to $2 \mathrm{ml}$ and then adding $10 \mathrm{ml}$ hexane for each $\mathrm{ml}$ of methanol/acetonitrile. The mixture was reduced to $<2 \mathrm{ml}$ on a water bath. Analysis of the extracts was conducted by GC/MS following similar procedures as described below for biota and sediment samples.

\subsubsection{Pore water measurements}

Three one-litre glass bottles were used for sediments from each sampling station. The bottles are made of aluminium foil lined caps and the inside walls of the bottles are coated with about $300 \mathrm{mg}$ PDMS spiked with PRC. Bottles were stored in the dark and in a freezer until use.

Sediment samples were collected according to OSPAR guidelines. At least $3 \mathrm{~kg}$ were collected in a glass or stainless steel container and homogenised.

Sub-sampling was done for dry weight determination, for the determination of total concentrations of the target compounds in the sediment, as well as for the total organic carbon content. Two bottles were filled with the sediment up to 50 to $60 \%$ and the amount recorded by weighing the bottle with sediment. A wide-opening stainless steel or glass funnel was used to add the sediment to the bottles.

Bottles were purged with $\mathrm{N}_{2}$ to remove oxygen before closing the bottles. Bottles were shaken at $100 \mathrm{rpm}$ for at least 20 days in the dark at room temperature $\left(20^{\circ} \mathrm{C}\right)$.

After the equilibration period, the bottles were emptied and vigorously shaken with portions of 50-100 ml milli-Q water to remove all sediment. Bottles were drained upside down on a tissue. Bottles were closed and stored in a freezer until analysis. The bottles were extracted twice with 50 $\mathrm{ml}$ methanol or methanol + acetonitrile $(1+3 \mathrm{vol} . / \mathrm{vol}$. $)$. Bottles were then shaken for four hours. Procedural blanks were used. Extracts were processed and analysed in a similar way as the sheets.

\subsection{Extraction and analysis for biota and sediment}

Biota samples were homogenised, using an ultra Turrax ${ }^{\mathrm{TM}}$ (Ika-Werke

$\mathrm{GmbH}$, Staufen, Germany), internal standards added (200 ng each of naphthalene-d8, acenaphthene-d8, phenanthrene-d10, chrysene-d12, perylene d12, and anthracene d10) and saponified. The PAHs were ex- 
tracted with $n$-pentane and dried over sodium sulphate. The extraction volume was reduced, solvent exchanged to dichloromethane, and the extracts were cleaned by gel permeation chromatography (GPC) and solvent exchanged to cyclohexane. If necessary, the samples were further cleaned by dimethylformamide partitioning and silica column elution. Extracts were analysed by gas chromatography and mass spectrometry (GC/MS) (Agilent GC 6890 with MSD 5973; Agilent Technologies, Wilmington, DE, USA). The MS detector was operated in selected ion monitoring mode (SIM), and the analyte concentrations in the standard solutions were in the range $5-1000 \mathrm{ng} / \mu \mathrm{l}$. The GC was equipped with a $30 \mathrm{~m}$ J\&W DB-5MS (stationary phase of 5\% phenyl polysoxilane) column $(0.25 \mathrm{~mm}$ i.d. and $0.25 \mu \mathrm{m}$ film thickness), and an inlet operated in the split less mode. The initial column temperature was $60^{\circ} \mathrm{C}$, which after 2 min was raised to $250^{\circ} \mathrm{C}$ at a rate of $7^{\circ} \mathrm{C} / \mathrm{min}$ and thereafter raised to $310^{\circ} \mathrm{C}$ at a rate of $15^{\circ} \mathrm{C} / \mathrm{min}$. The injector temperature was $300^{\circ} \mathrm{C}$, the transfer line temperature $280^{\circ} \mathrm{C}$ and the MS source temperature $230^{\circ} \mathrm{C}$. The column flow rate was $1.2 \mathrm{ml} / \mathrm{min}$. Quantification of individual components was performed by using the internal standard method.

The sediment samples were homogenised and internal standards added. The PAHs were then extracted with dichloromethane and cyclohexane $(1: 1, \mathrm{vol} / \mathrm{vol})$ by Accelerated Solvent Extraction (ASE) (Dionex ASE-200; Dionex Corp., Sunnyvale, CA, USA) at a temperature of $100^{\circ} \mathrm{C}$ and a pressure of $2000 \mathrm{psi}$. The further cleaning of the extracts and GC/MS analysis was as described above. 



\section{Results}

\subsection{Reporting of the PSTS}

The results from the sampling trial on water phase (silicone rubber, mussels) and sediment phase (coated glass, sediment samples and worms) were reported to RIKZ, mainly within the deadline. Reporting of PCB and PAHs in mussels from the Swedish test sites was delayed until 2008, and Greenland was only sampled in August 2007, so results from this location was first made available to the steering group at the beginning of 2008. The other results were presented by the PSTS steering group at the ICES Annual Science Conference 2007 (17-21 September) in session J. Results from the Nordic samples (except mussels from Sweden) were included at this point, but only results from calculations on water concentration through the use of PRC and comparisons on reference and national laboratories were presented.

The final results reported to the PSTS steering group can be found in Annex 5 in this report. Manuscripts from the ASC are still in the process of being finished, and this work is overseen by the steering committee of the PSTS. Nordic results have been published in connection with another survey using passive samplers in Bossi (2009) (in Danish).

\subsection{Water phase results}

The passive sampler of choice for PSTS was silicone rubber. Results from the national laboratory was only available for 3 samplers (NER01, NER05 and NER06), as a mistake in sample handling resulted in contamination of the NER02 sample at the laboratory in NIVA, and for NER03 and 04 only one set of silicone rubbers was deployed, which was sent to the reference laboratory at RIKZ. Remaining silicone sheets were instead deployed at Greenland in 2007, and only analysed at the reference laboratory. The analysis of PCBs in the silicone sheets was hindered by the method used at the national laboratory, due to interferences in the chromatograms with the PCB internal standards, disallowing the calculation of the concentration of PCBs in the sheets. Unfortunately, this was not discovered until after the extraction of all sheets, so no PCB results are available from the national laboratory. Further use of silicone sheets with the set of PRCs used here would demand some method development and checking to find an internal standard (or standards) without interfering peaks. 
As an example of calculation, fluoranthene-D10 for NER06 is shown below:

$\mathrm{N}^{\mathrm{t}}=260, \mathrm{~N}^{0}=391: 67 \%$ is remaining in the silicone sheet after 41 days (see figure 4.1). Offload rate per hour can be calculated from equation (3):

$$
k_{e}=\frac{\ln (260 / 391)}{41 * 24}=0.000415
$$

The Log $K_{\text {ow }}$ for fluoranthene is 5.22 and $K_{\mathrm{SW}}$ for fluoranthene- $\mathrm{d}_{10}$ has been estimated as 4.52 (table 2.1), so $\mathrm{R}_{\mathrm{s}}$ can be determined from equation 4 (see also figure 4.2 ):

$$
R_{S}=k_{e} m K_{s w}=0.000415 \frac{1}{h} \bullet 0.021 \mathrm{~kg} \bullet 10^{5.22} \approx 0.27 \frac{L}{h} \approx 6,9 \frac{L}{\text { day }}
$$

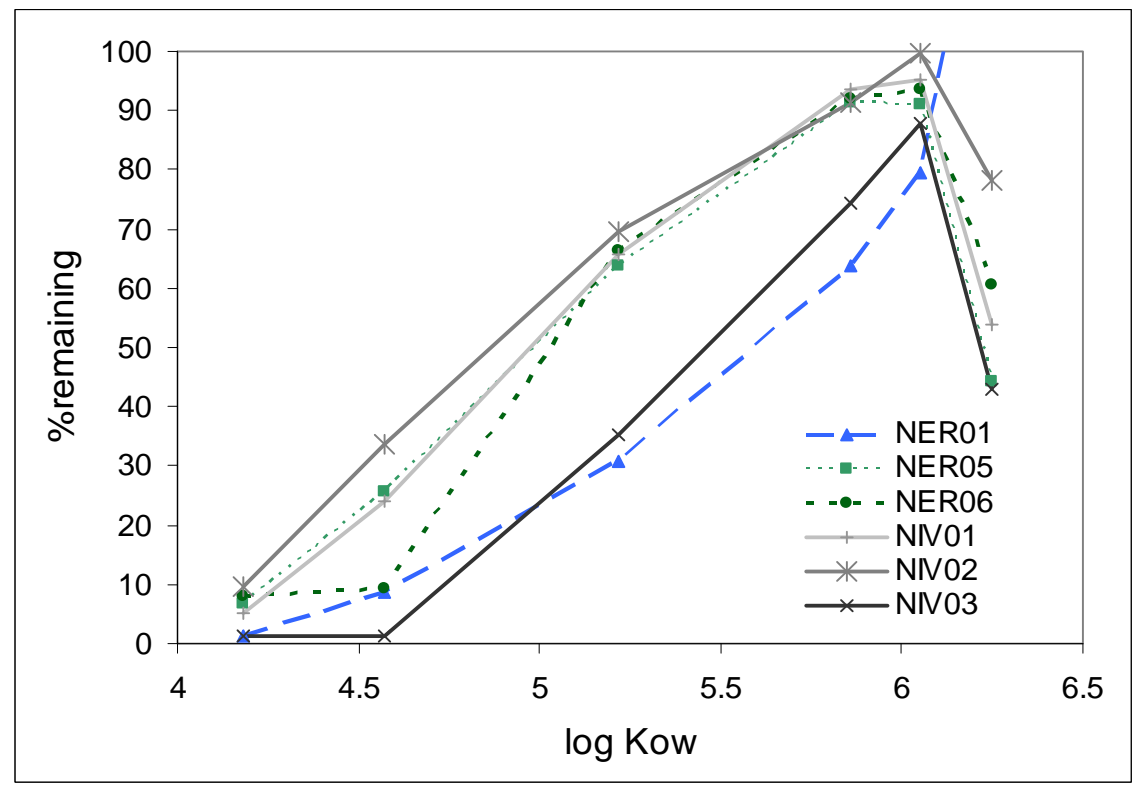

Figure 4.1 Depletion of PRCs according to $K_{\text {ow }}$, phenanthrene- $D^{10}$ to perylene $D^{12}$ shown, naphthalene always below detection limit (dl). For NIV03 fluoranthene- $D^{10}$ and phenanthrene- $D^{10}$ was below dl as well.

Table 4.1 Median sampling rates as litre per day, calculated from PAH-PRCs with indication of relative standard deviation on the calculated $\mathbf{R}_{\mathbf{s}}$.

\begin{tabular}{lll}
\hline Station & Median Rs (I/day) - & Range Rs [extreme values] \\
\hline NER01 $^{\$}$ & $26(48 \%)$ & $13-41$ \\
NER05 & $7.4(5 \%)$ & $6.8-7.6[17,104]$ \\
NER06 & $9.4(35 \%)$ & $6.2-12[64]$ \\
NIV01 & $7.5(22 \%)$ & $4.8-9.2[80]$ \\
NIV02 & $6.1(6 \%)$ & $4.8-9.2[0.7,32]$ \\
NIV03 & $23(11 \%)$ & $18-23[108]$ \\
\hline
\end{tabular}

\$: NER01 concentrations multiplied by 3 to simulate 3 sheets as in all other cases. 
For calculation of Rs, spiked PRCs, namely PCBs and d-PAHs were available for the 6 samples NER01, NER05, NER06 and NIV01-03. Calculations of Rs for these, based on the PSTS manual, are shown in table 4.1. The depletion (figure 4.1) of the PRCs was 5-94\%, depending on the $K_{\text {ow }}$ of the PAHs, so that naphthalene in all samples were totally depleted ( $<10 \mathrm{ng}$ in the sheets), fluoranthene contained 3-9\% of the original amount (except in NIV03), where both fluoranthene and phenanthrene were $<10 \mathrm{ng}$ ).

The calculated median sampling rates (table 4.1) indicate that sites NER01 and NIV03 have been in more turbulent waters than the rest, with sampling rates a factor of $2-3$ above the other samplers. The $\mathrm{R}_{\mathrm{s}}$ calculated varies with the $K_{o w}$, as indicated in figure 4.2, but except for NER01 are fairly stable up to a $K_{o w}$ of 6 (Benzo(e)pyrene-d12). As there was only $7 \mathrm{~g}$ of sampling sheet available for NER01 (compared to $21 \mathrm{~g}$ for the other samples), concentrations in ng of sheets was multiplied by 3 , so that all stations were based on approx. $21 \mathrm{~g}$ of silicone sheet material. The uncertainty of the $R_{s}$ was estimated by calculating the relative standard deviation between the values of PRC with $10-90 \%$ retention. The range of the $R_{\mathrm{s}}$ values found is also given in table 4.1.

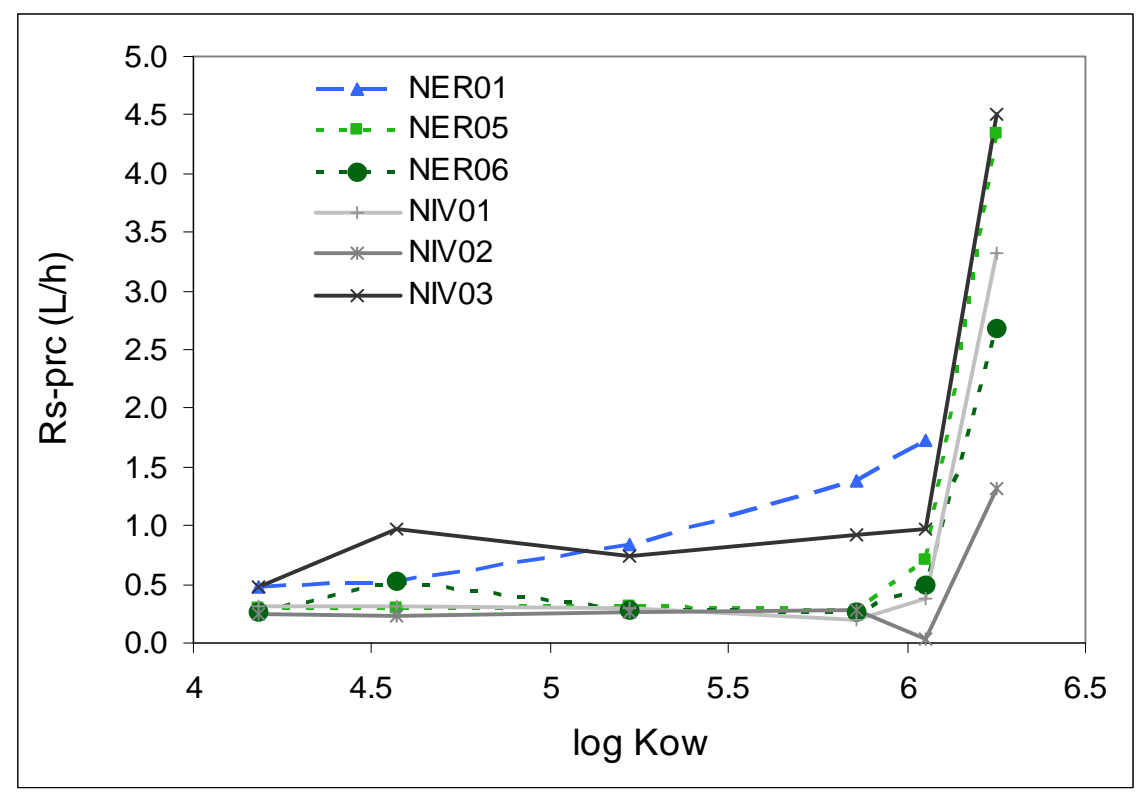

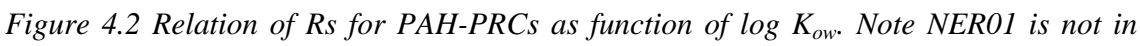
equilibrium, whereas most others are equilibrated up to around $K_{\text {ow }} 6$ (benzo(e)pyrene), and the final point for coronene is know to behave differently than the other PAHs

The concentration of PAH in the silicone sheets (figure 4.3) indicates a range of 10-1000 times for the lowest to the highest concentration found, suggesting that the station selection lives up to the prerequisite of spanning a factor of 10 between highest and lowest concentrations. The pattern for naphthalene at stations NER05 and NER06 indicates that the PAHs in water from the inner harbour at the Faroe Islands is mainly due to oil spills. 
The high levels of mid-range and high $K_{\mathrm{OW}}$ PAHs in NIV03 indicate that there is a tar-related pollution affecting the water phase. This was expected, and is one of the reason for including this station in the trial.

The concentrations in the sheets were recalculated to $\mathrm{pg} / \mathrm{l}$ in the water phase, and the results are shown in figure 4.4. Note the high $R_{s}$ values of NER01 and NIV03 decrease the original trend of high concentrations in the samplers, but still indicate a factor of 100-500 between the cleanest and most contaminated sites in this survey.

Finally, the concentration of PAH in water can be calculated from that in the sampler using the $K_{\mathrm{Sw}}$ of 4.57 for fluoranthene and equation 7 :

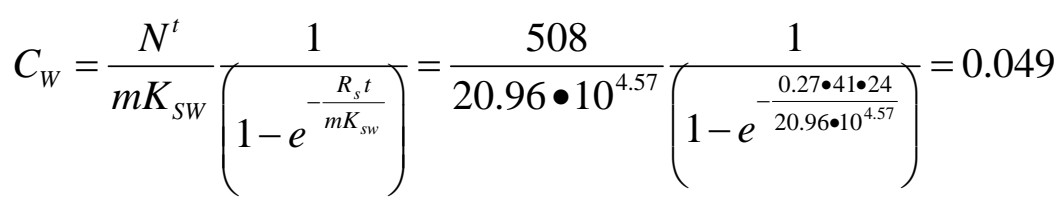

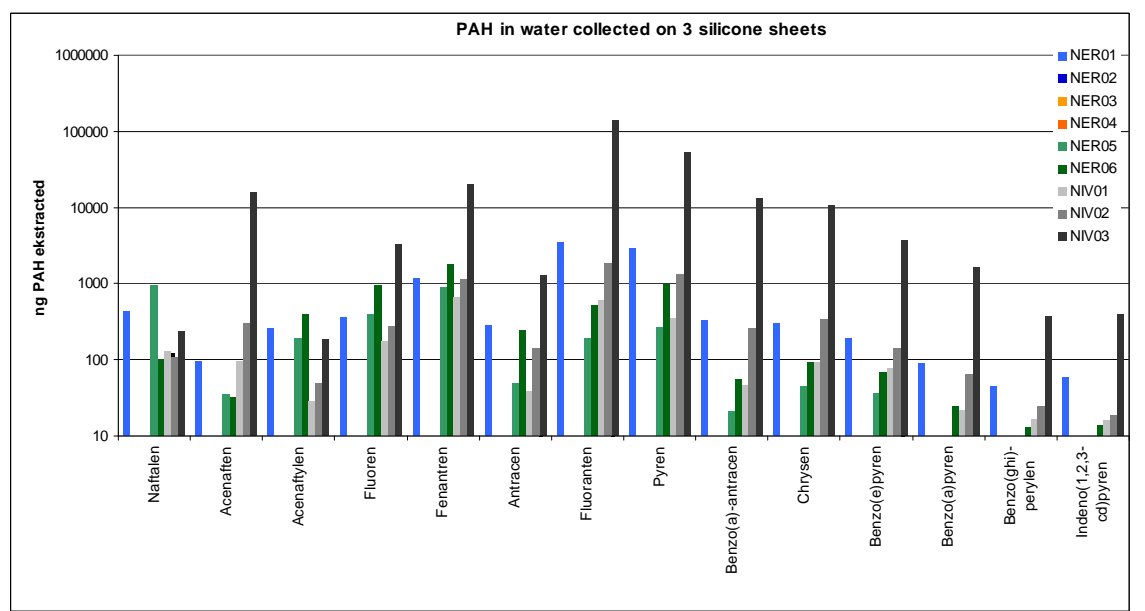

Figure $4.3 \mathrm{ng}$ PAHs in 3 silicone sheets exposed to the water column for 41 to 66 days in 6 different places (no results available for NER02-04).

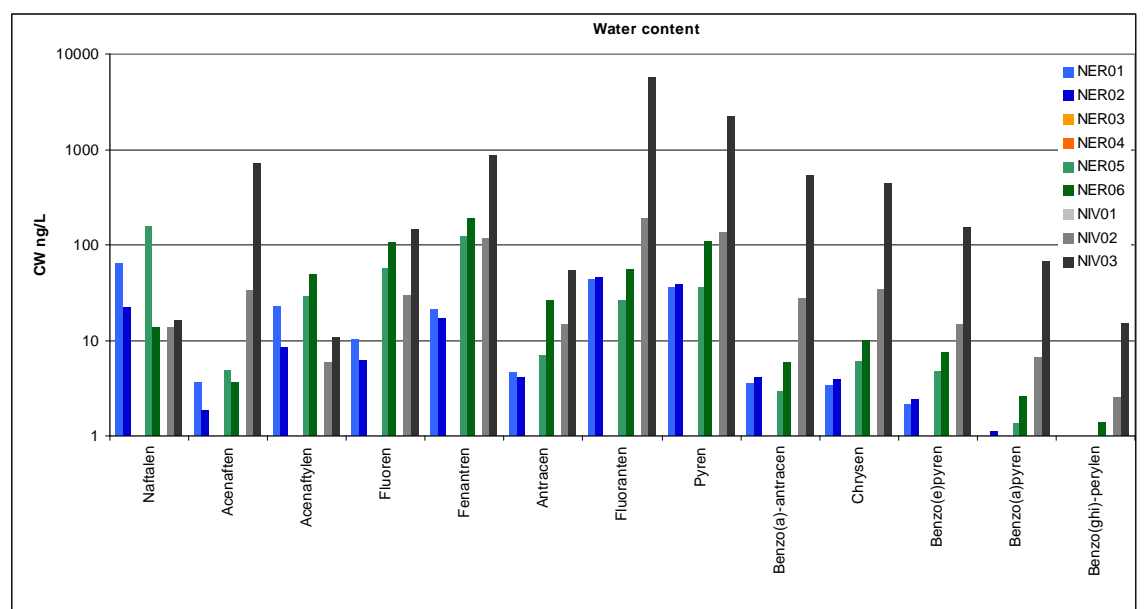

Figure 4.4 Calculated free water concentration from passive samplers at the different stations (from equation 7 in chapter 2). 


\subsection{Results from measurements in sediment pore waters}

The method of choice for PSTS was silicone rubber, coated on the wall of a bottle. As many of the sediment samples were relatively sandy, a major portion of the silicone rubber was lost by the movement of the sediment grains, but enough was left to carry out the analysis of four sediment bottles. For one other sediment bottle, only one sample was prepared, and this was analysed by the reference laboratory.

Results for NER01-03, NER05 and NIV01-03 are available. For NER04, only one bottle was available, so the passive sampler was only analysed by the reference laboratory. The sediments were analysed for PAH and PCBs by NIVA for Greenland, the Faroe Islands and Norway and by the national laboratories in all sediment samples, NER01-NER05 and NIV01-03.

The results covered two orders of magnitude, from the detection limit of approximately $10 \mathrm{ng}$ to several $1000 \mathrm{ng}$ of benzo(e)pyrene. In general, the NIVA samples were much higher (by a factor of 2 to 100) than those from NERI, and the pattern was also different, with an increasing trend up to benzo(e)pyren. For the NERI samples, the highest concentrations were observed in fluoranthene and pyrene, and with detectable amounts of naphthalene in NER01 and NER05. The increased concentration in NIV01-03 of higher $K_{o w}$ PAHs indicates a release of these PAHs from the sediment, especially when compared with the water phase sheets, where the pattern follows the NER samples, with maximum around fluoranthene/pyrene.

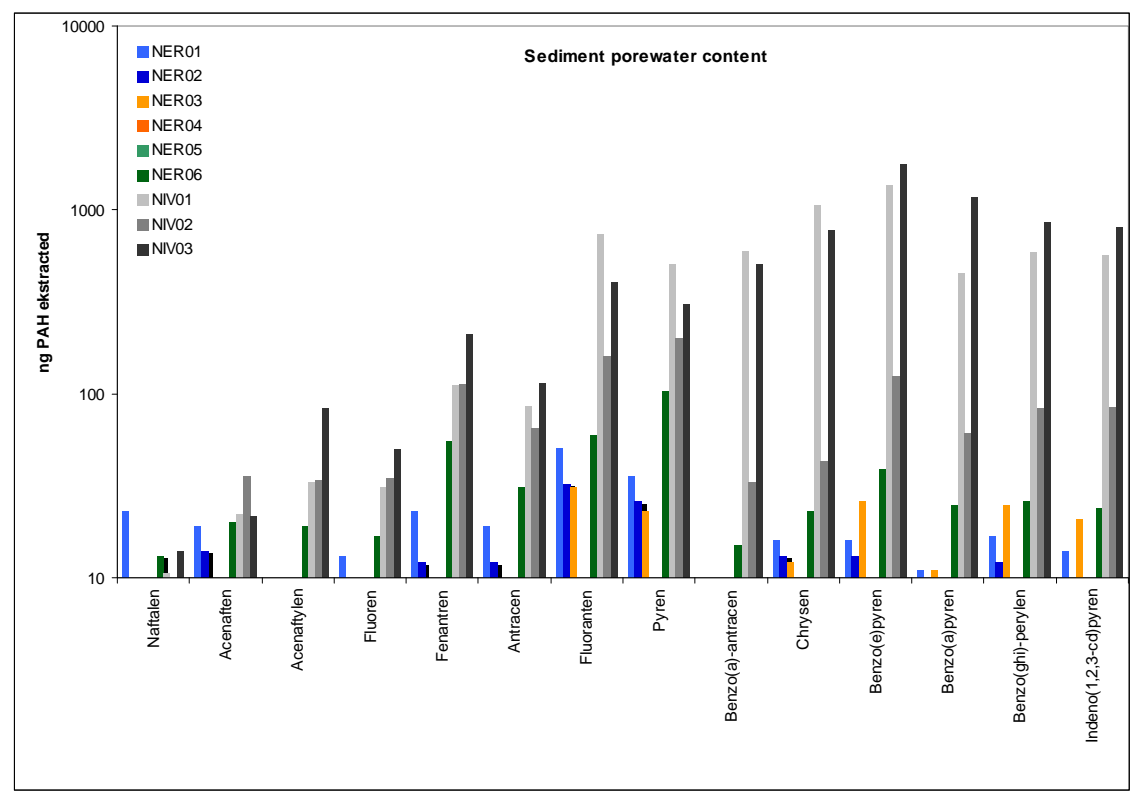

Figure $4.5 \mathrm{ng}$ PAH found in silicone-covered bottles, rotated for 20 days with sediment. 


\subsubsection{Comparison of passive sampler results for water and pore water}

Comparing contaminant activity/concentration in pore water with that in the overlying water phase provides a possibility to judge whether the sediment acts as a sink or source of contaminants to the water phase. In general, if pore water concentrations are higher than those in the overlying water column, the sediment can be assumed to act as a source. However, in the case of lower concentrations in pore water than in the overlying water, the sediment can be assumed to be a sink for contaminants. For the samples where both pore water and water phase concentrations are available, in most areas the sediment will act as a sink (figure 4.6), but at NIV01 (Mosjon Fjord) it acted as a source for most PAHs. This is validated by the results from the reference laboratory (see section 4.7).

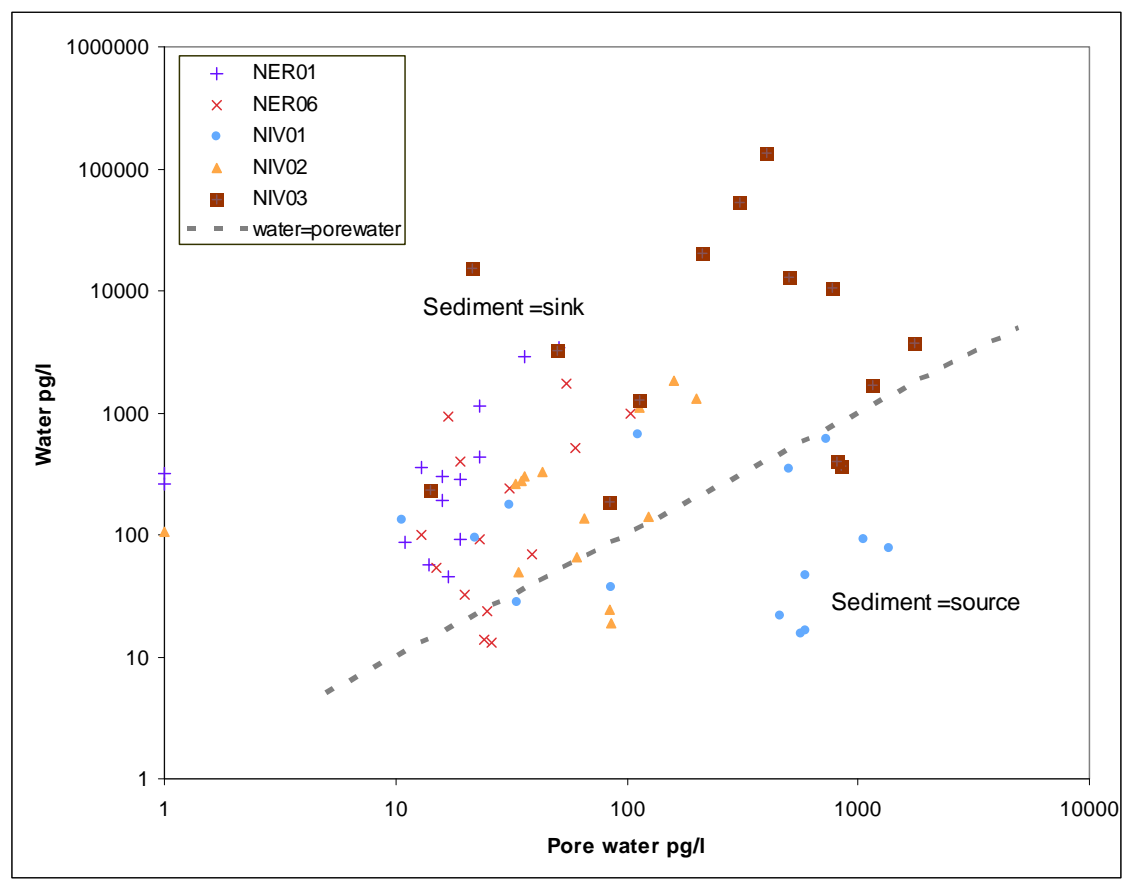

Figure 4.6 Comparison of pore water concentrations with water concentrations measured by passive samplers. Samples above the line indicate that sediment acts as a sink for the PAHs, below that it acts as a source. PAHs close to the line are in equilibrium between pore water and the overlying water column.

To investigate further for which PAHs the sediments were acting as sink or sources, ratios were compared for each station and individual $\mathrm{PAH}$ in figure 4.7. Equilibrium is expected if $\mathrm{C}_{\text {water }}=\mathrm{C}_{\text {pore water, }}$ the $\mathrm{Y}=\mathrm{X}$ line in figure 4.7. This indicates that the most water insoluble PAHs (high $K_{\text {ow }}$ ) benzo(ghi)perylene and indeno(123-cd)pyrene were highest in pore water except for NER01, and for NIV01 only 4 PAHs were below the equilibrium line (naphthalene, acenaphthene, fluorene and phenanthrene). 


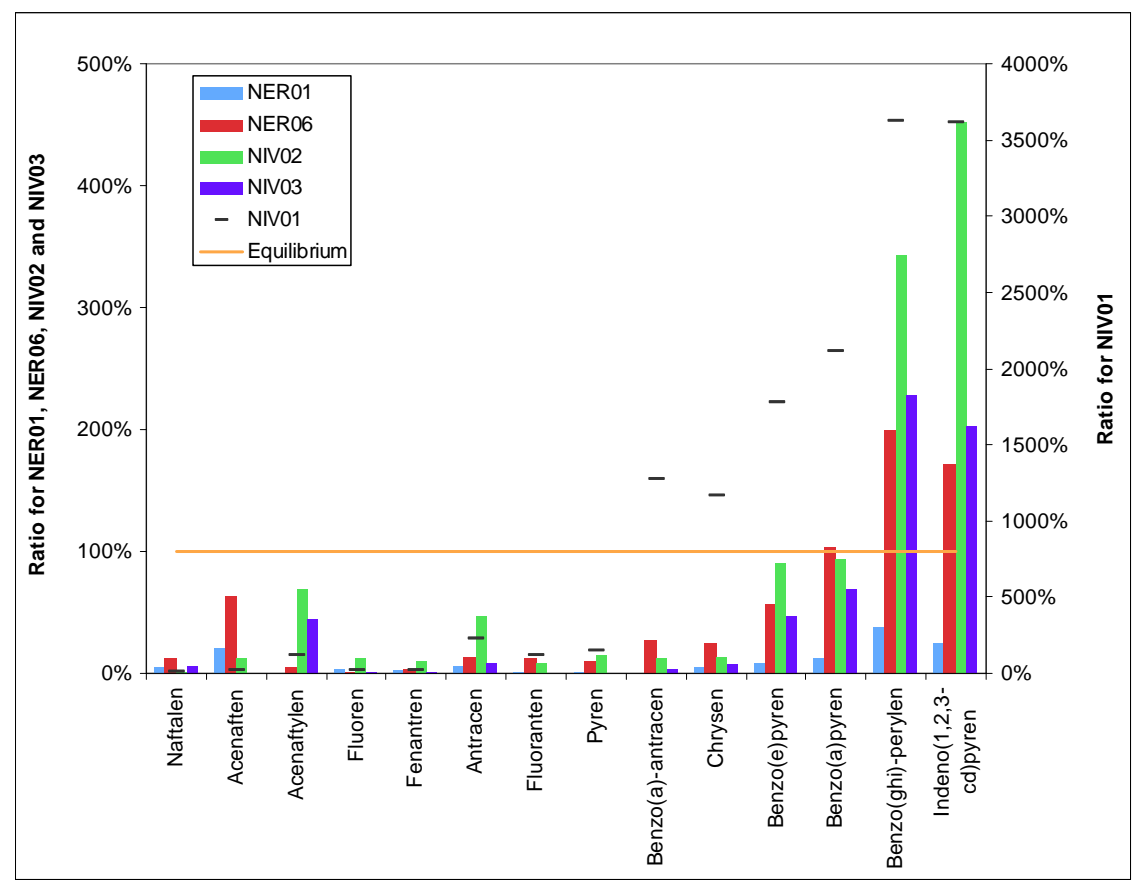

Figure 4.7 Ratio of pore water to water concentrations measured by passive samplers, by stations and PAHs. Notice NIV01 on different scale, equilibrium (100\%) is valid for NER01, NER06, NIV02 and NIV03 only.

\subsection{Results from the work with mussel and sediments}

Biota and sediments from Denmark, Norway and Sweden were analysed by the national laboratories as part of national monitoring programmes. Results are available in the results sheets in Annex 5. Concentration levels are presented in figures 4.8 and 4.9 .

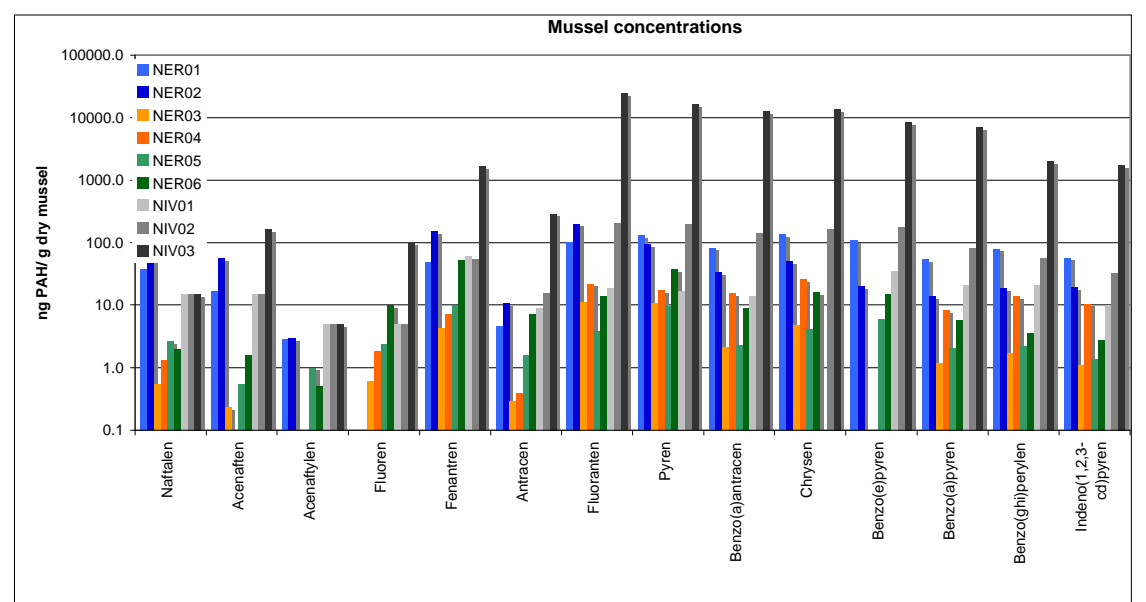

Figure 4.8 Concentration range for the different PAHs and areas. For most stations, concentrations span 2-3 decades, testing the passive sampling sheets to its limits. 


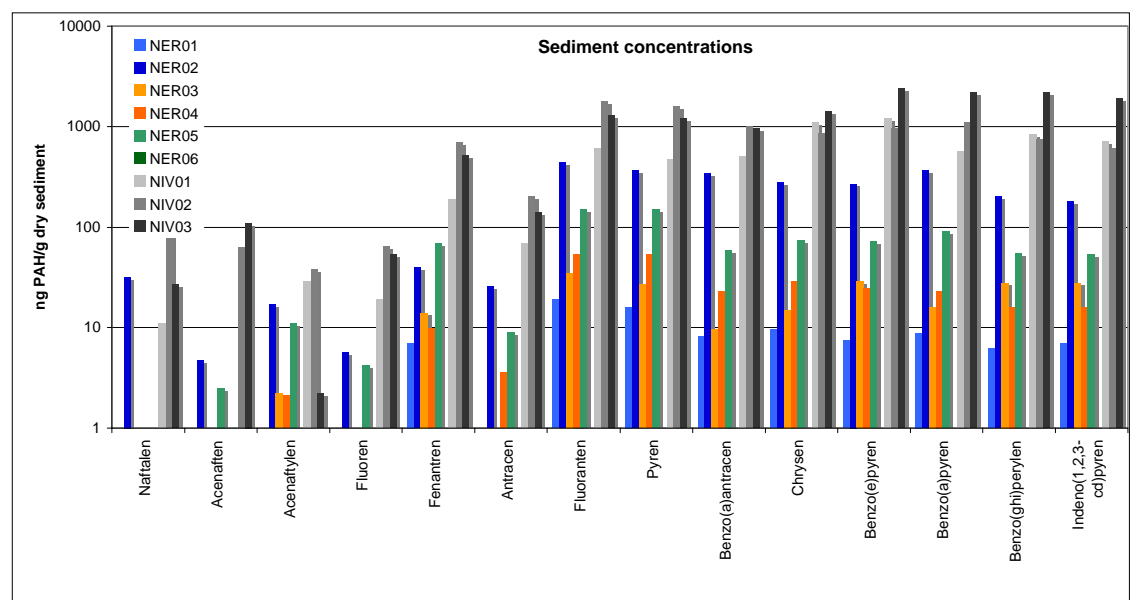

Figure 4.9 Concentration range for the different PAHs and areas in sediments. As for mussels, the concentration range spans 2-3 decades, suggesting that the data set was appropriate as a test set for passive samplers.

\subsection{Comparison of passive samplers and mussel/sediment samples}

The calculated concentrations in the water phase of PAHs were compared to the concentration in mussel tissues. For station NER01, the mussel is soft shell clam (Mya arenaria), for station NER05 and NER06 blue mussels (Mytilus edulis).

Correlations between mussel/water ratios and total sediment/pore water ratios with $\log K_{\mathrm{OW}}$ are shown in figures 4.10 and 4.11. For sediments though, naphthalene was an outlier. This is as expected since the more lipophilic compounds, the higher BCF is expected as the solubility in water decreases.

The soft shell clams of NER01 have the same ratio of concentrations in mussel and water as the blue mussels from the other sites, except fluorene at $\log K_{\text {ow }} 3.74$, which was not found in the clams. This could be taken as an indication that the uptake rates of soft shell clams and blue mussels are the same for substances with $\log K_{o w}>3$ as PAHs. 


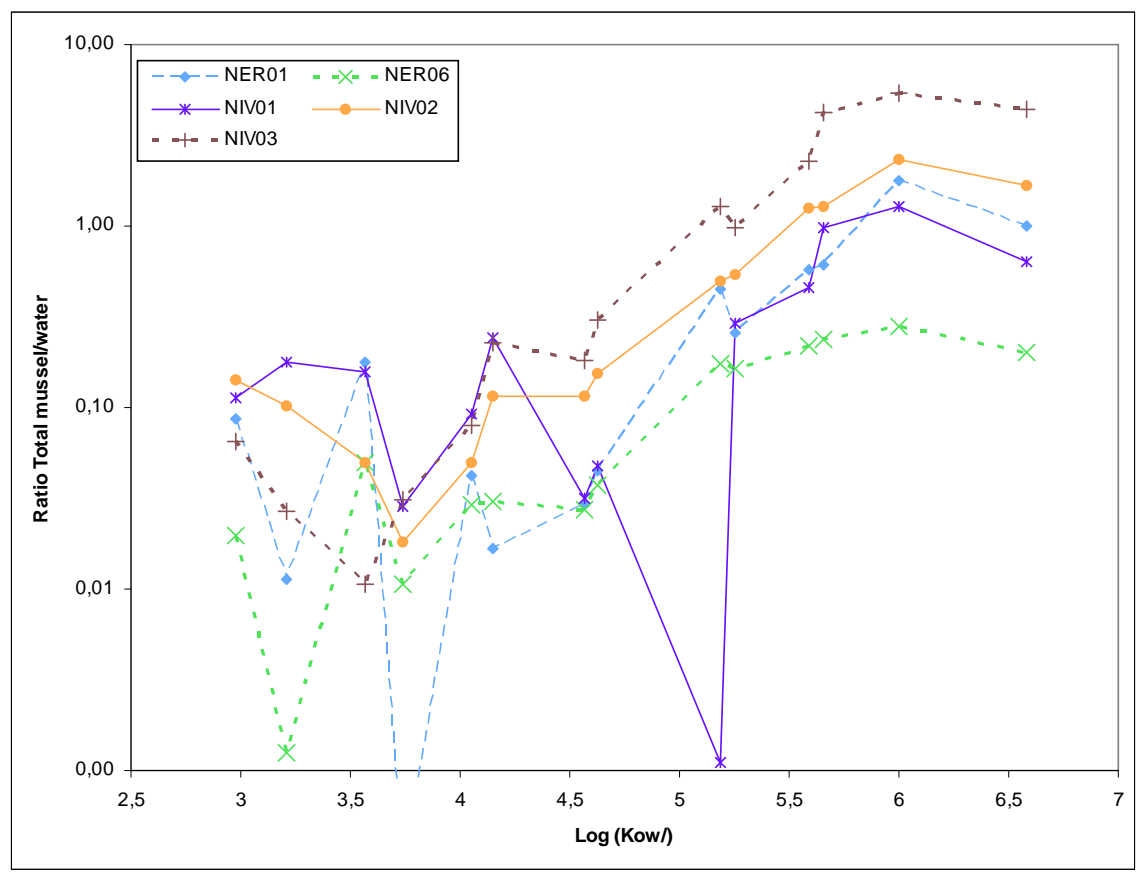

Figure 4.10 Bioconcentration factors, mussel concentrations $(\mathrm{mg} / \mathrm{kg})$ to water concentration measured with passive sampler ( $\mathrm{ng} / \mathrm{l})$, against $\log K_{o w}$. Note the ratio increases with the PAH retention time $(K d)$. The difference between lowest and highest is a factor of 15 (except 3 outliers around 0.001, note logarithmic scale).

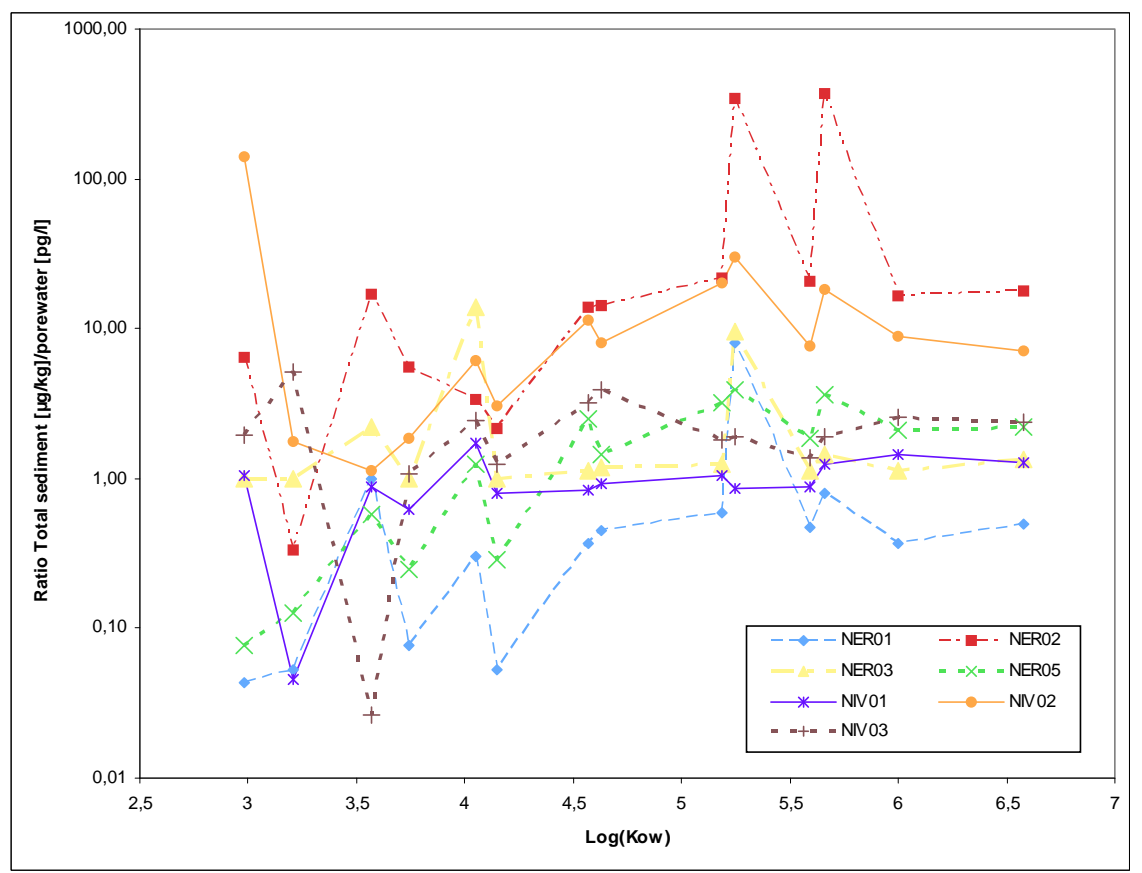

Figure 4.11 The ratio of total sediment concentration $(\mu \mathrm{g} / \mathrm{kg})$ to pore water concentration

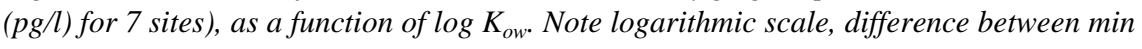
and max is up to a factor of 500 .

The passive sampling measurements in "old" sediments with high concentrations did not exhibit in the expected pore water concentrations, 
resulting in a high ratio of pore water to sediment (e.g. NER02 and NIV02 in figure 4.9). The interpretation is that for sediments presenting "old" contamination, PAHs are not available for release to the pore water.

\subsection{Nereis-Hinia-Nucoloma test of sediments}

An established system for testing bioavailability of contaminants in marine sediments (Hylland et al. 1996; Ruus et al. 2005) was used. Species studied in this experimental setup was the polychaete Nereis diversicolor and the gastropod Hinia reticulata. Polychaetes and molluscs represent two important groups in marine ecosystems. $N$. diversicolor is common along the coasts of Europe, from the Mediterranean to Helgeland (mid Norway), and in the Baltic Sea. It is found primarily in shallow waters, where it can be found in dense populations. Hinia reticulata is also found in shallow waters and is common from the Canary Islands and the Azores in the south, to Lofoten in the north. Both species prefer sandy or muddy sediment and tolerate low salinities. $N$. diversicolor is omnivorous, while $H$. reticulata is a scavenger and a predator, but can also utilise organic matter in the sediment. $N$. diversicolor is one of the most studied marine invertebrates and has also been used in other bioaccumulation studies. For different reasons an attempt was made to include a third organism. The protobranch bivalve Nuculoma tenuis was chosen, based on the following criteria:

1. A sufficient number of organisms can be obtained

2. The organism should be a relevant bottom dwelling species, being a sub-surface selective deposit feeder.

Sediments were collected in the vicinity of four Norwegian and one Swedish aluminium smelter. Unpolluted sediments for use as a control/reference were collected from a clean site (in the outer Oslo Fjord) and underwent the same treatments as all other sediments. Finally, a spiked sediment sample (control sediment, spiked with selected PAHs) was prepared, and tested correspondingly.

Nereis and Hinia exposure experiments were performed in all-welded glass aquaria $(15 \mathrm{~cm} \times 20 \mathrm{~cm} \times 22 \mathrm{~cm})$; holding $5 \mathrm{l}$ of water/sediment), placed on a water-bath-table with header-tanks (secondary; with the same number of outlets as the number of aquaria). Each aquarium had an outlet $5 \mathrm{~cm}$ below the top, covered with a plastic netting to prevent organisms from escaping. To maintain a proper flow through, two plexi glass partition walls were attached in each aquarium. By the use of a main headertank, a constant, uniform water supply (150-200 $\mathrm{ml} / \mathrm{min}$ ) was maintained in all aquaria. The water supplied to the aquaria was pumped from $60 \mathrm{~m}$ depth outside NIVA's marine research station Solbergstrand. The same 
water was supplied to the water-bath to uphold a stable temperature in the aquaria. Temperature and salinity were logged with WTW electrodes every minute in the primary header tank and measured to $7-8^{\circ} \mathrm{C}$ and 33.3-34.5\%o, respectively. Three replicate aquaria were used for each test sediment. The duration of the accumulation period was set to 28 days, since such exposure period will result in tissue residues within $80 \%$ of the steady-state tissue residues in most cases.

Polycyclic aromatic hydrocarbons (PAHs) have been and are a prioritised group of environmental contaminants in Norway and abroad. In Norway, point sources have primarily been discharges from aluminiumand ferromanganese-smelters using Søderberg anodes. These discharges have been substantial and high concentrations of PAHs have been found in sediments and mussels in the vicinity of the smelters. Currently, focus is on PAHs, especially with regard to planning remedial measures for contaminated sediments, in agreement with objectives of the implementation of the EU Water Framework Directive.

Although high concentrations of PAHs have been found in sediments in the vicinity of the smelters, the observed effects have been minor (Naes \& Oug 1998). It was hypothesized that the reason for this was that the PAH from smelters using the Søderberg-anode was adsorbed to particles to a much higher degree than what was reported. It is widely accepted that it is the dissolved fraction of pollutants that is available for interaction with biological tissues and thereby can cause bioaccumulation and/or biological effects. To further pursue this, the Norwegian Institute for Water Research investigated the bioavailability of PAHs from sediments outside several Nordic smelters using passive samplers for PAHs and actual bioaccumulation in an experimental setup. The aims of the project were as follows:

1. Verify the partitioning constants for the passive samplers used in the measurements (POM-SPE).

2. Measurements of site-specific partitioning coefficients for PAHs between sediment particles and water.

3. Quantification of the accumulation of PAH in bottom dwelling organisms. The rationale for this is to show if high partitioning coefficients correspond with reduced bioavailability.

\subsection{PSTS intercalibration results}

The results from the PSTS intercalibration are taken from Smedes et al. (2007a-c). In the validation of the passive sampler trial, an analysis of variance for the PSTS indicated that the main source of variance was chemical analysis of the sheets and the estimation of the sampling rate. The PAH analysis had higher variance between participating laboratories 
and the reference laboratory than PCB. In general, the sampling rate estimates between participating and reference laboratory were very similar, but uncertainty in the estimated sampling rate was high. The analytical variances and $R_{s}$ estimation are interrelated as the measured concentrations are used in calculating $\mathrm{R}_{s}$, so lowering the analytical variability between laboratories would be the main priority.

Contributions of handling, transportation, storage and analysis of blank sheets were not important for the overall variance.

The variance in the spiking with PRC in different series was on average $8 \%$ (excluding naphthalene- $\mathrm{D}_{8}$ and corone- $\mathrm{D}_{12}$, which was up to $20 \%$ ). Other studies indicate that $5 \%$ error may be contributed to the spiking of PRC.

Analysis of duplicate deployments of passive samplers in Dutch waters ranged from 3-14\% (mean 8\%) for both PAHs and CBs, an estimate that includes both analytical and sampling errors from different series.

A final source of error and uncertainty is the determination of partition coefficients, which are estimated to be 0.05 to 0.2 log units, resulting in a factor of 1.5 error. For the PSTS, everybody was expected to use the same partition coefficients, so the variance should not have been affected by this factor, but had to be taking into account as potential bias when calculating water concentrations for comparing with target or quality standards.

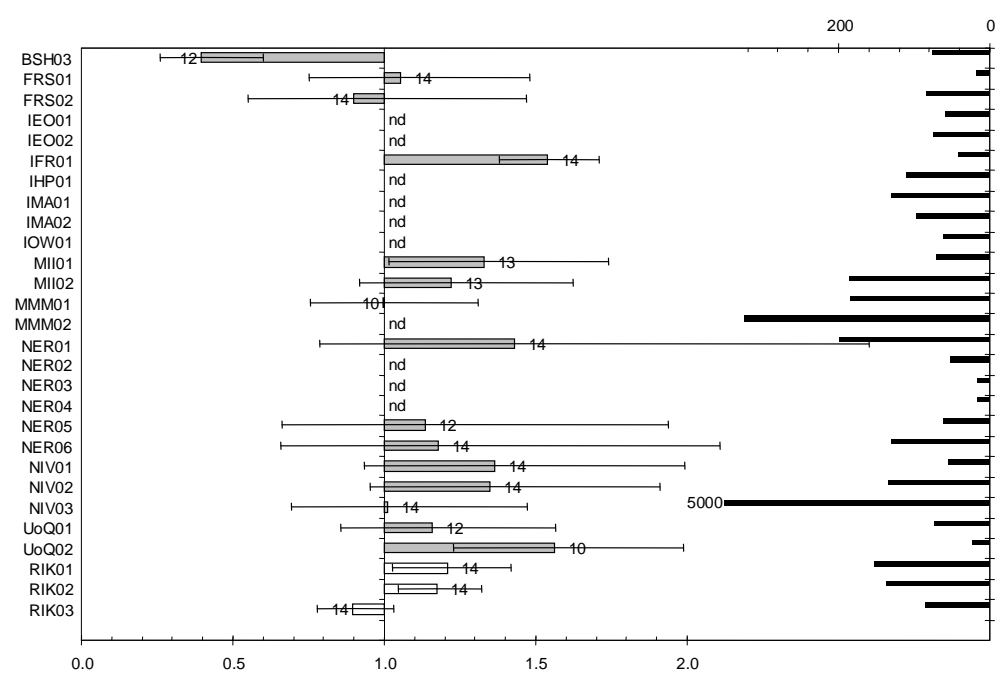

Figure 4.12 Intercalibration results for PAHs in passive samplers. The black bars to the right indicate the measured concentrations, with the scale on top. The ratio of participating laboratory to reference laboratory is indicated below, ranging for 0.3 to 1.5. In general NER and NIV PAHs were higher in participating laboratory by a factor 1.15 to 1.4 (except NIV03 close to 1), but taking into account the uncertainty of the measures, it was not significantly different from the reference lab. 


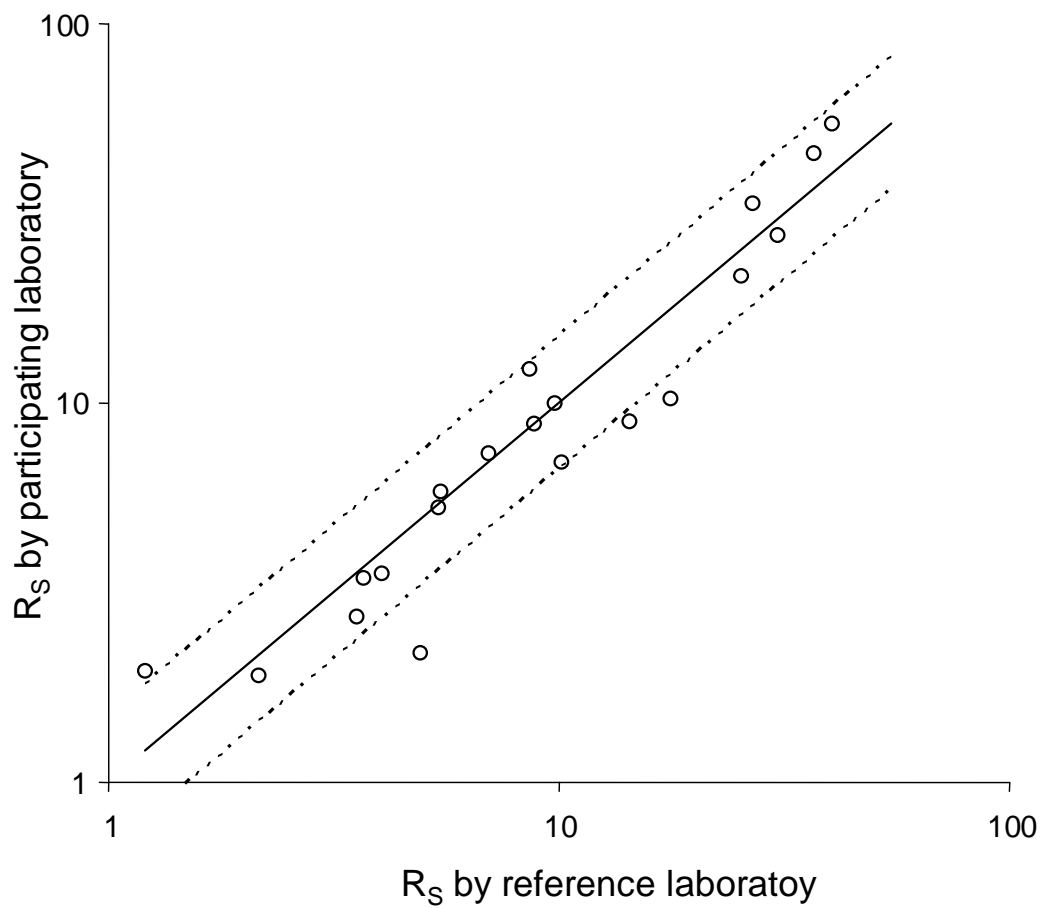

Figure 4.13 Comparison of sampling rates measured between RIKZ (reference laboratory) and the individual labs. The results suggest that a factor of two can arise from differences in analysis.

\section{Porewater from NER01}

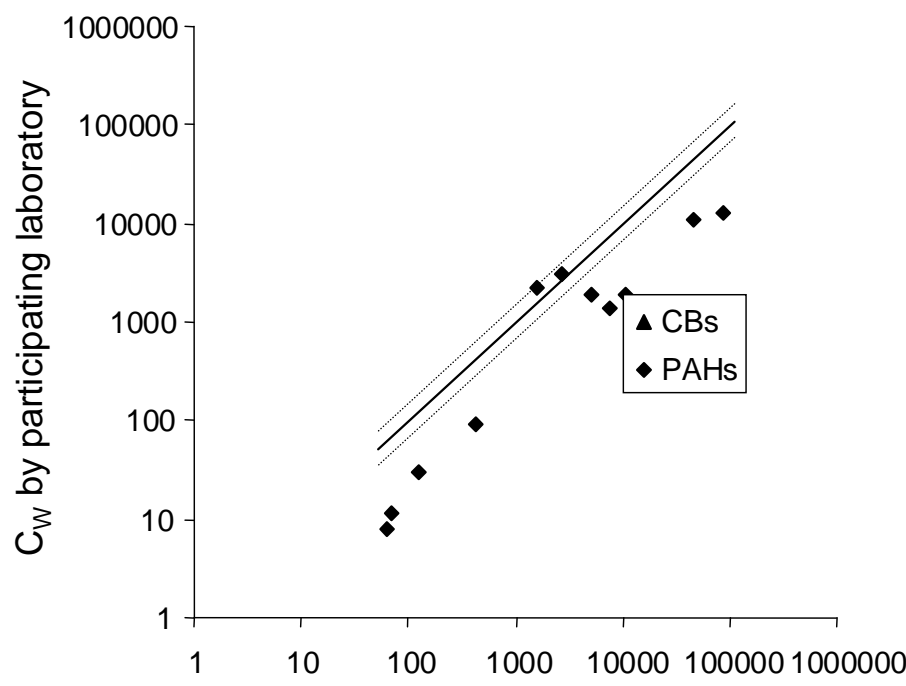

$\mathrm{C}_{\mathrm{W}}$ by reference laboratory

Figure 4.14 Pore water concentration of PAHs measured for NER01 by the participating vs. reference laboratory. The difference is up to a factor of 10. Some of the difference can be attributed to difference in $R_{s}$ calculation, as a more advanced method was used by the reference laboratory RIKZ. 


\subsection{Selected PSTS reference laboratory results}

The results of the PSTS survey, analysed and calculated by RIKZ, were presented at the ICES Annual Science Conference (ASC) in 2007, and figures from the presentation have been used by permission of Foppe Smedes, the coordinator of PSTS and presenter at the ICES ASC.

The passive samplers were deployed at 25 stations in the OSPAR area, and two stations in Queensland, Australia (shown in the figures in the Mediterranean Sea). As all samples were analysed at RIKZ, no interlaboratory variance is expected in figures 4.12 and forward. The $\mathrm{R}_{\mathrm{s}}$ was calculated based on all PRCs, both PAHs and PCBs, so it was determined with more certainty than what we could do in the Nordic participation having only PAH and PRCs available.

Examples of results for fluoranthene (figure 4.18), benzo[a]pyrene (B(a)P (figure 4.19) and CB153 (figure 4.20) for the whole of the OSPAR area are given. The most obvious observation is that the Norwegian NIV01 station at Karmoy is clearly the most polluted place with regard to dissolved PAHs in the water column, attributed to an aluminium smelter, but a difference in fluoranthene and $\mathrm{B}(\mathrm{a}) \mathrm{P}$ in the sediment pore water at that station indicates that $\mathrm{B}(\mathrm{a}) \mathrm{P}$ is not available in the pore water, despite high concentrations in the overlying water column. Figure 4.15 illustrates the difference between sediment pore water and overlying water at NIV01, indicating clearly that while $\mathrm{pg} / \mathrm{l}$ in water to sediment pore water of PCBs are close to 1:1 (broken line), the PAHs are a factor of 10-100 higher in pore water compared to water, indicating that sediments are a source of PAHs at this site (middle of Mosjon Fjord at $350 \mathrm{~m}$ depth). This was in accordance with the results of our own data (figure 4.6). This was not in general the case for other samples at Tagues estuary, Aberdeen Harbour and Zeebrugge (not shown). In general, the correlation of concentration in pore water and overlying water was collected around 1:1 for both PAHs and PCBs at the three other stations.

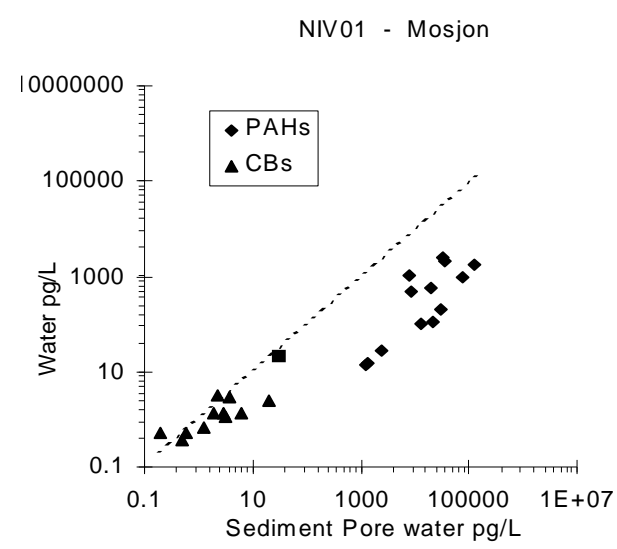

Figure 4.15 Relationship of sediment pore water to freely dissolved water concentrations for PAHs and CBs around NIV01. 
The apparent partition coefficient of sediment (note that the partitioning coefficient at the Y-axis $K_{o c}=K_{s w}$ ) to $K_{o w}$ of the compounds investigated are shown in figure 4.16. Also here, a linear relationship is observed, except that PAH of the native substances is above the 1:1 line.
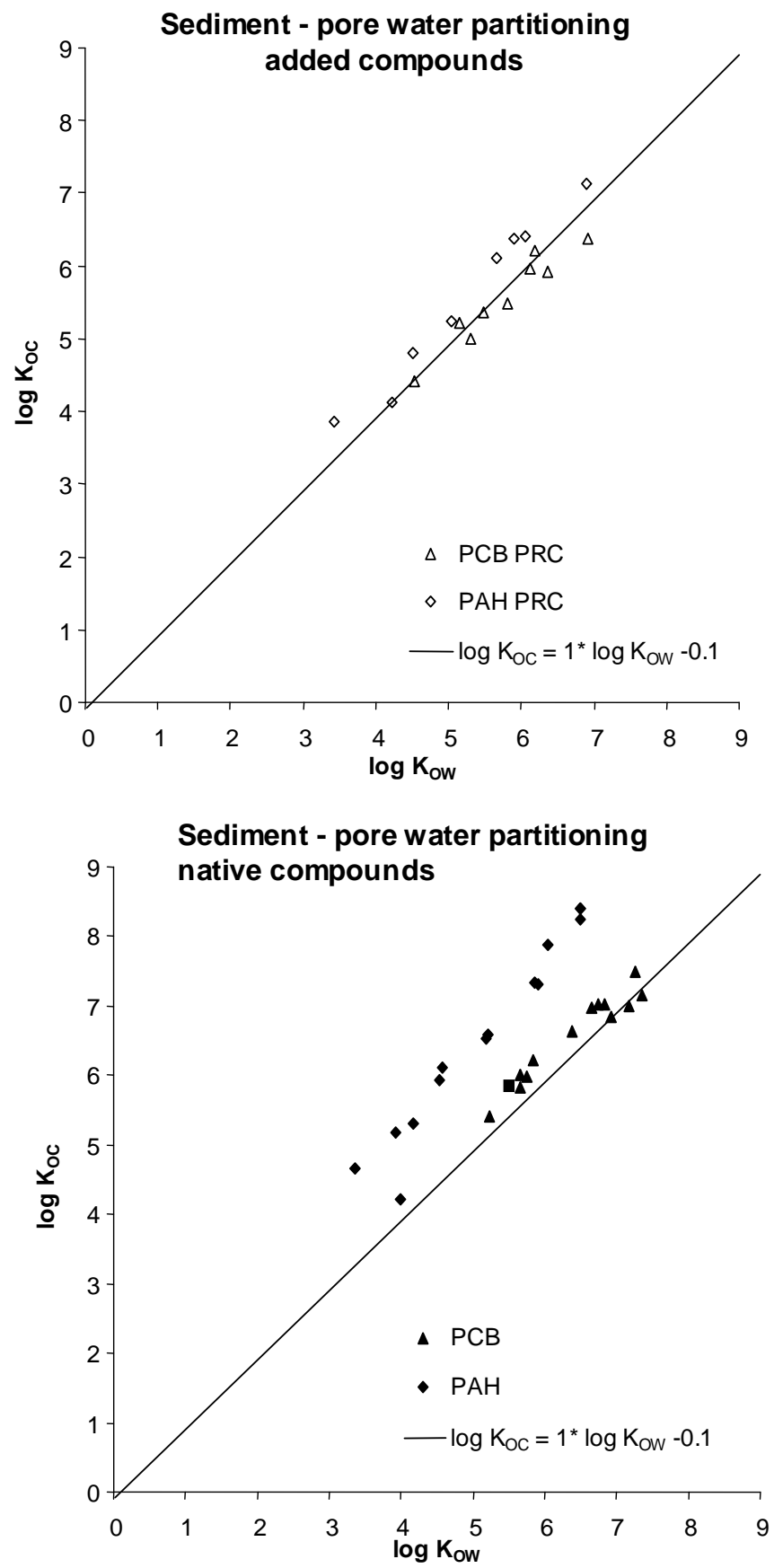

Figure 4.16 Relationship of pore water partitioning coefficients for PAHs and PCBs compared with $K_{o w}$ of the substances, the upper figure for performance reference compounds, lower for native components. Notice that for PAHs, native components are above the 1:1 line indicated, whereas PCBs are gathering around the 1:1 line for both native and performance reference compounds. 
For $\log K_{o w}$ to mussel bioconcentration factors (BCF, calculated as the ratio of ng/l in the water phase measured by passive samplers at RIKZ to mussel concentrations measured by the participating laboratories), a good linear relation was found (figure 4.17) that corresponded with a previously established model by Bergen et al. (1993). This indicates that log $K_{o w}$ (and hence the water concentrations calculated from the passive samplers) has a linear relationship, and that passive samplers are comparable with mussel, as it has been shown previously by Booij et al. (2006) and Smedes (2007).

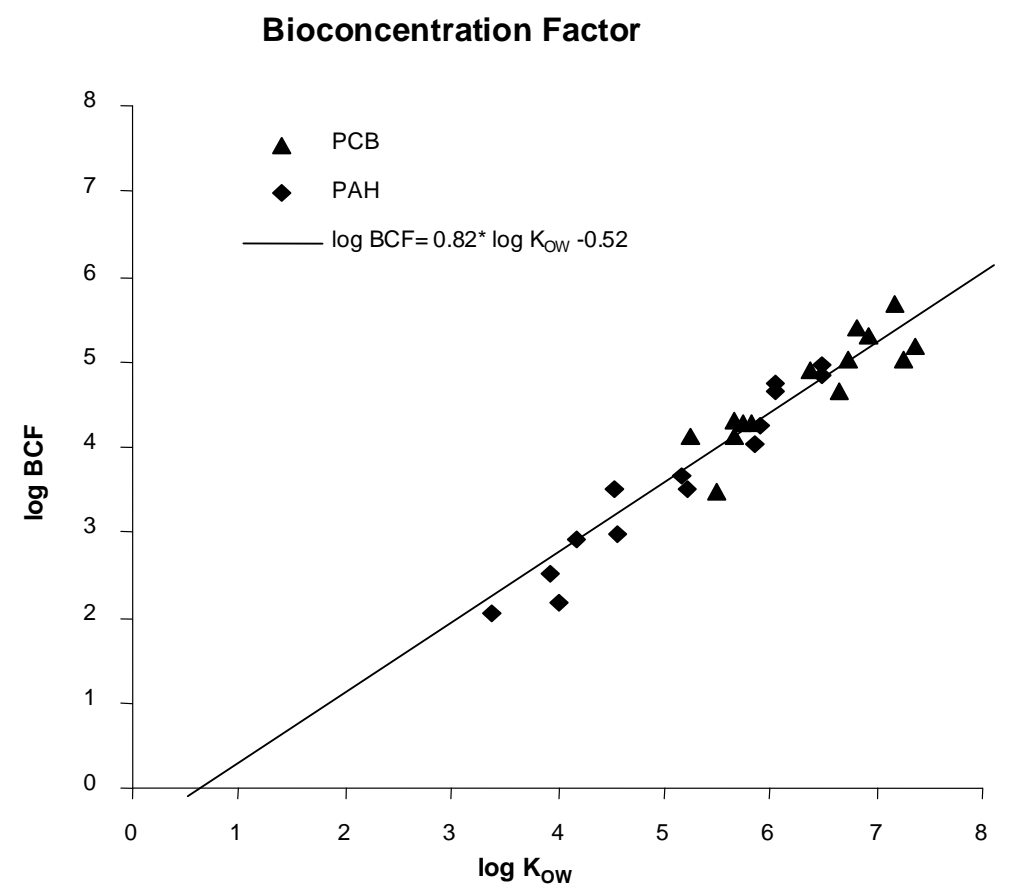

Figure 4.17 Relationship of bioconcentration factors of PAHs and PCBs compared with $K_{\text {ow }}$ of the substances. 
Flu (fluoranthene) freely dissolved in water in $\mathrm{pg} / \mathrm{L}$
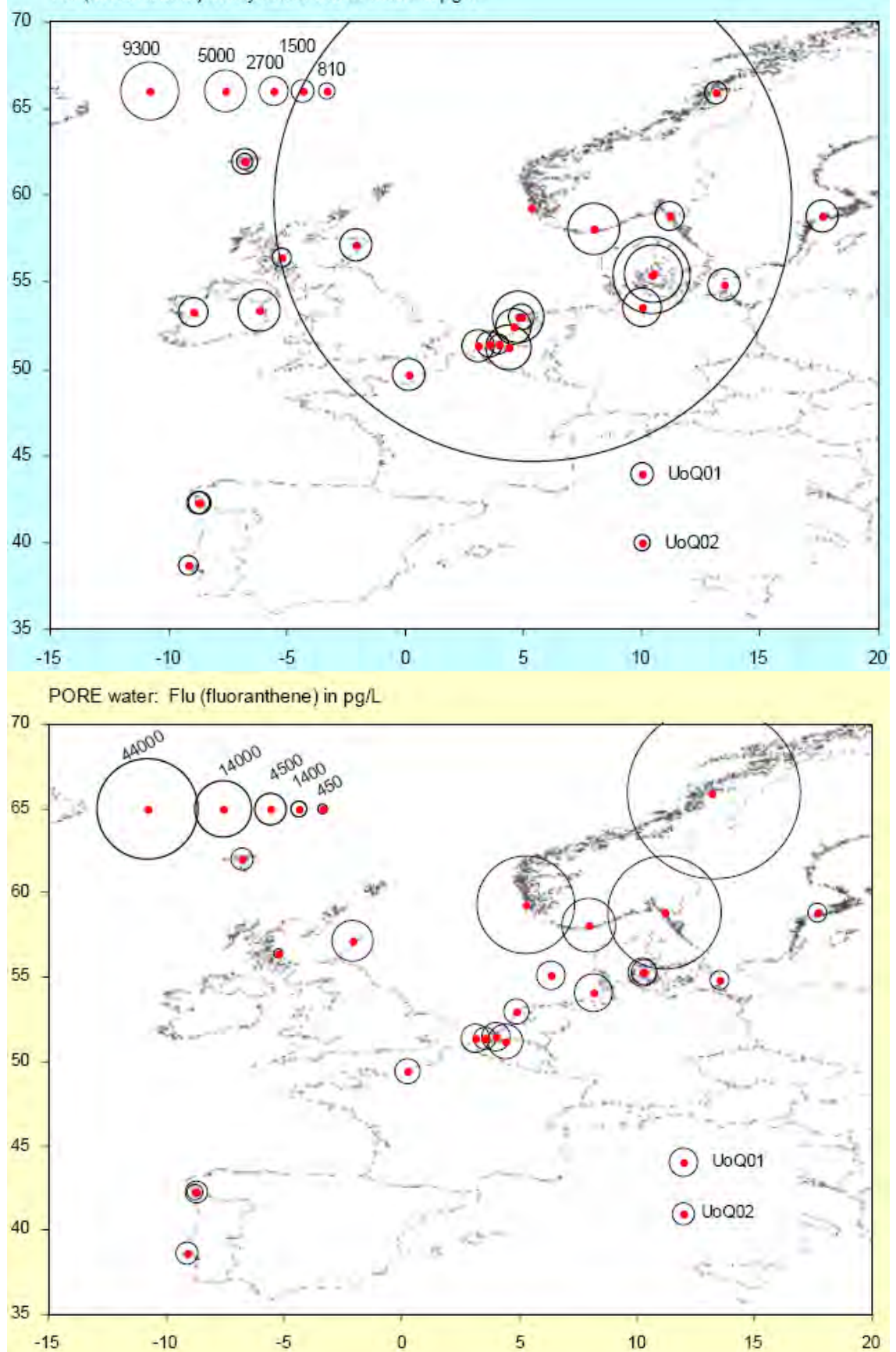

Figure 4.18 Fluoranthene in pg/l for water and pore water of sediments, as calculated and analysed at RIKZ. Notice the high level around the smelter in NIV01. Scale is given above the Faroe Islands, based on the area of the circles. Notice different scales in pore water and water. 
$\mathrm{BaP}$ (benzo[a]pyrene) freely dissolved in water in $\mathrm{pg} / \mathrm{L}$

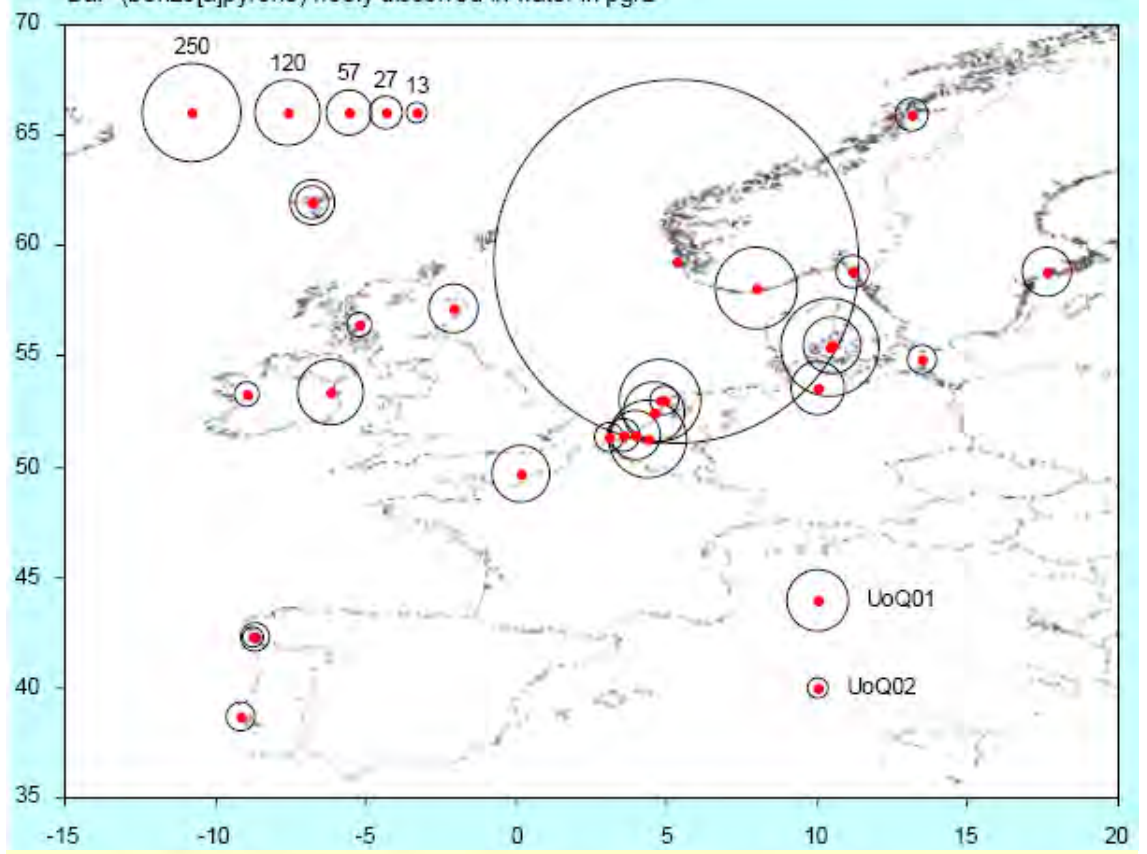

PORE water: BaP (benzo[a]pyrene) in pg/L

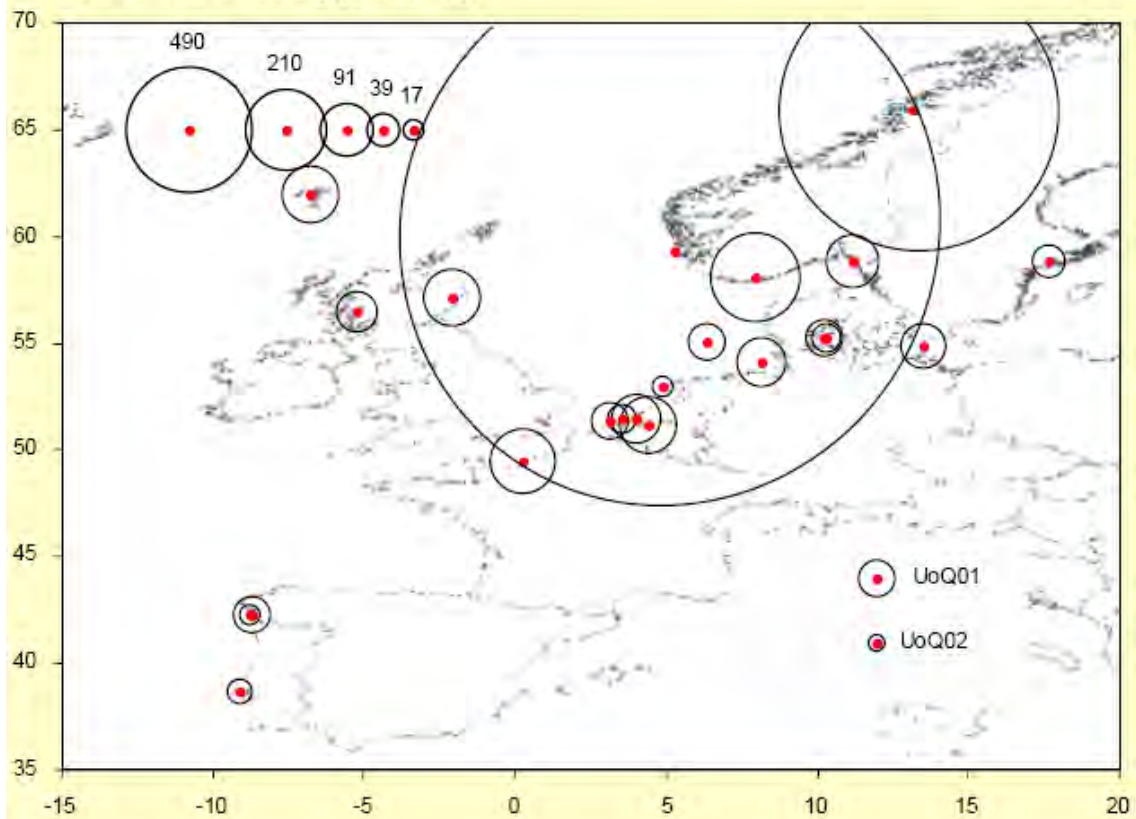

Figure 4.19 Benzo[a]pyrene in pg/l for water and pore water of sediments, as calculated and analysed at RIKZ. Notice the high level around the smelter in NIV01. Scale is given above the Faroe Islands, based on the area of the circles. Notice different scales in pore water and water. 
CB153 (2, $2^{\prime}, 4,4^{\prime}, 5,5^{\prime}$-hexachlorobiphenyl) freely dissolved in water in pg/L

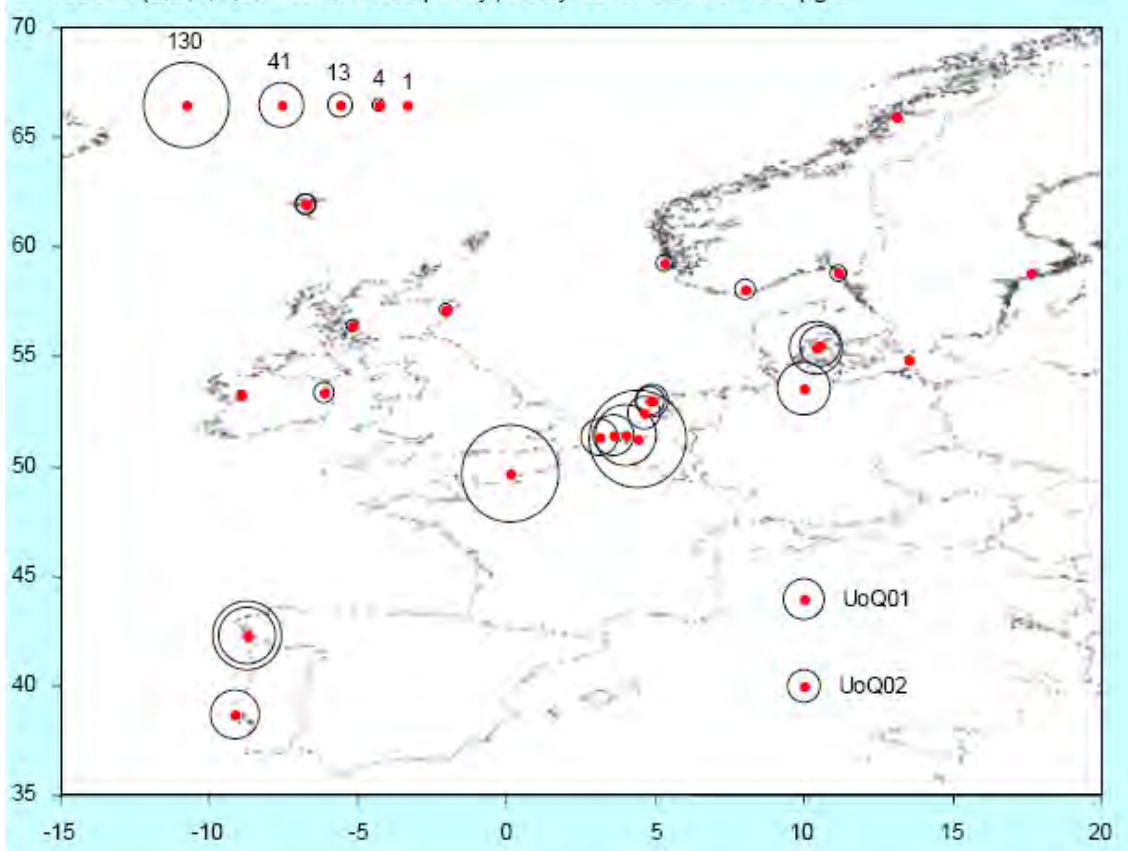

PORE water: CB153 $\left(2,2^{\prime}, 4,4^{\prime}, 5,5^{\prime}\right.$-hexachlorobiphenyl) in pg/L

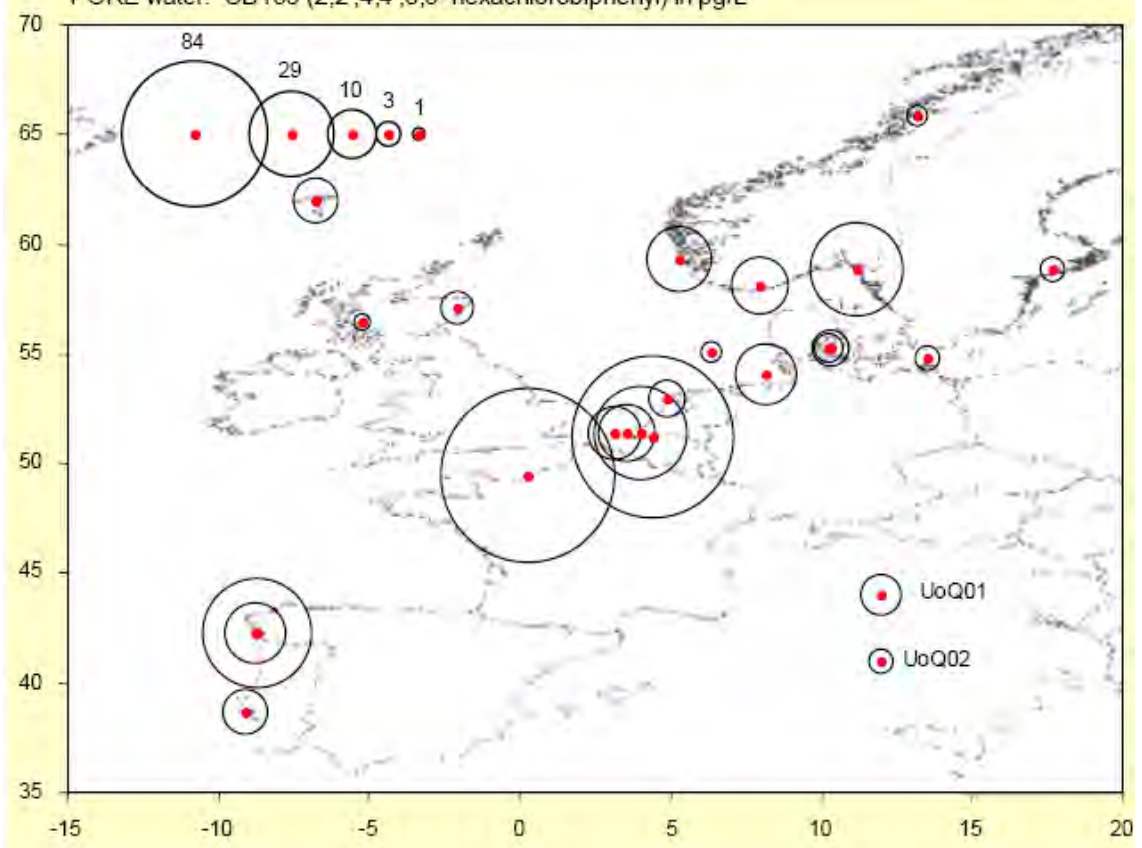

Figure 4.20 CB153 in pg/l for water and pore water of sediments, as calculated and analysed at RIKZ. The highest values are found around France, and the highest Nordic concentration in pore water in Sweden. Scale is given above the Faroe Islands, based on the area of the circles. Notice different scales in pore water and water. 
The extracts of the passive samplers were also analysed for substances, for which no $\log K_{o w}$ or $\log K_{o c}$ was available, but were of interest for OSPAR or the EU Water Framework Directive. This included endosulfan-1, trifluralin, chlorpyrifos and brominated flame-retardants. For most substances, detection limits were_in the range of $0,2-10 \mathrm{pg} / \mathrm{l}$, better than obtainable by direct analysis of seawater, and all were found above detection limits at most stations.

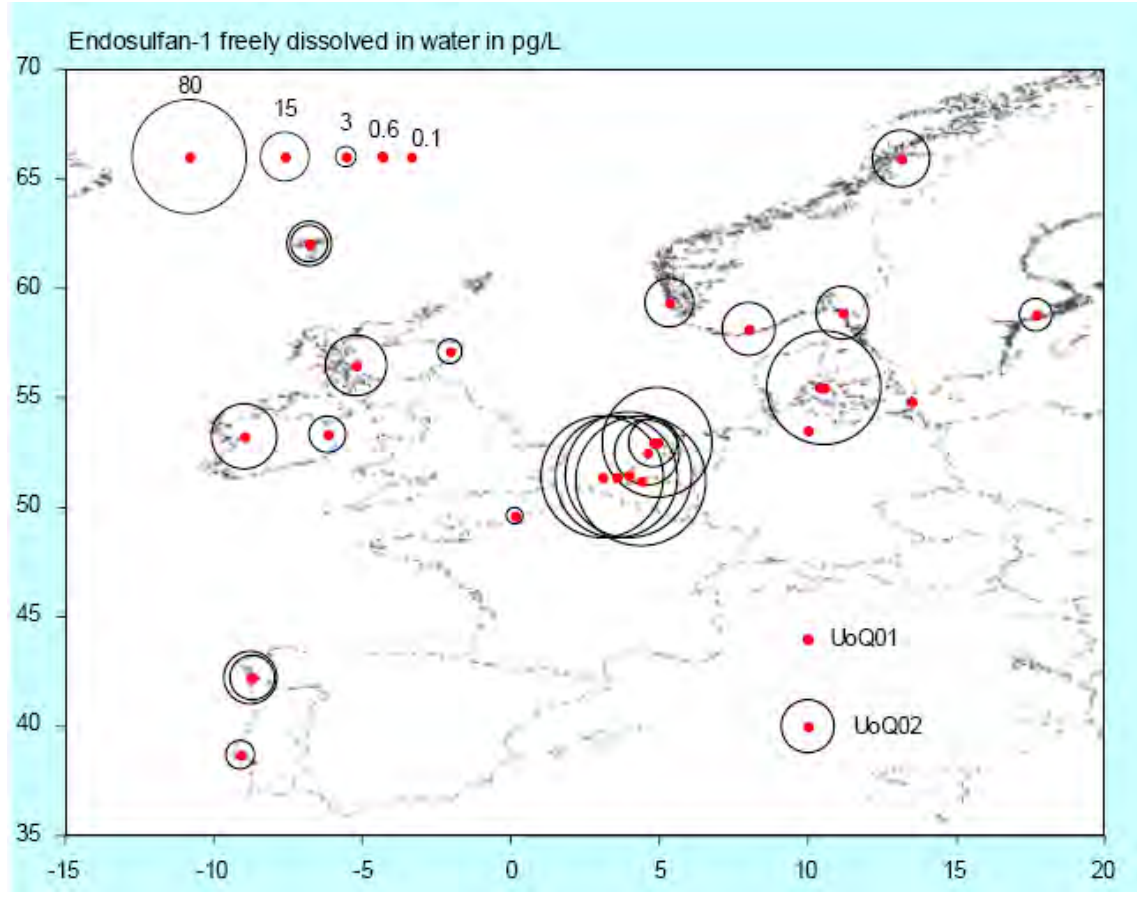

Figure 4.21 Estimated endosulfan-1 concentrations from the passive samplers. An example of an EU Water Framework Directive substance that also could be measured in passive samplers. 


\section{Discussion}

\subsection{Status of PSTS within OSPAR/ICES}

The method of choice for PSTS was silicone rubber. Guidelines for the analysis and deployment are currently being prepared at ICES MCWG and WGMS. OSPAR MON and SIME have been looking at the results, and consider implementing the use of passive samplers in the Coordinated Environmental Monitoring Programme (CEMP), when the final results of the PSTS are available, and the work with QSR 2010 are finished in 2009. For the use of passive samplers to become mandatory under the CEMP, guidelines, assessment criteria and quality assurance need to be in place, and QUASIMEME are currently offering an intercalibration service for passive samplers, so in principle when assessment criteria (e.g. EQS for the calculated water concentrations) and the guidelines are in place, using passive samplers could become mandatory under the CEMP.

\subsection{Experience with PSTS in the Nordic countries}

The problem with analysis of PCBs in the passive samplers will have to be solved before using the methods in ordinary monitoring. This problem could be solved by using another internal standard (IS) in the PCB method, so that no interference between silicone sheet extracts and IS occurs. The detection limits for $\mathrm{PAH}$ in the low $\mathrm{K}_{\mathrm{ow}}$ range should also be optimised, but in most cases it is adequate with deployment time of 3-4 weeks.

Deployment and recovery were very easy with the system used, and none of the samplers were lost. In Greenland, the buoys for keeping up the system were two 50 litre plastic bottles, which worked fine even when one was punctured by rifle shots.

Two sampling frames were obtained for use after the PSTS finished, and four sets of samplers for deployment on the bottom, sampling approx. $1 \mathrm{~m}$ above the sediment, were prepared at NERI for use in Greenland. A workshop on calculating the water concentrations was held at Søminestationen close to Holbæk Fjord, Denmark, in November 2008 (see Annex 4), and discussions on the further use of passive samplers in the Nordic countries was overall positive. 


\subsection{Experience with passive samplers in the Nordic countries}

\subsubsection{Norwegian experience with passive samplers}

Considerable use and experience in the use of passive samplers have been gained in Norway in recent years. Passive sampling has been used routinely for tracing contaminant sources in rivers and for mapping and assessing the distribution of contamination in coastal waters where for example PAH releases from aluminium smelters have been traced. Passive sampling devices such as SPMDs have been used in such exercises; however, samplers for metals such as DGT have also been in routine use at NIVA. Recent developments include simplification of the preparation and extraction steps by using more simple polymeric membranes such as silicone and LDPE (SPMD without the triolein).

Equilibrium passive samplers are promising tools to determine freely dissolved aqueous concentrations $\left(\mathrm{CW}_{\text {free }}\right)$ of hydrophobic organic compounds. Their use in the field, however, remains a challenge. In the present study on native polycyclic aromatic hydrocarbons (PAHs) in Oslo Harbour, Norway, two different passive sampler materials, polyoxymethylene (POM; thickness, $55 \mu \mathrm{m}$ [POM-55] and $500 \mu \mathrm{m}$ [POM-500]) and polydimethylsiloxane (PDMS; thickness, $200 \mu \mathrm{m}$ ), were used in the laboratory to determine $\mathrm{CW}_{\text {free }}$ in sediment pore water $\left(\mathrm{CW}_{\text {free }}\right)$, and the suitability of five passive samplers for determination of $\mathrm{CW}_{\text {free }}$ in overlying surface water was tested under field conditions. For laboratory determinations of $\mathrm{CW}_{\text {free, }}$ both POM-55 and PDMS turned out to be suitable. In the field, the shortest equilibrium times (approximately one month) were observed for POM-55 and PDMS (thickness, $28 \mu \mathrm{m}$ ) coatings on solid-phase micro-extraction fibres, with PDMS tubing as a good alternative. Low-density polyethylene (thickness, $100 \mu \mathrm{m}$ ) and POM-500 did not reach equilibrium within 119 days in the field. Realistic values were obtained for dissolved organic carbon-water partition coefficients in the field (approximately one log unit under $\log K_{O W}$ ), which strengthened the conclusion that equilibrium was established in field-exposed passive samplers. At all four stations, chemical activity ratios between pore water and overlying water were greater than one for all PAHs, indicating that the sediment was a PAH diffusion source and that sediment remediation may be an appropriate treatment for PAH contamination in Oslo Harbour.

\subsubsection{Danish and Swedish experience with passive samplers}

POSIC samplers have been used in both Denmark and Sweden, with successful documentation of many new substances in the marine environment. The main problem has been the calibration of POSIC samplers in marine waters, as they have mainly been verified in fresh water so far. 


\subsection{Use of passive samplers in national monitoring}

The main obstacle for the use of passive samplers in monitoring is whether the calculated free dissolved concentrations can be used to assess the status, especially the relation to EU's environmental quality standards, which are based on total water concentrations. The health of e.g. mussels is a combined effect of direct uptake from water and food, or other particles in the water phase, so EQSs may need to be adjusted for passive sampler measurements, or the contamination in fine particles needs to be added to the free dissolved concentrations for water of "standard composition".

Passive samplers applied to the sediments offer an opportunity to measure the fraction of contaminants that are available in the pore water, disregarding contaminants bound hard in the sediment that only poses a threat to sediment eating organisms. The passive sampler concentration in the pore water can be directly compared with passive sampler concentrations measured in the overlying water to assess whether the sediment acts as a source or sink to contaminants, and thus could be used to assess if sediment poses a threat to the water.

If the aim is to replace mussels with passive samplers, calibration factors between mussels and passive samplers should be established for each site and laboratory before changing from mussel to passive samplers (see section 4.5 above).

Several countries participating in the PSTS are currently pursuing passive samplers as a tool. Only the Netherlands have an established programme, but the UK is starting out with 50 stations of silicone rubber and POCIS samplers in 2009, and Belgium and Ireland both have started or are close to start deploying passive samplers with the aim to correlate with biological effects. Mainly passive sampling of the water phase is planned; more work is needed before passive sampling of pore water in sediments will be implemented in national monitoring programmes. 



\section{Conclusions}

The passive sampler trial survey, using silicone sheet passive samplers, demonstrated the usefulness of passive samplers in a North Sea wide context. The passive samplers were shown to be applicable in the whole of the OSPAR convention area, and for a wide range of persistent organic contaminants in the WFD and OSPAR lists of compounds for priority action. The comparability of calculated free water concentrations between laboratories in the participating countries and the reference laboratory leaves room for improvements; some of the discrepancies were most likely due to different calculation methods for $\mathrm{R}_{\mathrm{s}}$, but the comparability is more or less on the same level as mussel and sediment surveys already, and far better than what could be expected for measuring directly in the water phase. A currently ongoing QUASIMEME intercalibration exercise on the passive sampler materials will hopefully improve this situation. More experience and guidelines could make passive samplers a more homogeneous tool for EU-wide investigations. For the OSPAR system, intercalibration, guidelines and assessment criteria are the driving force for methods to become mandatory, and the former two are probably ready by 2010 or 2011, so when assessment criteria are established, the passive samplers could become a mandatory part of OSPAR's Coordinated Environmental Monitoring Programme (CEMP).

\subsection{National Nordic monitoring}

Passive samplers are currently not used in national monitoring programmes in the Nordic countries, but in Norway they have been extensively used for investigative monitoring purposes.

In Denmark, passive samplers have been used for screening, and currently a project for using passive samplers in screening for endocrine disrupters is running. Development of passive samplers for the use in future national monitoring has been suggested, but not decided upon yet, as the possible link to the Water Framework Directive has not been determined. Swedish programmes have also been mainly concerned with screening of WFD substances in coastal waters.

\subsection{OSPAR monitoring}

In the OSPAR area, Holland and Belgium are currently using silicone sheets for monitoring. The UK are preparing to set up 50 stations using 
POSIC and silicone sheets and Ireland are planning to deploy samplers at the edge of the North Sea shelf to obtain background measurements of the freely dissolved PAH and PCBs in deep ocean water (down to $300 \mathrm{~m}$ ).

The PSTS programme has spurred great interest in the use of passive samplers, and in many cases, the easy access to distribution coefficient and the use of PRCs in silicone sheets are pushing the use of especially silicone sheets into the forefront of passive sampling work in the OSPAR area.

Development of guidelines and quality assurance programmes for passive samplers - using silicone sheets - is underway, and will probably be ready in 2010, together with the case study in the QSR 2010. Furthermore, when developments in the different national programmes have been taken into account, the inclusion of passive samplers in the Coordinated Environmental Monitoring Programme in OSPAR could become a reality in the near future.

\subsection{EU WFD/Marine Strategy}

The work in ICES/OSPAR on passive samplers can influence the implementation of the Marine Strategy Framework Directive in Europe. In the WFD, passive samplers are mentioned as one way of obtaining time integrated monitoring data, and the PSTS has shown that many of the substances in the WFD can be measured in silicone sheets. The two main outstanding problems before using passive samplers in WFD monitoring are: To agree on which assessment criteria to use with passive samplers, as passive samplers measure the freely dissolved fraction rather than the total water concentration of substances. Secondly, to determine the distribution coefficient between the water and silicone sheets for all substances that will be measured by passive samplers. 


\title{
Acknowledgements
}

\author{
Nordic Council of Ministers
}

1. For sponsoring the analysis and exchange of ideas between the Nordic countries

NERI, AU (National Environmental Research Institute, Aarhus University, Denmark)

2. Morten Hjort, Ingela Dahllöf and Gitte Jacobsen for assistance with deploying the samplers in Greenland and handling in Denmark

3. Ingela Dahllöf and Colin Stedmon for helpful comments on the report, and Anne van Acker for layout and carefully reading the report

4. County of Odense for help in deploying samplers in Odense Fjord

NIVA (Norwegian Institute for Water Research)

5. Olav Boyum for analysis and assistance in reporting of results

6. Internal research money for participation and extension of PSTS programme

US (Environmental Agency Research)

7. Maria Dam for getting the project started and assisting Katrin

8. Bjørki Geyti for assistance in deploying and retrieving the passive samplers

NRM (The Swedish Museum of Natural History, Sweden)

9. Anders Bignert for getting the project started and assisting Elisabeth

Foppe Smedes, former RIKZ, now DELTARES

10. for organising the PSTS and for reading and helpfully commenting on the report. 



\section{References}

Allan, I.J., Vrana, B., Greenwood, R., Mills, G.A., Roig, B. \& Gonzalez, C. (2006): A "toolbox"for biological and chemical monitoring requirements for the European Union's Water Framework Directive. - Talanta 69: 302-322.

Allan, I.J., Knutsson, J., Guigues, N., Mills, G.A., Fouillac, A-M. \& Greenwood, R. (2007): Evaluation of the Chemcatcher and DGT passive samplers for monitoring metals with fluctuating water concentrations. - Journal of Environmental Monitoring 9: 672-681.

Alvarez, D.A., Huckins, J.N., Petty, J.D. \& Manahan, S.E. (1999): Progress towards the development of a passive, in situ, SPMD-like sampler for hydrophilic organic contaminants in aquatic environments. - Poster presentation at the 20th Annual US SETAC meeting, Philadelphia, November 14-18, 1999.

Bergen, B.J., Nelson, W.G. \& Pruell, R.J. (1993): Bioaccumulation of PCB congeners by blue mussels (Mytilus edulis) deployed in New Bedford Harbor, Massachusetts. - Environ. Sci. Technol. 12: 1671-1681.

Booij, K., van Weerlee, E.M., Fischer, C.V. \& Hoedemaker, J. (2000): Passive sampling of organic contaminants in the water phase. - Report from the Netherlands Institute for Sea Research: NIOZ Report 2000-5, ISBN 0923-2310.

Booij, K., Smedes, F. \& van Weerlee, E.M. (2002): Spiking of performance reference compounds in low density polyethylene and silicone passive water samplers. - Chemosphere 46: 1157-1161.

Bossi, R., Dahllöf, I., Larsen, M.M. \& Lassen, P.(2009): Passive opsamplere for miljøfremmede stoffer i vandmiljøet. - Dansk Kemi 90 (8) 22-25.
Broman, D., Cornelissen, G. , Wiberg, K. \& Tysklind M. (2008): Polyklorerade dibenso-p-dioxiner och dibensofuraner (PCDD/F) i vatten utanför massa-, pappers- och träindustrier. - Rapport från mätningar med sedimentfällor och passiva provtagare.

Cornelissen, G., Broman, D., Wiberg, K. \& Tysklind, M. (2006): Dioxiner på Mariebergs PCP-impregneringsområde Fas 1: förbättrad riskbedömning för upptag i organismer och transport till grundvatten. - Projektrapport ITM \& Umeå Universitet, via SGU och NVV 1 December 2006.

Cornelissen, G., Pettersen, A., Broman, D., Mayer, P. \& Breedveld, G.D. (2008): Field Testing of Equilibrium Passive Samplers to Determine Freely Dissolved Native Polycyclic Aromatic Hydrocarbon Concentrations. - Environmental Toxicology and Chemistry 27(3): 499508.

Dahllöf, I., Mogensen, B.B., Bossi, R. \& Jensen, I. (2008): Forekomst af herbicider i Nissum Fjord. Danmarks Miljøundersøgelser, Aarhus Universitet. 21 s. Arbejdsrapport fra DMU nr. 244 (in Danish). http://www.dmu.dk/Pub/AR244.pdf

Górecki,, T.\& Namiesnik, J. (2002): Passive sampling. - Trends in Analytical Chemistry 21(4): 276-292.

Huckins, J.N., Tubergen, M.W. \& Manuweera, G.K. (1990): Semipermeable membrane devices containing model lipid: a new approach to monitoring the bioavailability of lipophilic contaminants and estimating their bioconcentration potential. - Chemosphere 20: 533-552.

Hylland, K., Sköld, M., Gunnarsson, J.S. \& J. Skei (1996): Interactions between eutrophication and contaminants. IV. Effects on sediment-dwelling organisms. - Marine Pollution Bulletin 33 (1-6) 90-99. 
Jahnke, A., McLachlan, M.S. \& Mayer, P. (2008): Equlibrium sampling: Partitioning of organochlorine compounds from lipids into polydimethylsiloxane. Chemosphere - Global Change Science 73(10): 1575-1581.

Kingston, J., Greenwood, R., Mills, G., Morrison, G.M. \& Persson, L.B. (2000): Development of a novel passive sampling system for the time-averaged measurement of a range of organic pollutants in aquatic environments. J. Environ. Monit 2, 487-495.

Kot-Wasik,A., Zabiegała, B., Urbanowicz, M., Dominiak, E., Wasik, A. \& Namiesnik. J. (2007): Advances in passive sampling in environmental studies. - Analytica Chimica Acta 602: 141-163.

Liu, J, Toräng, L, Mayer, P \& Jönsson, J.Å. (2007): Passive extraction and clean-up of phenoxy acid herbicides in samples from a groundwater plume using hollow fiber supported liquid membranes. Journal of Chromatography A, 1160: 56-63.

Mayer, P., Reichenberg, F. \& Toräng, L. (2008): Device and Method for Isolation, Concentration and/or Identification of Compounds, BO1L 3/14 (2006.01) Sep. 25. Patent.

Naes, K. \& Oug, E. (1998): The distribution and environmental relationships of polycyclic aromatic hydrocarbons (PAHs) in sediments from Norwegian smelter-affected fjords. - Chemosphere 36(3) 561-576.

Namiesnik, J. B. Zabiegała, B., KotWasik, A., Partyka, M. \& Wasik, A. (2005): Passive sampling and/or extraction techniques in environmental analysis: a review. - Anal Bioanal Chem 381: 279-301.

Ossiander, L., Reichenberg, F., McLachlan, M.S. \& Mayer, P. (2008): Immersed solid phase microextraction to measure chemical activity of lipophilic organic contaminants in fatty tissue samples. Chemosphere 71: 1502-1510.

Peterson, S.M., Apte, S.C., Batley, G.E. \& Coade, C. (1995): Passive sampling for chlorinated pesticides in estuarine waters. - Chem. Spec. Bioavail 7: 83-88.
Reichenberg, F., Smedes, F., Jönsson, J.Å., J \& Mayer, P. (2008): Determining the chemical activity of hydrophobic organic compounds in soil using polymer coated vials. - Chemistry Central Journal 2: 8.

Rusina, T.P., Smedes, F., Klanova, J., Booij, K. \& Holoubek, I. (2007): Polymer selection for passive sampling: A comparison of critical properties. Chemosphere 68: 1344-1351.

Ruus, A., Schaanning, M., Oxnevad, S. \& Hylland K. (2005): Experimental results on bioaccumulation of metals and organic contaminants from marine sediments. - Aquatic Toxicology, 72(3): 273-292.

Seethapathy, S., Górecki, T. \& Xiaojing $\mathrm{Li}, \mathrm{X}$. (2008): Passive sampling in environmental analysis. - Journal of Chromatography A, 1184: 234-253.

Smedes, F., Tixier C,.Davies I.M., Roose, P., van der Zande, T. \& Tronczynski, J. (2006): Protocol for Participants: Passive Sampling ICES Trial survey for hydrophobic organic contaminants in water and sediment; including laboratory intercalibration. ICES/WGMS and MCWG. - from passivesampling.net

Smedes F. (2007): Monitoring of Chlorinated Biphenyls and Polycyclic Aromatic Hydrocarbons by Passive Sampling in Concert with Deployed Mussels. - In: Greenwood R., Mills, G. \& Vrana, B. (Eds.) - Comprehensive Analytical Chemistry 48, Elsevier.

Smedes, F., Davies I.M. \& Tronczynski J. (2007a): ICES Passive sampling trial survey for water and sediment (PSTS) 2006 - 2007. Part 1: Objectives, Design and Realization . - Presentation at the annual ICES Science Conference, Helsinki. ICES CM 2007/J:02.

Smedes, F., van der Zande, T., Tixier C. \& Davies I.M. (2007b): ICES Passive sampling trial survey for water and sediment (PSTS) 2006 - 2007. Part 2: Laboratory intercomparison, analytical issues and lessons learned. - Presentation at the annual ICES Science Conference, Helsinki. ICES CM 2007/J:03.

Smedes, F., van der Zande, T., Roose P. \& Davies I.M. (2007c): ICES Passive sampling trial survey for water and sediment (PSTS) 2006 - 2007. Part 3: Preliminary interpretation of field data. - Presentation at the annual ICES Science Conference, Helsinki. ICES CM 2007/J:04. 
Stuer-Lauridsen F. (2005): Review of passive accumulation devices for monitoring organic micropollutants in the aquatic environment. - Environmental Pollution 136(3): 503-524.

Stuer-Lauridsen, F., Mogensen, B., Fatum, P., Jacobsen, J.A., Poulsen, M.E., Larsen, H., Pedersen, F., Pedersen, G. \& Pritzl, G. (1996): Estimation of Dissolved Concentrations of Hydrophobic Pollutants in Water by Semipermeable Membrane Devices. - Paper presented at SETAC-Europe Annual Meeting, Taormina. 19-22 May 1996.

Stuer-Lauridsen, F. \& Birkved, M. (2000): Nye metoder til overvågning af miljøfremmede stoffer i vandmiljøet. COWI for Miljøstyrelsen, Miljøprojekt 542 (in Danish).

SWECO VIAK (2007): Nationwide screening of WFD priority substances. Screening Report 2007:1 for the Swedish Environmental Protection Agency.

Södergren, A. (1987): Solvent-filled dialysis membranes simulate uptake of pollutants by aquatic organisms. - Environ. Sci. Technol 21: 855-859.

Tuxen, N., Troldborg, M., Kofoed, J.L.L., Raun, K.D., Binning, P.J. \& Bjerg, P.L. (2007): Forureningsflux fra en TCEforurenet lokalitet: Sammenligning af metoder. - ATV-møde, vintermøde om jord- og grundvandsforureing, Vingstedcentret 6.-7. marts 2007.

Verbruggen, E.M.J., van Loon, W.M.G.M., Tonkes, M., van Duijn, P., Seinen, W. \& Hermens, J.L.M. (1999): Biomimetic extraction as a tool to identify chemicals with high bioconcentration potential: an illustration by two fragrances in sewage treatment plant effluents and surface waters. Environ. Sci. Technol 33, 801-806.
Verbruggen, E.M.J., Vaes, W.H.J., Parkerton, T.F. \& Hermens, J.L.M. (2000): Polyacrylate-coated SPME fibers as a tool to simulate body burdens and target concentrations of complex organic mixtures for estimation of baseline toxicity. - Environ. Sci. Technol 34: 324-331

Verhaar, H.J.M., Busser, F.J.M. \& Hermens, J.L.M. (1995): Surrogate parameter for the baseline toxicity content of contaminated water: simulating the bioconcentration of mixtures of pollutants and counting molecules. - Environ. Sci. Technol 29: 726-734.

Vrana, B., Mills, G.A., Allan, I.J., Dominiak, E., Svensson, K., Knutsson, J., Morrison, G. \& Greenwood, R. (2005): Passive sampling techniques for monitoring pollutants in water. - Trends in Analytical Chemistry 24(10).: 845868 doi:10.1016/j.trac.2005.06.006

Vrana, B., Mills, G.A., Dominiak, E. \& Greenwood, R. (2006): Calibration of the Chemcatcher passive sampler for the monitoring of priority organic pollutants in water. - Environmental Pollution 142(2): 333-343.

Vrana, B., Mills, G.A., Kotterman, M., Leonards, P., Booij, K. \& Greenwood, R.: (2007): Modelling and field application of the Chemcatcher passive sampler calibration data for the monitoring of hydrophobic organic pollutants in water. - Environmental Pollution 145: 895-904.

Zabiegała, B., Górecki, T. \& Namieśnik, J. (2003): Calibration of Permeation Passive Samplers with Silicone Membranes Based on Physicochemical Properties of the Analytes. - Analytical Chemistry 75(13): 3182-3192. 



\section{Sammenfatning}

\section{Passive prøvetager forsøgsundersøgelse}

Danmark, Færøerne, Norge og Sverige deltog i den fælles Oslo-Paris konvention og det internationale havforskningsråds (OSPAR/ICES) undersøgelse af passive prøvetagere (PSTS) med støtte fra Nordisk Ministerråd.

Passive prøvetagere med indbyggede performance reference stoffer (PRC) blev fremstillet på det hollandske nationale institut for kyst og marin management (RIKZ). Efter udlægning på forskellige lokaliteter i hele Nordeuropa og Australien blev de passive prøvetagere dels analyseret af nationale laboratorier, dels sendt til RIKZ for ekstraktion og analyse.

\section{Brug af passive prøvetager i de nordiske lande}

Til trods for at de første anvendelser af passive prøvetagere skete for to årtier siden, har de ikke vundet indpas i nordiske overvågningsstrategier måske med undtagelse af Norge. En kort gennemgang af eksisterende viden og anvendelse af passive prøvetagere i de nordiske lande kan findes i Annex 2.

\section{Evaluering af passive prøvetagere}

Passive prøvetagere blev udlagt på 9 lokaliteter i de nordiske lande og på Grønland, og muslinger blev indsamlet på samme lokaliteter for at sammenligne resultater fra passive prøvetagere med mussel-watch fremgangsmåden, der normalt anvendes i national overvågning. Der blev parallelt hermed indsamlet sedimenter på 6 lokaliteter, som blev analyseret med standardmetoder samt ekstraheret med passive prøvetagere for sediment.

Beregning af udvekslingsraten mellem prøvetager og vand blev beregnet af både referencelaboratoriet og de nationale laboratorier (i norden Vandforskningsinstituttet i Norge, NIVA), og varierede med en faktor 10, dels pga. en mere avancerede beregningsmetode anvendt på referencelaboratoriet, dels pga. forskel i bestemmelse af indholdet af præstationsreferencestoffer (PRC'er: deuterium-mærkede PAH og PCB'er). Beregningsmetoden for udvekslingsrater vil blive harmoniseret gennem en OSPAR/ICES guideline for passive prøvetagere.

Ved sammenligning af beregningen af vandfasekoncentrationerne af PAH mellem NIVA og referencelaboratoriet, blev der fundet op til 10 gange højere koncentrationer af referencelaboratoriet, der generelt fandt de 
højeste koncentrationer. En del af denne forskel kan tilskrives forskellen i udvekslingsrater anvendt i de to laboratorier, men også analysen af PAH'er i de passive samplere. Dette må forventes at blive forbedret med erfaring og interkalibrering af analysemetoderne. Den internationale organisation for interkalibrering af marine matricer, QUASIMEME, har allerede startet et program for interkalibrering af passive prøvetagere. Erfaringerne fra Hollands eget passive prøvetagningsovervågningsprogram viser, at reproducerbarheden for analyser af passive samplere er mindst lige så god som for mussel-watch overvågningsmetoden.

Sammenligning af indholdet af PAH'er i muslinger og den beregnede vandfasekoncentration fra passive prøvetagere indikerer en øget bioakkumulationsrate for højere oktanol-vand koefficient ( $\mathrm{K}_{\text {ow }}$, udtryk for opkoncentrering i fedtvæv). Bioakkumulationsraten varierede en faktor 10 mellem de nordiske lokaliteter, hvor de mest forurenede lokaliteter udviste de højeste bioakkumulationsrater.

Resultaterne for porevand målt med passive prøvetagere til PAH koncentrationer i sediment varierede mere end for vandfasemålingerne, men indikerede også en tendens til at stoffer med højere $\mathrm{K}_{\mathrm{ow}}$ var mere bundet til sedimentet end porevandet. Ved sammenligning mellem porevandskoncentrationer og vandfasekoncentrationer kunne det påvises, at sedimentet er en kilde til benzo(a)pyren ved NIV01, hvorimod porevand til overfladevandkoncentrationerne var tæt på 1:1, hvilket indikerer en ligevægt mellem sediment og vandfase for benzo(a)pyren. For PAH'er med lavere $\mathrm{K}_{\mathrm{ow}}$ er vandfasekoncentrationen generelt højere end koncentrationen i porevandet, hvorimod benzo(ghi)perylen og indeno (123-cd) pyren er højest i porevandet. For NER01 var sediment porevandskoncentrationen lavere end vandfasekoncentrationen, så her virker sedimentet som afløb for alle PAH'er, der er medtaget i denne undersøgelse.

Projektet har vist, at passive prøvetagere som silikoneark kan anvendes i overvågningsprogrammer, især i områder hvor muslinger er svære at finde eller har problemer med at overleve udsættelse. Hvis muslinger indsamles og passive prøvetagere udsættes på samme lokaliteter, kan der udledes lokale omsætningsfaktorer mellem "mussel-watch” og passiv prøvetager-koncentrationer, men disse kan ikke nødvendigvis anvendes på en større skala. Udviklingen af håndbog og kvalitetssikring af analyser er godt på vej, og før OSPAR indlemmer passive prøvetagere i sine overvågningsprogrammer, skal der opstilles bedømmelseskriterier for resultaterne. Disse kan udledes direkte fra vandrammedirektivets kvalitetskriterier, så inden for en tidsramme på 2-3 år kan passive prøvetagere blive en del af OSPARs overvågningsstrategi. 


\title{
Annexes
}

\author{
Annex 1: Selected acronyms
}

Organisations

ASMO Working group on Assessment and Monitoring (OSPAR)

ICES The International Council for the Exploration of the Sea

MCWG Marine Chemistry Working Group (ICES)

MON Working group on monitoring (OSPAR)

NERI National Environmental Research Institute, Aarhus University (Danmarks Miljøundersøgelser)

NIVA Norwegian Institute for Water Research (Norsk institut for vattenforskning)

NMR Nordic Council of ministers (Nordisk Ministerråd)

OSPAR Oslo-Paris Convention

PSTS Passive Sampler Trial Survey - ICES/OSPAR cooperation

RIKZ National Institute for Coastal and Marine Management (The Netherlands)

SIME Working group on substances in the marine environment (OSPAR)

WGMS Working Group on Marine Sediments in relation to pollution (ICES)

ASC Annual Science Conference (ICES)

HELCOM Helsinki Convention for the Baltic Sea

WFD Water Framework Directive (EU)

Passive sampling techniques - related acronyms

DGT Diffusive gradients in thin films (metals)

LDPE Low density polyethylene (medium-high Kow)

PDMS Silicone rubber (medium-high Kow)

PRC Polar organic chemical integrative sampler (low Kow)

SPMD Semi-permeable membrane devices (organics, medium-high Kow)

MESCO Membrane-enclosed sorptive coating sampler

TMP Tri-methyl pentane passive sampler 


\section{Substances}

BAM 2,6-dichlorobenzamide, a metabolite from the pesticide dichlobenile

DNOC 4,6-dinitro-o-cresol, a dinitrophenol pesticide: 2-methyl-4,6dinitrophenol

PAH Poly-aromatic hydrocarbons

PBDE Poly-brominated diphenyl ethers, flame retardants

PCB Polychlorinated biphenyls

TBT Tributyltin

TOC Total organic carbon 


\section{Annex 2: Use of passive samplers in the Nordic countries}

This annex summarises the use of passive samplers in the participating Nordic countries to the knowledge of the authors.

\section{Denmark}

The Danish Environmental Protection Agency funded a literature study from COWIconsult ${ }^{1}$ in 2000 (Stuer-Lauridsen \& Birkved 2000) as part of the revision of the national monitoring programme in 2003. However, passive sampling was not included in the 2004-2009 monitoring programme following these revisions. From 1995 to 1998, Stuer-Lauridsen was employed at NERI and tested passive samplers (mainly semipermeable membrane devices, SPMDs) for the monitoring of PAHs and pesticides.

Since 2004, NERI has headed the ongoing EU project NoMiracle that utilises passive samplers (silicone tubes and others) to evaluate chemical risk.

Recently a project using passive samplers to measure herbicides in seawater was performed in collaboration between NERI and Environment Centre Ringkøbing (Dahllöf et al. 2008). Polar organic chemical integrative samplers (POCIS) were used to sample herbicides in Nissum Fjord, Denmark, and detected 20 different herbicides and degradation products from farming activities around the fjord.

In non-marine areas, passive samplers have also been used, e.g. for tracking sources of pollution in groundwater (Tuxen et al. 2007).

\section{Norway}

Norway is the Nordic country with, possibly, most experience in the use, research and development of passive sampling devices. SPMD have been used at NIVA for almost a decade and regularly deployed around the coast of Norway for the monitoring of trace organic contaminants and TBT in water. They have also been applied to the monitoring of water around offshore oil and gas industry alongside biomonitoring. Calibration work has been undertaken at NIVA over the last five years to establish contaminant uptake rates for SPMD and POCIS passive sampling devices. More recently, the focus has been on using more simple polymeric materials (such as silicone, low-density polyethylene or polyoxymethylene) for the measurement of trace levels of hydrophobic contaminants in water and sediments. NIVA has also been using diffusive gradient in thin film devices (DGT) routinely for measuring pollution by metals.

\footnotetext{
${ }^{1}$ A consulting engineering company founded by Chr. Ostenfeld and W. Jønson in 1930.
} 


\section{Sweden}

A large project was conducted in Sweden in 2007 which focussed on the comparison of contaminant concentrations (non-polar, polar organics and metals) measured by a range of passive samplers (namely SPMDs, POCIS and DGTs) and those measured with spot water samplers (SWECO 2007).

The deployment of passive sampling devices on more local or regional levels demonstrated that sampling devices made of silicone tubing were able to distinguish between dioxin and furan (PCDD/F) contaminated and uncontaminated sites. These data were also used to evaluate the risk presented by PCDD/F by measuring the freely dissolved fraction, finding risk lower by a factor of 10-50 times than that expected based on more traditional measurements of total concentration of dioxins (Cornelissen et al. (2006); Broman et al. (2008)).

\section{The Faroe Islands}

Passive samplers have not previously been deployed in the Faroe Islands waters. 


\section{Annex 3: OSPAR and PSTS}

The meetings pertaining to the ICES/OSPAR PSTS are shortly described below, followed by references within the OSPAR system. Documents can be found on www.ospar.org, under meetings, together with the summary records of each meeting.

\section{OSPAR 2005}

At SIME 2005, the use of passive samplers in the Coordinated Environmental Monitoring Programme under OSPAR were recognised, and an action point was put in annex 6 - review of the CEMP.

\section{OSPAR 2006}

At SIME in March 2006, it was noted that "the use in OSPAR of passive samplers would have great potential to link status monitoring for OSPAR with compliance monitoring under the WFD” (Clause $4.15 \mathrm{~d}$ in SIME 06 summary record - referring to the chemical monitoring activity (CMA) document for WFD), and the review of passive samplers resulted in recommendation of a one-off Passive Sampler Trial Survey (PSTS). The recommendation was followed with the warning that although deployment probably was not an issue for the contracting parties, the analysis of the samplers could be a financial obstacle. Finally, a set of lead countries was invited to develop a proposal to ASMO 2006. Liaisons with HELCOM and other marine conventions by the secretariat of OSPAR were also envisioned, as well as possibilities of funding the one-off survey.

At ASMO in April 2006, the trial survey was endorsed, and the contraction parties were encouraged to support their laboratories, and the convenors to report the outcome to SIME and ASMO.

At MON in December 2006, it was noted in point d in section 5.6 of the MON 2006 summary record, that from preliminary data of the PSTS that "in the one-off survey for endosulfan additional use should be made of data from trial surveys using passive samplers". The inclusion of supplemental analytes outside of the original scope of the PSTS showed that the usefulness of passive samplers could be extended to other priority hazardous substances besides PAH and PCBs, and supplement sediment and biota analysis in the QSR 2010.

\section{OSPAR 2007}

At SIME in February 2007, the progress was reported, noting that 11 countries and 13 laboratories were participating, covering 30 sampling stations. Some samplers had already been returned to the central laboratory of the principal investigator Foppe Smedes (NL). 
At MON in December 2007, the possibility of case studies for the Quality Status Report 2010 was discussed, and the Scheldt and adjacent areas in the southern North Sea were suggested as the Scheldt contributed to pollution from highly industrialised areas, and since additional information was available from passive sampling observations and from models on transboundary transports.

\section{OSPAR 2008}

At SIME in February 2008, a new progress report on the PSTS was presented, with results of freely dissolved CBs and PAHs in water and sediments. No technical barriers were identified for water samplers, but for sediments more optimization and experience were needed, before implementation. SIME noted a great enthusiasm towards the programme and possibilities, as a tool in the monitoring toolbox. Guidelines and assessment criteria that clearly defined what monitoring using passive samplers could be used for, as well as harmonisation of different techniques, should be developed. ICES working groups WGMS and MCWG were planning to carry out further work, and SIME 2009 should review the further implementation of passive samplers in environmental monitoring.

It was also noted, that the passive samplers for water had been successfully extended to cover priority substances as lindane, chlorpyrifos, endosulfan-1, trifluralin, BDE047 and BDE099. As a result of this positive feedback, it was noted that a case study on the passive sampler survey should be included in the OSPAR Quality Status Report 2010.

At MON in November 2008, the suggested text for a case study on passive samplers was examined and in the comments, it was suggested to focus it more on the applicability and results achieved for assessment on quality status, and why the passive sampler was better or equal to existing monitoring methods. The case study was suggested to be amended along these lines, and then submitted to the drafting panel in 2009 for publication in the QSR 2010.

OSPAR 2005

\begin{tabular}{|l|l|l|l|}
\hline C8 & $\begin{array}{l}\text { Review and report on the use of } \\
\text { passive samplers for monitoring } \\
\text { of contaminants and their poten- } \\
\text { tial for use in the CEMP }\end{array}$ & $\begin{array}{l}\text { Belgium, } \\
\text { Denmark }\end{array}$ & SIME \\
& UK & \\
\hline
\end{tabular}

SIME 2005, Summary record, Annex 6, action point 
OSPAR 2006

\begin{tabular}{|l|l|l|}
\hline SIME & $\begin{array}{l}\text { Adjustment of existing CEMP } \\
\text { monitoring activities - marine } \\
\text { environmental contaminant moni- } \\
\text { toring using passive samplers }\end{array}$ & $\begin{array}{l}\text { Belgium, } \\
\text { Denmark, } \\
\text { Netherlands and } \\
\text { the UK }\end{array}$ \\
\hline SIME & $\begin{array}{l}\text { Review of the use of passive sam- } \\
\text { plers for monitoring hazardous } \\
\text { substances in the marine environ- }\end{array}$ & United Kingdom \\
& $\begin{array}{l}\text { ment around the UK during 2005 } \\
\text { ment(L) }\end{array}$ & \\
\hline
\end{tabular}

SIME 2006 meeting documents; see also summary record clause 4.15.

\begin{tabular}{|l|l|l|}
\hline ASMO & $\begin{array}{l}\text { Review of the CEMP - supporting } \\
\text { activities. Progress by ICES Work- } \\
\text { ing Groups on a trial survey and } \\
\text { intercalibration of passive sam- } \\
\text { pling }\end{array}$ & $\begin{array}{l}\text { Belgium, } \\
\text { Denmark, the } \\
\text { Netherlands } \\
\text { and the UK }\end{array}$ \\
\hline
\end{tabular}

ASMO 2006 meeting document; see also summary record.

MON 2006 summary record, section 5.6.

OSPAR 2007

\begin{tabular}{|l|l|l|}
\hline SIME & Marine environmental & Chairs of ICES \\
& contaminant monitoring using & MCWG and \\
& passive samplers & WGMS, on \\
& & behalf of the \\
& & PSTS Steering \\
& Group \\
\hline
\end{tabular}

OSPAR 2008

\begin{tabular}{|c|c|c|}
\hline $\begin{array}{l}\text { SIME } \\
\text { 08/04/04-E*(L) }\end{array}$ & $\begin{array}{l}\text { Report to SIME on the ICES } \\
\text { Passive Sampling Trial } \\
\text { Survey/Intercalibration }\end{array}$ & $\begin{array}{l}\text { The } \\
\text { Netherlands, on } \\
\text { behalf of the } \\
\text { PSTS Steering } \\
\text { Group }\end{array}$ \\
\hline $\begin{array}{l}\text { SIME } \\
\text { 08/04/04-Add.01- } \\
\mathrm{E}^{*}(\mathrm{~L})\end{array}$ & $\begin{array}{l}\text { Note to SIME on the contribution } \\
\text { from the ICES Passive Sampling } \\
\text { Trial Survey/ intercalibration } \\
\text { (PSTS) to surveys of emerging } \\
\text { (new) contaminants }\end{array}$ & $\begin{array}{l}\text { The Netherlands } \\
\text { and the UK, on } \\
\text { behalf of the } \\
\text { PSTS Steering } \\
\text { Group }\end{array}$ \\
\hline
\end{tabular}

OSPAR 2008

\begin{tabular}{|l|l|l|}
\hline MON & $\begin{array}{l}\text { Case study: Monitoring with pas- } \\
\text { sive samplers }\end{array}$ & The Netherlands \\
\hline
\end{tabular}




\section{Annex 4: Program for Passive Sampler møde på Søminestationen ved Holbæk (Danmark)}

\section{Deltagere:}

Martin M. Larsen, DMU, AU, Danmark

Kristoffer Naes, NIVA, Norge

Elisabeth Nyberg, NRM, Sverige

Katrin Hoydal, US, Færøerne

\section{Mandag 10/10-2008}

Ankomst og indkvartering på Søminestationen.

\section{2:30 - 13:00 Frokost}

13:00 - 15:00 Anvendelsen af passive samplere i de nordiske lande.

- oplæg fra de enkelte lande om hvor passive samplere har været á max 30 minutter, efterfulgt af diskussion

15:00 - 16:00 Passive sampleres placering i OSPAR-systemet - evt. status på EU plan

16:00 - 17:00 Første kik på rapporten, gennemgang af Passive Sampling Trial Survey

17:00 - 18:00 Socialt indslag: Fraser slægtens historie med indlagt sækkepibe spil

Herefter aftensmad og samling af input fra de enkelte lande til rapporten.

Tirsdag 11/10

8:00 - 9:00 Morgenmad

9:00 - 11:00 Gennemlæsning af revideret udkast af rapport, diskussion af politikken og mulighederne i de enkelte lande for at fremme anvendelsen af passive samplere

11:00 - 11:30 Kaffepause

11:30 - 13:00 Diskussion af det videre arbejde med rapporten, evt. uddelegering af opgaver

13:00 - 14:00 Frokost

14:00 - 15:00 Afrunding og oprydning 


\title{
Annex 5: The participating institutions and examples of passive sampler experiences in the Nordic countries
}

\author{
Denmark - National Environmental Research \\ Institute, Aarhus University (NERI)
}

In 1986, the first Danish eutrophication plan was initiated, and the Danish Ministry of the Environment's laboratory for pollution at sea, Havforureningslaboratoriet, was made responsible for the monitoring programme. In 1989, Havforureningslaboratoriet was joined with 4 other laboratories under the Ministry of the Environment into a new national institute for environmental research: NERI.

NERI was responsible for the national monitoring programmes until August 2007, where responsibility was transferred to a monitoring secretariat within the Agency for Spatial and Environmental Planning, Ministry of the Environment. NERI is still responsible for monitoring of the open sea, and the national focal point for marine data is situated at NERI. Reporting of monitoring data to ICES is also part of NERI's responsibility.

The Department of Marine Ecology has participated in several HELCOM, OSPAR and ICES working groups on pollution on behalf of Denmark.

\section{Examples of Danish passive sampler experience}

The first to use passive samplers at NERI was Stuer-Lauridsen et al. (1996), followed by a number of posters concerning the use of SPMDs for measuring PAHs and pesticides in different water matrices.

NERI is involved in research in passive sampler techniques by Phillip Mayer (EU project NoMiracle co-ordinated by Dr. Hans Løkke, NERI started in 2004). NoMiracle will help increase knowledge on the transfer of pollutants between different environmental compartments, and on the impact of cumulative stressors, including chemical mixtures. This will facilitate human and ecosystem health monitoring by providing the link with information concerning the condition of air, water, soil and urban environment. By developing and using improved assessment tools and novel models, the project will quantify and aim at reducing uncertainty in current risk assessment and screening methodologies, for example by improving the scientific basis for setting safety factors. The new methods will take into account geographical, ecological, social and cultural differences across Europe. The passive sampling techniques are central in answering two key questions: Can better understanding be found of how living organisms absorb chemicals found in their environment? And can we describe complex exposure situations by simple diagnostic measurements? A number of peer reviewed articles have been published, e.g. Liu et al. (2007), Mayer et al. (2008), Reichenberg et al. (2008), Jahnke et al. (2008), Cornelissen et al. 
(2008) and Ossiander et al. (2008), and more information can be found at the NoMiracle website (http://nomiracle.jrc.ec.europa.eu).

In 2007, the Environment Centre Ringkøbing and NERI used passive samplers to prove the presence of pesticides in Nissum Fjord,Denmark, using POSIC samplers for polar substances in marine areas (Dahllöf et al. 2008). The project showed the presence of 12 herbicides and 8 degradation products, including the now forbidden atrazine, 4-nitrophenol, BAM, DNOC and isoproturon. The aim of the project was to investigate if herbicides could be found, that could explain the lack of eelgrass recolonisation in Nissum Fjord. No calibration of the samplers was performed, but using freshwater uptake rates derived from Zbiegala et al. (2003) and Vrana et al. (2006), rough estimates of diuron and isoproturon concentrations were obtained, indicating levels previously shown to have effects on growth of eelgrass in combination studies.

A new project involving POSIC samplers in combination with silicone rubbers is planned for 2009, to investigate endocrine disrupters in Danish streams. It will be combined with investigation of biological effects in caged freshwater mussels at the same positions as the passive samplers, and in vitro tests on mammalian cells from extracts of the passive samplers. Analyses of the passive samplers include phthalates, phenols, PFAS, organotin, pesticides and estrogenic substances.

Passive samplers corresponding to the PSTS method have been deployed in Greenland in 2007 and 2008, but have not been analysed yet.

\section{Norwegian Institute for Water Research (NIVA)}

NIVA is Norway's leading multidisciplinary independent research institute in the field of use and protection of water bodies and water quality, in fresh and marine waters. NIVA is a foundation established on 1 July 1958. Its board is appointed by the Ministry of the Environment (MD), the Research Council of Norway and employees at NIVA. The head office is in Oslo with regional offices in Hamar, Grimstad, Bergen and Trondheim, and a marine research station near Drøbak. To strengthen NIVA's activities and to provide a better service to its partners in Poland and Europe, NIVA has now established a subsidiary in Gdansk, Geomor-NIVA.

NIVA has been involved in environmental surveillance and monitoring programmes such as the OSPAR monitoring of the North Sea, EEA and EU environmental centre. NIVA has been contributing to the JAMP monitoring programme as part of OSPAR for many years with a view to assess levels and effect of contaminant present in waters on the coast of Norway. In Norway, this programme started in 1981. 


\section{Examples of Norwegian passive sampler experience}

Semi-permeable membrane devices and Polar Organic Compound Integrative Samplers (POCIS) have been deployed alongside biomonitoring techniques for the monitoring of waters close to offshore oil and gas installations over the last few years. They were used for the monitoring of PAHs as well as a whole range of alkylphenols. It was in some cases possible to use the extract from passive sampling devices in toxicity assessment using a range of bioassays.

A very promising project recently undertaken by NIVA (Ian Allan, Eirik Fjeld and Øyvind Kaste) and commissioned by the Norwegian State Pollution Control Authority (SFT) aimed to develop and evaluate a number of tools including passive sampling devices to measure trace metallic and organic contaminant concentrations in rivers (Allan et al. 2006). The long-term objective was to enable the use and future integration of these methods into the OSPAR comprehensive study on riverine inputs and direct discharges (RID) monitoring programme to estimate fluxes of trace contaminant from Norwegian rivers into the North Sea. It was assumed that these techniques would help refine and improve estimate of fluxes of contaminant through the improvement in limits of detections that can be achieved with these tools. A range of passive samplers (SPMDs, LDPE membranes and silicone strips produced in-house) were deployed in the Drammenselva River to measure dissolved contaminant concentrations (PAHs, PCBs and PBDEs) and data were compared with those obtained through large volume water sampling, and the monitoring contaminant levels in the suspended particulate matter (SPM) phase. In this way, it was possible to estimate SPM-water partition coefficients for a range of contaminants and limits of detection for PCB, and PBDEs were in the low pg/l range (total water concentrations). Excellent agreement between data obtained with the three types of passive sampling devices was observed both in terms of contaminant masses absorbed but also in terms of PRC data.

\section{The Swedish Museum of Natural History (NRM)}

The Department of Contaminant Research (DCR) at the Swedish Museum of Natural History has been active for over four decades. It was formed in the early 1960s in response to the discovery of negative environmental trends in Sweden - dramatic declines in the populations of many bird species, the grey seals of the Baltic Sea and otters along inland waters.

During the 1970s, DCR launched studies of transport mechanisms and conducted Sweden's first programmes for monitoring environmental contaminants, based on OECD guidelines. DCR has also built up the world's first environmental specimen bank, containing samples of certain plants and soft organs of exposed animal species. Today, the museum's Environmental Specimen Bank (ESB) contains over 290,000 environmental 
samples preserved mainly by freezing; some 9,000 new samples are added every year and around 3,000 are analysed.

Since the 1980s, DCR has been responsible for the Swedish national programmes for monitoring of contaminants in marine, limnic and terrestrial biota, as well as the populations of top consumers in marine ecosystems, including seals and white-tailed eagles. The programmes are financed by the Swedish Environmental Protection Agency.

\section{Examples of Swedish passive sampler experience}

Screening (SWECO VIAK on behalf of the Swedish EPA):

Passive samplers were used in the nationwide screening of WFD priority substances (2007) in limnical and costal surface waters.

Chemical analyses were performed on both unfiltered and filtered water and passive samplers were used to determine the monthly mean at the localities sampled. Three types of passive samplers were used in the project:

1. SPMD (Semi-Permeable Membrane) - for sampling of non-polar organic substances

2. DGT (Diffusive Gradient in Thin film) for sampling of metals

3. POCIS (Polar Organic Chemical Integrative Sampler) for sampling of polar organic substances.

Regional (examples of usage):

Risk evaluation of leakage of dioxins from contaminated areas (due to the usage of PCP) - Gerard Cornelissen, Dag Broman et al.

Aim: To improve humane and ecotoxicological risk evaluation methodology for dioxins and thereby facilitate the prioritisation of after treatment at contaminated sites.

Method: Measurements of the freely dissolved fraction of dioxins by passive samplers (simple plates of polymeric material) and of the total concentration in the soil at a dioxin contaminated site (Marieberg) to evaluate how much of the dioxins that are bound to black carbon.

Outcome: The ecotoxicological risk evaluated by measuring the freely dissolved fraction with passive samplers is about a factor 10-50 times smaller than expected from traditional measurements based on total concentration of dioxins.

PCDD/PCDF concentrations in the water close to wood and paper mills - report from measurements with sediment traps and passive samplers - Gerard Cornelissen, Dag Broman et al.

Aim: To investigate if there are significant ongoing PCCD/F emissions from Swedish wood and paper mills investigated in the study.

Method: Measurements of the time integrated concentration of PCDD/F by passive samplers made of a thin silicone tube (PDMS, polydimethylsiloxane), which earlier have been used in studies from the 
harbour in Oslo and the Frierfjord in Norway. The level of PCDD/F in SPM was also measured.

Outcome: No significant differences were found for the timeintegrated concentration of freely dissolved PCDD/F between background sites, wood and paper mill sites and sites affected by "other industry". The concentrations in SPM were significantly higher at wood and paper mill sites than at background sites.

Chalmers University of Technology, Göteborg, participated in the work on Chemcatcher ${ }^{\mathrm{TM}}$, headed by Greg Morrisson, during an EU project entitled STAMPS (and later SWIFT), which was led by the University of Portsmouth (UK) focussing on the development of a sampling device for metals (http://www.port.ac.uk/departments/academic/biology/ research/marinesciences/aquaticenvironmentalchemistry/). The latest development on the Chemcatcher ${ }^{\mathrm{TM}}$ has been described in Allan et al. (2007) on the use of Chemcatcher ${ }^{\mathrm{TM}}$ and DGT passive samplers for TWA sampling of metals, and Vrana et al. (2007) on the use of Chemcatcher ${ }^{\mathrm{TM}}$ for hydrophobic organic contaminants, with modelling and calibration as focus.

\section{Faroe Islands - Environment Agency (US)}

The research department of the Environment Agency on the Faroe Islands was formerly a part of the Food, Environmental and Veterinary Agency but was moved together with the environmental department to the new institution "Environment Agency" at the end of 2007. The department has been responsible for performing and developing the monitoring of contaminants in the environment since the establishment in 1995. The monitoring includes terrestrial, freshwater and marine environment with focus on long-range transported contaminants. The department also performs analyses of local pollution, e.g. around harbours or in connection with oil spills.

No experience with passive samplers in the Faroe Islands. 



\section{Bilag}

Data sheets reported to PSTS (water 1-8, sediment 1-5) 


\section{Water sampling}

Who filled this form

email

Telephone (international)

Participant

Participant code \#

Station code \#

Heading line

Arrival date of PS material/mussels

Coordinate $x$ (decimal degrees) \#

Coordinate y (decimal degrees) \#

Water depth

Deployment depth

Data of deployment.\#

Water Temp on deployment $\left({ }^{\circ} \mathrm{C}\right)$

Air Temp on deployment $\left({ }^{\circ} \mathrm{C}\right)$

Salinity on deployment (o/oo)

SPM or Secci on deployment

Exposed (d)

Data of recovery.\#

Water Temp on recovery $\left({ }^{\circ} \mathrm{C}\right)$

Air Temp on recovery $\left({ }^{\circ} \mathrm{C}\right)$

Salinity on recovery (o/oo)

SPM or Secci on recovery

Decribe fouling in a comment

Duplicate send to REF lab.

Sampler cage numbe

Sheet holder number

Sheet Bottle number

Sheet weight after extraction \#

Number of mussels

Average shell length $(\mathrm{mm})$

Average dry flesh weight

Extractable lipid

hexachlorobenzene

2,2',5-trichlorobiphenyl

2,4,4'-trichlorobiphenyl

2,4',5-trichlorobiphenyl

2,2 ',3,5'-tetrachlorobiphenyl

2,2',5,5'-tetrachlorobiphenyl

2,2',4,5,5'-pentachlorobiphenyl

2,3,3',4,4'-pentachlorobiphenyl

2, 3', 4, 4' 5-pentachlorobiphenyl

$2,2^{\prime}, 3,4,4^{\prime}, 5^{\prime}$-hexachlorobiphenyl

2,2',4,4',5,5'-hexachlorobiphenyl

$2,2^{\prime}, 3,3$ ', $4,4^{\prime}, 5$-heptachlorobiphenyl

$2,2^{\prime}, 3,4,4^{\prime}, 5,5^{\prime}$-heptachlorobiphenyl

$2,2^{\prime}, 3,4^{\prime}, 5,5^{\prime}, 6$-heptachlorobiphenyl

2,6-Dichorobiphenyl

3,5-Dichorobiphenyl

2,3,4-trichorobipheny

2,4,6-trichorobipheny

2, 2, 4,6-tetrachorobipheny

3,3',4,6-tetrachorobiphenyl

2,3,3',4-tetrachorobiphenyl

2,2',4,6,6'-pentachorobipheny

2,2',3,4,6,6'-pentachorobiphenyl

$2,2^{\prime}, 3,4,4^{\prime}, 5,6,6^{\prime}$-octachlorobiphenyl

naphthalene

acenaphthene

acenaphthylene

fluorene

phenanthrene

anthracene

fluoranthene

pyrene

benzo[a]anthracene

chrysene

benzo[e]pyrene

benzo[a]pyrene

benzo[ghi]perylene

indeno[1,2,3-cd]pyrene

Naphtalene-D8

Fluorene-D10

Phenanthrene D10

Fluoranthene-D10

Chrysene-D10

Benz(e)pyrene-D12

Perylene-D12

Coronene-D12

Type ICES code in righthand cell

$\begin{array}{ll}\text { Name } & \text { Martin M. Larsen } \\ \text { Email } & \text { mml@dmu.dk } \\ \text { Tel } & 4546301259 \\ \text { Institute } & \text { NERI, Denmark } \\ \text { PartC } & \text { NERI, Denmark } \\ \text { StatC } & \text { NER01 }\end{array}$

StatC

NER01

\begin{tabular}{|c|c|c|c|c|c|c|c|}
\hline Empty06 & Sample & Reference & $\begin{array}{l}\text { Procedural } \\
\text { Blank }\end{array}$ & $\begin{array}{l}\text { Sample for } \\
\text { ref lab }\end{array}$ & $\begin{array}{l}\text { Mussel } \\
\text { Start }\end{array}$ & $\begin{array}{l}\text { Mussel after } \\
\text { or local }\end{array}$ & $\begin{array}{l}\text { Free diss } \\
\text { Water } \\
\text { conc. }\end{array}$ \\
\hline DDxArr & 28-Sep-06 & & & & & Sand Gaper & \\
\hline XCrd & 55.439 & & & & & & \\
\hline Ycrd & 10.427 & & & & & & \\
\hline WTRxDepth & 0.7 & & & & & 0.7 & \\
\hline ExpxDepth & 0.2 & & & & & 0.7 & \\
\hline
\end{tabular}

ExpxDepth

Empty01

DDxStart

TwtrxStart

TairxStart

SALXStart

SPMXStart

Empty02

Days

DDxEnd

TwtrxEnd

TairxEnd

SALXEnd

SPMXEnd

Fouling

Empty04

DDxRef

Empty05

$\begin{array}{lllll}\text { SCXNr } & \text { K7 } & & & \text { K7 } \\ \text { SHXNr } & \text { H86 } & & & \text { H46 } \\ \text { BotxNr } & \text { Not used } & \text { Not used } & \text { Not used } & \text { Not used } \\ \text { MA } & & 7.07 & & \end{array}$

MusselNr

ShellxL

FleshDry

Exlip

HCB

CB18

CB28

CB31

CB44

CB52

CB101

CB105

CB118

CB138

CB153

CB170

CB180

\begin{tabular}{l|r} 
CB187 & \\
CB10 & 23256
\end{tabular}

CB14

CB21

CB30

CB50

CB78

CB55

CB104

CB145

CB204

Nap

Acne

Acnle

$\mathrm{Fle}$

$\mathrm{Fle}$

Ant

Ant

Pyr

Pyr

Baa

Chr

$\mathrm{BeP}$

BghiP

ICDP

NAPXD8

FLEXD10

PAxD10

FluxD10

ChrxD12

BePxD12

PexD12

CORXD12

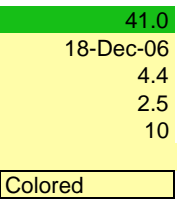

local

7.7

$-06$

4.4

Colored

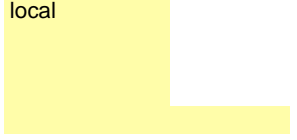

18-Dec-06

45.33

$\begin{array}{ll}1.4 & 0.19\end{array}$

0.41

0.36
0.26

0.44

0.50

0.28

0.49

0.64

0.79

$-0.10$

0.22

0.27

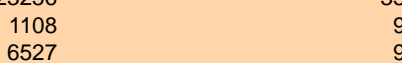

4212

2095

$1417-10$

1923

786

1234

7

$\begin{array}{rr}145 & 24 \\ 86 & -10\end{array}$

$31-10$

$118-10$

382
94

$\begin{array}{rr}94 & -10 \\ 1144 & 14\end{array}$

962

$107-10$

$\begin{array}{rr}64 & -10 \\ 29 & -10\end{array}$

$\begin{array}{ll}29 & -10 \\ 19 & -10\end{array}$

19
15

-10
12
40

$\begin{array}{ll}12 & -10 \\ 40 & -10\end{array}$

$84-10$

$-10$

$\begin{array}{rr}157 & -10 \\ 97 & -10\end{array}$

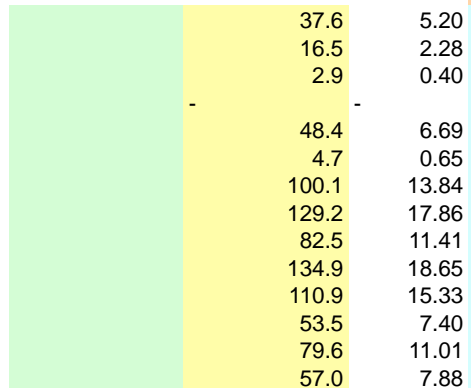

Macintosh HD:Users:mml:F-drev:grndstof:Tilbud:NMR_PassiveSamplers:final_submission:WTRxNER01.xls 


\section{Water sampling}

Who filled this form

email

Telephone (international)

Participant

Participant code \#

Station code \#

Heading line

Arrival date of PS material/mussels

Coordinate $x$ (decimal degrees) \#

Coordinate y (decimal degrees) \#

Water depth

Deployment depth

Data of deployment.\#

Water Temp on deployment $\left({ }^{\circ} \mathrm{C}\right)$

Air Temp on deployment $\left({ }^{\circ} \mathrm{C}\right)$

Salinity on deployment (o/oo)

SPM or Secci on deployment

Exposed (d)

Data of recovery.\#

Water Temp on recovery $\left({ }^{\circ} \mathrm{C}\right)$

Air Temp on recovery $\left({ }^{\circ} \mathrm{C}\right)$

Salinity on recovery (o/oo)

SPM or Secci on recovery

Decribe fouling in a comment

Duplicate send to REF lab.

Sampler cage number

Sheet holder number

Sheet Bottle number

Sheet weight after extraction \#

Number of mussels

Average shell length $(\mathrm{mm})$

Average dry flesh weight

Extractable lipid

hexachlorobenzene

2,2',5-trichlorobiphenyl

2,4,4'-trichlorobiphenyl

2,4',5-trichlorobiphenyl

$2,2,3,5^{\prime}$-tetrachlorobiphenyl

2,2',5,5'-tetrachlorobiphenyl

2,2',4,5,5'-pentachlorobiphenyl

2,3,3',4,4'-pentachlorobiphenyl

2, 3', 4, 4' 5-pentachlorobiphenyl

$2,2^{\prime}, 3,4,4^{\prime}, 5^{\prime}$-hexachlorobiphenyl

2,2',4,4',5,5'-hexachlorobiphenyl

$2,2^{\prime}, 3,3$ ', $4,4^{\prime}, 5$-heptachlorobiphenyl

$2,2^{\prime}, 3,4,4^{\prime}, 5,5^{\prime}$-heptachlorobiphenyl

$2,2^{\prime}, 3,4^{\prime}, 5,5^{\prime}, 6$-heptachlorobiphenyl

2,6-Dichorobiphenyl

3,5-Dichorobiphenyl

2,3,4-trichorobipheny

2,4,6-trichorobipheny

2, 2, 4,6-tetrachorobipheny

3,3',4,6-tetrachorobiphenyl

2,3,3',4-tetrachorobiphenyl

2,2',4,6,6'-pentachorobipheny

2,2',3,4,6,6'-pentachorobiphenyl

$2,2^{\prime}, 3,4,4^{\prime}, 5,6,6^{\prime}$-octachlorobiphenyl

naphthalene

acenaphthene

acenaphthylene

fluorene

phenanthrene

anthracene

fluoranthene

pyrene

benzo[a]anthracene

chrysene

benzo[e]pyrene

benzo[a]pyrene

benzo[ghi]perylene

indeno[1,2,3-cd]pyrene

Naphtalene-D8

Fluorene-D10

Phenanthrene D10

Fluoranthene-D10

Chrysene-D10

Benz(e)pyrene-D12

Perylene-D12

Coronene-D12

Type ICES code in righthand cell

\begin{tabular}{ll} 
Name & Martin M. Larsen \\
Email & mml@dmu.dk \\
Tel & 4546301259 \\
Institute & NERI, Denmark \\
PartC & NERI, Denmark \\
StatC & NER02 \\
\hline
\end{tabular}

StatC

$\mathrm{NERO2}$

\begin{tabular}{lr} 
Empty06 & Sample \\
\hline DDxArr & $28-S e p-06$ \\
XCrd & 55.479 \\
Ycrd & 10.517 \\
WTRxDepth & 0.7 \\
ExpxDepth & 0.2 \\
Empty01 & \\
DDxStart & $7-$ Nov-06 \\
TwtrxStart & 8.2 \\
TairxStart & 10 \\
SALXStart & 19.4 \\
SPMXStart & \\
Empty02 & \\
Days & 35.0 \\
DDxEnd & $12-$ Dec-06 \\
TwtrxEnd & 6.5 \\
TairxEnd & 2.5 \\
SALxEnd & 20 \\
SPMXEnd & \\
Fouling & Colored \\
\hline
\end{tabular}

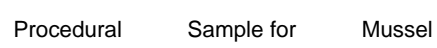

Blank

5.479
0.517
0.7

0.7

-06

8.2
10

19.4

Empty04

Empty04

Empty05

$\begin{array}{lllll}\text { SCXNr } & \text { K24 } & & & \text { K24 } \\ \text { SHXNr } & \text { H33 } & & & \text { H34 } \\ \text { BotxNr } & \text { Not used } & \text { Not used } & \text { Not used } & \text { Not used } \\ \text { MA } & & 6.98 & & \end{array}$

MusselNr

ShellxL

FleshDry

Exlip

HCB

CB18

CB28

CB31

CB44

CB52

CB101

CB105

CB118

CB138

CB153

CB170

CB180

CB187

CB10
CB14

CB14

CB30

CB50

CB78

CB55

CB104

CB145

CB204

Nap

Acne

Acnle

Fle

PA

Ant

Flu

Pyr
Baa

Chr

BeP

BaP

BghiP

ICDP

NAPxD8

FLExD10

PAxD10

FluxD10

ChrxD12

BePxD12

PexD12

$\begin{array}{ll}\text { Sample for } & \text { Musse } \\ \text { ref lab } & \text { Start }\end{array}$
Mussel after

or local

Blue Mussels

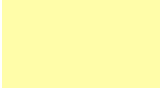

local

31-Oct-06

Colored

Slightly colored
Water

conc. 
Who filled this form

email

Martin M. Larsen

Email mml@dmu.dk

Telephone (international)

Participant

Participant code \#

Station code \#

Heading line

Arrival date of PS material/mussels

Coordinate $x$ (decimal degrees) \#

Coordinate y (decimal degrees) \#

Water depth

Deployment depth

Data of deployment.

Water Temp on deployment $\left({ }^{\circ} \mathrm{C}\right)$

Air Temp on deployment $\left({ }^{\circ} \mathrm{C}\right)$

Salinity on deployment (o/oo)

SPM or Secci on deployment

Exposed (d)

Data of recovery.\#

Water Temp on recovery $\left({ }^{\circ} \mathrm{C}\right)$

Air Temp on recovery $\left({ }^{\circ} \mathrm{C}\right)$

Salinity on recovery $(\mathrm{o} / \mathrm{oo})$

SPM or Secci on recovery

Decribe fouling in a comment

Duplicate send to REF lab.

Sampler cage number

Sheet holder number

Sheet Bottle number

Sheet weight after extraction \#

umber of mussels

Average shell length ( $\mathrm{mm}$ )

Average dry flesh weight

Extractable lipid

hexachlorobenzene

2,2',5-trichlorobiphenyl

2,4,4'-trichlorobiphenyl

2,4',5-trichlorobiphenyl

2,2',3,5'-tetrachlorobiphenyl

2,2',5,5'-tetrachlorobiphenyl

2,2',4,5,5'-pentachlorobipheny

2,3,3',4,4'-pentachlorobiphenyl

2,3',4,4',5-pentachlorobiphenyl

2,2',3,4,4',5'-hexachlorobiphenyl

$2,2^{\prime}, 3,3^{\prime}, 4,4^{\prime}, 5$-heptachlorobiphenyl

$2,2,3,4,4^{\prime}, 5,5^{\prime}$-heptachlorobiphenyl

$2,2^{\prime}, 3,4^{\prime}, 5,5^{\prime}, 6$-heptachlorobiphenyl

2,6-Dichorobiphenyl

3,5-Dichorobiphenyl

2,3,4-trichorobiphenyl

2,4,6-trichorobiphenyl

,2, , 4,6-tetrachorobiphenyl

3,3',4,6-tetrachorobiphenyl

2,3,3,4-tetrachorobiphenyl

2,2',4,6,6'-pentachorobiphenyl

2,2',3,4,6,6'-pentachorobiphenyl

2,2',3,4,4',5,6,6'-octachlorobiphenyl

naphthalene

acenaphthene

acenaphthylene

luorene

phenanthrene

anthracene

fluoranthene

pyrene

benzo[a]anthracene

chrysene

benzo|elpyrene

benzo[a]pyrene

benzo|ghilperylene

indeno[1,2,3-cd]pyrene

Naphtalene-D8

Fluorene-D10

Phenanthrene D10

Fluoranthene-D10

Chrysene-D10

Benz(e)pyrene-D12

Perylene-D12

Coronene-D12

Type ICES code in righthand cell

Type ICES code in righthand cell

Type ICES code in righthand cell

Type ICES code in righthand cell

Type CES code in righthand cell

ICES code in righthand cell

Type ICES code in righthand cell

Type ICES code in righthand cell

Type ICES code in righthand cell

Type ICES code in righthand cell

Type ICES code in

Type ICES code in righthand cell

Type ICES code in righthand cell

Type ICES code in righthand cell

Type ICES code in righthand cell

Type ICES code in righthand cell

Tel 4546301259

Institute NERI, Denmark

PartC NERI, Denmark
NERO3

Empty01

DDxStart

TwtrxStart

TairxStart

SALXStart

SPMXStart

Empty02

Days

DxEnd

TwtrxEnd

airxEnd

SALXEnd

SPMXEnd
Fouling

Empty04

DDRef

Empty05

11-Dec-06

7.8
8.5
23

Slightly colored

MA

MusselNr

ShellxL

FleshDry

Exlip

CB18
CB28

CB28

CB31

CB44

CB52
CB101

CB105

B118

CB138

CB153

CB170

CB180

B187

CB10

B14

CB21
CB30
CB50

CB50
CB78

CB78
CB55

CB104

CB145

CB204

Nap

Nap
Acne
Acnle

Acnle

PA

Ant

Flu
Pyr

Pyr

Baa

Chr

BaP

BghiP

ICDP

NAPXD8
FLExD10

FLExD10

FluxD10

ChrxD12

BePxD12

PexD12

CORxD12

BBF

DBAHA

DBAHA
DRYWT

DRYWT
BDE47

BDE99

BDE100

BDE153

BDE154

HBCD

$\mathrm{HCHA}$

$\mathrm{HCHB}$

$\mathrm{HCHD}$

DDEPP

TDEPP

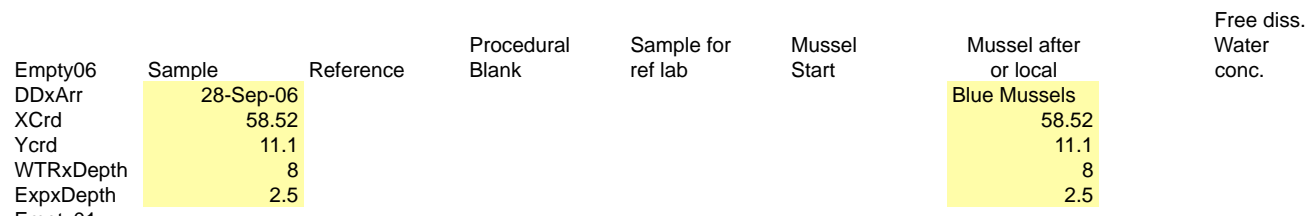

$7 \mathrm{~m}$
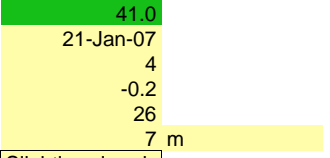

\begin{tabular}{|c|c|c|c|c|}
\hline $\mathrm{SCxNr}$ & K17 & & & K17 \\
\hline $\mathrm{SHxNr}$ & & & & $\mathrm{H} 53+\mathrm{H} 60$ \\
\hline $\begin{array}{l}\text { BotxNf } \\
\text { MA }\end{array}$ & Not used & Not used & Not used & Not used \\
\hline
\end{tabular}

Colored
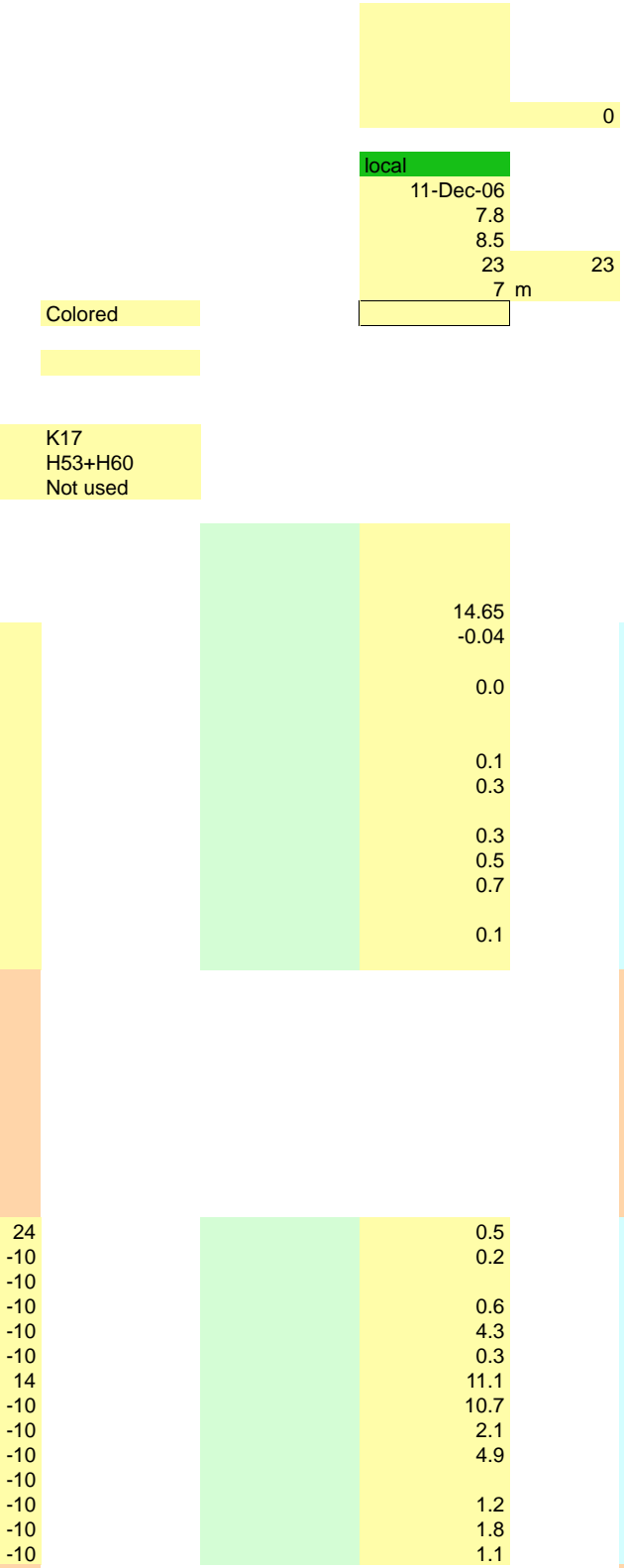
Who filled this form

email

Martin M. Larsen

Email mml@dmu.dk

Telephone (international)

Participant

Participant code \#

Station code \#

Heading line

Arrival date of PS material/mussels

Coordinate $x$ (decimal degrees) \#

Coordinate y (decimal degrees) \#

Water depth

Deployment depth

Data of deployment.

Water Temp on deployment $\left({ }^{\circ} \mathrm{C}\right)$

Air Temp on deployment $\left({ }^{\circ} \mathrm{C}\right)$

Salinity on deployment (o/oo)

SPM or Secci on deployment

Exposed (d)

Data of recovery.\#

Water Temp on recovery $\left({ }^{\circ} \mathrm{C}\right)$

Air Temp on recovery $\left({ }^{\circ} \mathrm{C}\right)$

Salinity on recovery $(\mathrm{O} / \mathrm{oo})$

SPM or Secci on recovery

Decribe fouling in a comment

Duplicate send to REF lab.

Sampler cage number

Sheet holder number

Sheet Bottle number

Sheet weight after extraction \#

umber of mussels

Average shell length ( $\mathrm{mm}$ )

Average dry flesh weight

Extractable lipid

hexachlorobenzene

2,2',5-trichlorobiphenyl

2,4,4'-trichlorobiphenyl

2,4',5-trichlorobiphenyl

2,2',3,5'-tetrachlorobiphenyl

2,2',5,5'-tetrachlorobiphenyl

2,2',4,5,5'-pentachlorobipheny

2,3,3',4,4'-pentachlorobipheny

2,3',4,4',5-pentachlorobiphenyl

2,2',3,4,4',5'-hexachlorobiphenyl

$2,2^{\prime}, 3,3^{\prime}, 4,4^{\prime}, 5$-heptachlorobiphenyl

$2,2,3,4,4^{\prime}, 5,5^{\prime}$-heptachlorobiphenyl

$2,2^{\prime}, 3,4^{\prime}, 5,5^{\prime}, 6$-heptachlorobiphenyl

2,6-Dichorobiphenyl

3,5-Dichorobiphenyl

2,3,4-trichorobiphenyl

, , 4,6-trichorobiphenyl

2, 2',4,6-tetrachorobiphenyl

3,3',4,6-tetrachorobiphenyl

2,3,3,4-tetrachorobiphenyl

2,2',4,6,6'-pentachorobiphenyl

2,2',3,4,6,6'-pentachorobiphenyl

2,2',3,4,4',5,6,6'-octachlorobiphenyl

naphthalene

acenaphthene

acenaphthylene

luorene

phenanthrene

anthracene

fluoranthene

pyrene

benzo[a]anthracene

chrysene

benzo|elpyrene

benzo[a]pyrene

benzo|ghilperylene

indeno[1,2,3-cd]pyrene

Naphtalene-D8

Fluorene-D10

Phenanthrene D10

Fluoranthene-D10

Chrysene-D10

Benz(e)pyrene-D12

Perylene-D12

Coronene-D12

Type ICES code in righthand cell

Type ICES code in righthand cell

Type ICES code in righthand cell

Type ICES code in righthand cell

Type CES code in righthand cell

ype ICES code in righthand cell

Type ICES code in righthand cell

Type ICES code in righthand cell

Type ICES code in righthand cell

Type ICES code in righthand cell

Type

(n)

Type ICES code in righthand cell

Type ICES code in righthand cell

Type ICES code in righthand cell

Type ICES code in righthand cell

Type ICES code in righthand cell

Tel

Institute NERI, Denmark

PartC NERI, Denmark

StatC NER04

DDRef

MusselNr

ShellxL

FleshDry

Exlip

CB18

CB18

CB28

CB31

CB44

CB52

CB101

CB105
CB118

CB138

CB153

CB170

CB180

CB187

CB187

CB10

B14

CB21

CB30
CB50

CB50
CB78

CB78
CB55

CB104

CB145

CB204

Nap

Acne

Acnle

$\mathrm{Fle}$

PA

Ant

Flu

Pyr

Baa

Chr

BeP

Bapip

Bghip

NAPxD8

FLEXD10

PAXD10

FluxD10

ChrxD12

BePxD12

PexD12

CORxD12

BBF

BKF

DBAHA
DRYWT

DRYWT
BDE47

BDE99

BDE100

BDE153

BDE154

HBCD

$\mathrm{HCHA}$

HCHB

HCHD

DDEPP

TDEPP

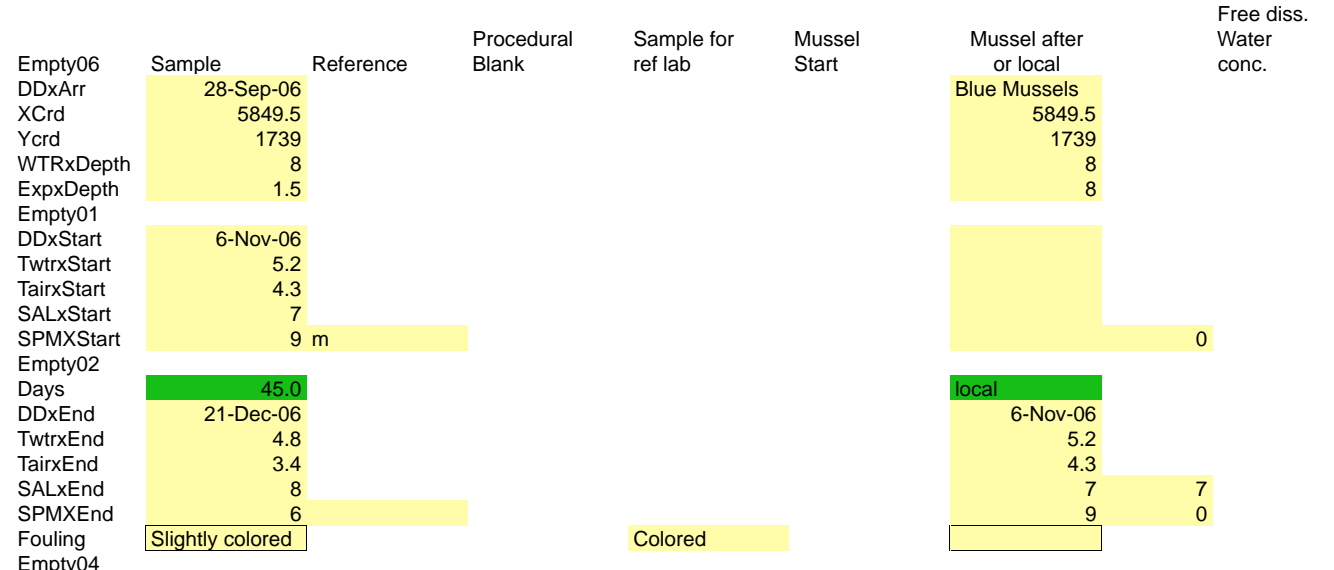

\begin{tabular}{|c|c|c|c|c|}
\hline $\begin{array}{l}\mathrm{SCxNr} \\
\text { SHXNr }\end{array}$ & K18 & & & $\begin{array}{l}\mathrm{K} 18 \\
\mathrm{H} 63+\mathrm{H} 78\end{array}$ \\
\hline BotxNy & Not used & Not used & Not used & Not used \\
\hline
\end{tabular}

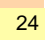


Water sampling

Who filled this form

Telephone (international)

Participant

Participant code \#

Heading line

Arrival date of PS material/mussels

Coordinate $x$ (decimal degrees) \#

Coordinate y (decimal degrees)

Water depth

Deployment depth

Data of deployment.\#

Water Temp on deployment $\left({ }^{\circ} \mathrm{C}\right)$

Air Temp on deployment $\left({ }^{\circ} \mathrm{C}\right)$

SPM or Secci on deployment

Exposed (d)

Data of recovery.\#

Water Temp on recovery $\left({ }^{\circ} \mathrm{C}\right)$

Air Temp on recovery $\left({ }^{\circ} \mathrm{C}\right)$

Salinity on recovery (o/oo)

SPM or Secci on recovery

Decribe fouling in a comment

Duplicate send to REF lab.

Sampler cage number

Sheet holder number

Sheet weight after extraction

Average shell length ( $\mathrm{mm}$ )

Average dry flesh weight

Extractable lipid

hexachlorobenzene

2,2',5-trichlorobipheny

2,4,4-trichlorobipheny

2,2, $3,35^{\prime}$-tetrachlorobipheny

$2,2^{\prime}, 5,5$ '-tetrachlorobiphenyl

2,2',4,5,5-pentachlorobipheny

2,3,3',4,4'-pentachlorobipheny

2,3',4,4,5-pentachlorobipheny

$2,2^{\prime}, 3,4,4^{\prime}, 5^{\prime}$-hexachlorobiphen

$2,2^{\prime}, 4,4^{\prime}, 5,5^{\prime}$-hexachlorobiphenyl

2,2',3,3',4,4',5-heptachlorobiphen

$2,2,3,4,4,5,5$-heptachlorobiphen

$2,2^{\prime}, 3,4^{\prime}, 5,5^{\prime}, 6$-heptachlorobiphen

2,6-Dichorobiphenyl

3,5-Dichorobipheny

2,3,4-trichorobiphenyl

2,4,6-trichorobiphenyl

$2,2,4,6$-tetrachorobiphenyl

3,3, 4,6-tetrachorobiphenyl

2, 2, $4,6,6$ '-pentachorobiphenyl

2,2,', , 6, 6,6,6'-pentachorobiphenyl

2, 2',3,4,4',5,6,6'-octachlorobiphenyl

naphthalene

acenaphthene

acenaph

phenanthrene

anthracene

fluoranthen

pyrene

benzo[a]anthracene

chrysene

benzo[e]pyrene

benzo[a]pyrene

benzo[ghilperylene

indeno[1,2,3-cd]pyrene

Naphtalene-D8

Fluorene-D10

Phenanthrene D10

Fluoranthene-D10

Benz(e)pyrene-D

Benz(e)pyrene-D12
Perylene-D12

Perylene-D12

Type ICES code in righthand cell
Martin M. Larsen

$\frac{\text { mml@dmu.dk }}{4546301259}$

NERI, Denmark

NERI, Denmark

NER05

\begin{tabular}{|c|c|c|c|c|c|c|c|}
\hline & & & Procedural & Sample for & Mussel & Mussel after & $\begin{array}{l}\text { Free diss. } \\
\text { Water } \\
\text { conc }\end{array}$ \\
\hline $\begin{array}{l}\text { Empty06 } \\
\text { DDxArr }\end{array}$ & 28-Sep-06 & Reference & & & & Blue Mussels & \\
\hline XCrd & 62.006933 & & & & & 62.006933 & \\
\hline Ycrd & -6.76748333 & & & & & -6.76748333 & \\
\hline WTRxDepth & 10 & & & & & 10 & \\
\hline ExpxDepth & 1.5 & & & & & 1.5 & \\
\hline
\end{tabular}

ExpxDepth

Empty01

TwtrxStart

TairxStart

SALXStart

Empty02

Days

Days

TwtrxEnd

TairxEnd

SALxEnd

SALXEnd

Fouling

Empty04

DDxRef
Empty05

29-Nov-06

8
7
34.629

34.629
11.5

11.5

$\begin{array}{r}44.0 \\ 12-J a n-07 \\ 7.5 \\ 2 \\ 34.9085 \\ \hline\end{array}$

9.5
Slightly colored

9.5

$\begin{array}{llll}\text { SCxNr } & \text { K9 } & & \\ \text { SHxNr } & \text { H29 } & & \text { K9 } \\ \text { BotxNr } & \text { Not used } \quad \text { Not used } & \text { Not used } & \text { H74 } \\ \text { MA } & & & \text { Not used }\end{array}$

BotXN

MusselN

ShellxL

FleshDry

Exlip

HCB
CB18
CB28

CB28
CB31

CB31

CB44
CB52

CB101

CB105

CB118

$\mathrm{CB} 138$
$\mathrm{CB} 153$

CB153
CB170

CB180

CB187
CB10
CB14
CB21

CB14
CB21
CB30

CB30
CB50
CB78
CB55
CB104

CB55
CB104

CB145

CB204
Nap
Acne

Acnle

Fle

Ant

Ant
Flu

Flu
Pyr

Baa

Chr

BaP

BghiP

ICDP

NAPxD8

PAxD10

FluxD10

FluxD10
ChrxD12

ChrxD12

PexD12

CORXD12

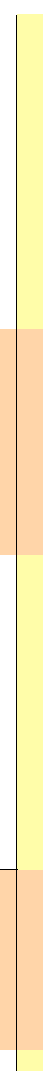

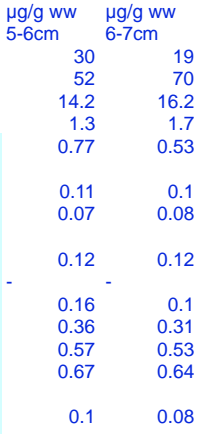

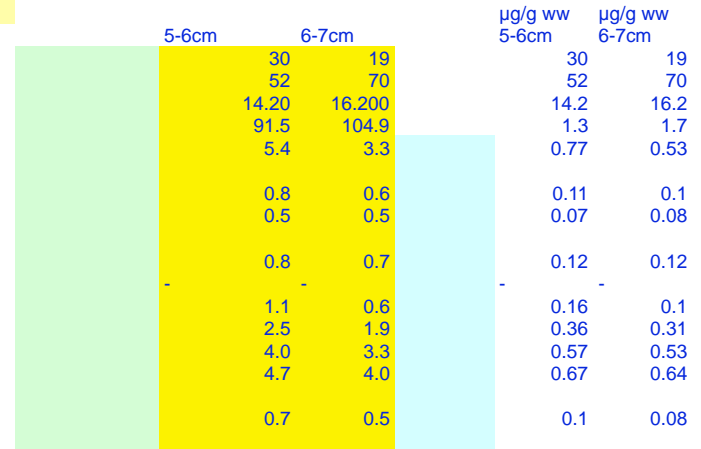


Who filled this form

email

Telephone (international)

Participant

Participant code \#

Station code \#

Heading line

Arrival date of PS material/mussels Coordinate $x$ (decimal degrees) \#

Coordinate y (decimal degrees) \#

Water depth

Deployment depth

Data of deployment.\#

Water Temp on deployment $\left({ }^{\circ} \mathrm{C}\right)$

Air Temp on deployment $\left({ }^{\circ} \mathrm{C}\right)$

Salinity on deployment (o/oo)

SPM or Secci on deployment

Exposed (d)

Data of recovery.\#

Water Temp on recovery $\left({ }^{\circ} \mathrm{C}\right)$

Air Temp on recovery $\left({ }^{\circ} \mathrm{C}\right)$

Salinity on recovery (o/oo)

Salinity on recovery (o/oo)
SPM or Secci on recovery

Decribe fouling in a comment

Duplicate send to REF lab.

Sampler cage numbe

Sheet holder number

Sheet Bottle number

Sheet weight after extraction \#

Number of mussels

Average shell length (mm)

Average dry flesh weight

Extractable lipid

hexachlorobenzene

$2,2,5$-tichlorobiphenyl

2,4,4-trichlorobiphenyl

$2,4,5$-trichlorobiphenyl
$2,2,3,5^{\prime}$-tetrachlorobipheny

$2,2,3,5^{\prime}$-tetrachlorobiphenyl
$2,2,5,5^{\prime}$-tetrachlorobiphenyl

$2,2^{2}, 5,5^{\prime}$ 'tetrachlorobiphenyl
$2,2^{2}, 4,5,5^{\prime}$-pentachlorobiphenyl

2,3,3',4,4'-pentachlorobiphenyl

2,3',4,4',5-pentachlorobiphenyl

2,2',3,4,4',5'-hexachlorobiphenyl

$2,2^{\prime}, 4,4^{\prime}, 5,5^{\prime}$-hexachlorobiphenyl

2,2',3,3',4,4',5-heptachlorobiphenyl

$2,2^{\prime}, 3,4,44^{\prime}, 5,5^{\prime}$-heptachlorobipheny

2,2',3,4',5,5',6-heptac

3,6-Dichorobiphenyl

2,3,4-trichorobiphenyl

2,3,4-trichorobipheny

2,4,6-trichorobiphenyl

$2,2,4,6$-tetrachorobipheny

3,3,4,6-tetrachorobipheny

2,3,3',4-tetrachorobiphenyl

$2,2^{\prime}, 3,4,6,6$ '-pentachorobiphenyl

2,2 ', $3,4,4,4^{\prime}, 5,6,6$ '-octachlorobipheny

naphthalene

acenaphthene

acenaphthylene

fluorene

phenanthrene

anthracene

fluoranthen

pyrene

benzo[a]anthracene

chrysene

benzo[e]pyrene

benzo[e]pyrene

benzo[ghilperylene

indeno[1,2,3-cd]pyrene

Naphtalene-D8

Fluorene-D10

Phenanthrene D10
Fluoranthene-D10

Chrysene-D10

Benz(e)pyrene-D12

Perylene-D12

Coronene-D12

Type ICES code in righthand cell

$\begin{array}{ll}\text { Name } & \text { Martin M. Larsen } \\ \text { Email } & \text { mml@dmu.dk } \\ \text { Tel } & 4546301259 \\ \text { Institute } & \text { NERI, Denmark } \\ \text { PartC } & \text { NERI, Denmark } \\ \text { StatC } & \text { NER06 }\end{array}$

StatC NER06

\begin{tabular}{|c|c|c|c|c|c|c|c|}
\hline Empty06 & Sample & Reference & $\begin{array}{l}\text { Procedural } \\
\text { Blank }\end{array}$ & $\begin{array}{l}\text { Sample for } \\
\text { ref lab }\end{array}$ & $\begin{array}{l}\text { Mussel } \\
\text { Start }\end{array}$ & $\begin{array}{l}\text { Mussel after } \\
\text { or local }\end{array}$ & $\begin{array}{l}\text { Free diss. } \\
\text { Water } \\
\text { conc. }\end{array}$ \\
\hline DDxArr & 28-Sep-06 & & & & & Blue Mussels & \\
\hline XCrd & 62.006933 & & & & & 62.006933 & \\
\hline Ycrd & -6.7709 & & & & & -6.7709 & \\
\hline WTRxDepth & 6 & & & & & 6 & \\
\hline ExpxDepth & 1.5 & & & & & 1.5 & \\
\hline
\end{tabular}

Empty01

29-Nov-06

$\begin{array}{lr}\text { TwtrxStart } & 8 \\ \text { TairxStart } & 7 \\ \text { SALXStart } & 33.55\end{array}$

SPMXStart

Empty02

Days

DDxEnd

TwtrxEnd

TairxEnd

SALXEnd
SPMXEnd

Fouling

Empty04

DDxRef

Empty05

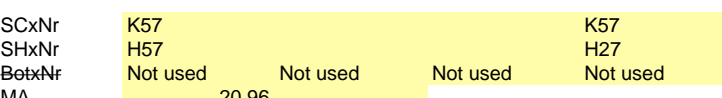

BotxNr Not used Not used Not used Not used

MA

ShellxL

FleshDry

FleshD
Exlip
HCB

$\mathrm{HCB}$
$\mathrm{CB} 18$

CB18
CB28

CB28
CB31

CB44

CB52
CB101

CB105

CB118

CB138

CB153

CB170
CB180

CB187
CB10
CB14

CB14
CB21
CB30

CB30

CB50

CB78
CB55
CB104

CB145

CB204

Nap

Acne

Acnle

Fle

PA

Ant
Flu

Flu

Pyr
Baa

Chr

BeP

Bghip

\begin{tabular}{l} 
Bghip \\
ICDP \\
\hline NAPXD8
\end{tabular}

NAPXD8

FLEXD10

PAxD10

FluxD10

ChrxD12

BePxD12

PexD12

CORXD12

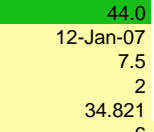

Slightly colored

Slightly colored
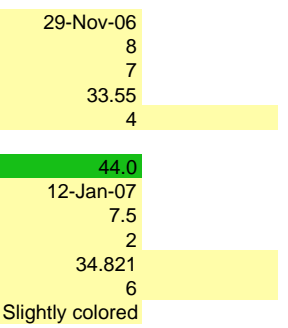
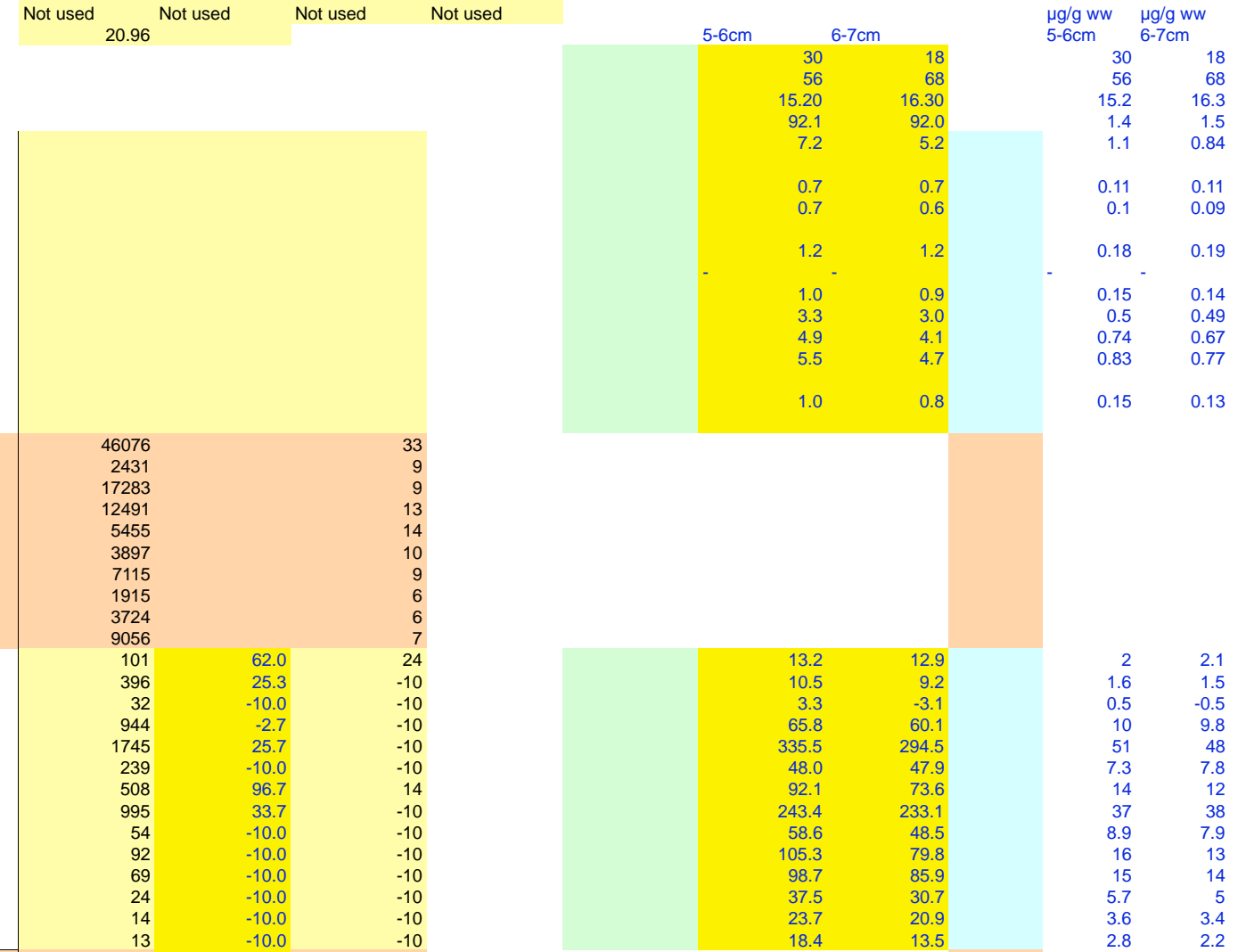


\section{Water sampling}

NER07

Who filled this form

email

Telephone (international)

Participant

Participant code \#

Station code \#

Heading line

Arrival date of PS material/mussels

Coordinate $\mathrm{x}$ (decimal degrees) \#

Coordinate y (decimal degrees) \#

Water depth

Deployment depth

Data of deployment.\#

Water Temp on deployment $\left({ }^{\circ} \mathrm{C}\right)$

Air Temp on deployment $\left({ }^{\circ} \mathrm{C}\right)$

Salinity on deployment (o/oo)

SPM or Secci on deployment

Exposed (d)

Data of recovery.\#

Water Temp on recovery $\left({ }^{\circ} \mathrm{C}\right)$

Air Temp on recovery $\left({ }^{\circ} \mathrm{C}\right)$

Salinity on recovery (o/oo)

SPM or Secci on recovery

Decribe fouling in a comment

Duplicate send to REF lab.

Sampler cage numbe

Sheet holder number

Sheet Bottle number

Sheet weight after extraction \#

Number of mussels

Average shell length ( $\mathrm{mm}$ )

Average dry flesh weight

Extractable lipid

hexachlorobenzene

2,2',5-trichlorobiphenyl

2,4,4'-trichlorobiphenyl

2,4',5-trichlorobiphenyl

2,2',3,5'-tetrachlorobiphenyl

2,2',5,5'-tetrachlorobiphenyl

2,2', 4,5,5'-pentachlorobiphenyl

2,3,3',4,4'-pentachlorobiphenyl

2,3',4,4',5-pentachlorobiphenyl

$2,2^{\prime}, 3,4,4^{\prime}, 5^{\prime}$-hexachlorobiphenyl

2,2',4,4',5,5'-hexachlorobiphenyl

2, 2', 3, 3', 4, 4', 5-heptachlorobiphenyl

$2,2^{\prime}, 3,4,4^{\prime}, 5,5^{\prime}$-heptachlorobiphenyl

2,2',3,4',5,5',6-heptachlorobiphenyl

2,6-Dichorobiphenyl

3,5-Dichorobiphenyl

2,3,4-trichorobiphenyl

2,4,6-trichorobiphenyl

2,2',4,6-tetrachorobipheny

3,3',4,6-tetrachorobiphenyl

2,3,3, 4-tetrachorobipheny

2,2', 4,6,6'-pentachorobiphenyl

2,2',3,4,6,6'-pentachorobiphenyl

$2,2^{\prime}, 3,4,4$ ', $5,6,6^{\prime}$-octachlorobiphenyl

naphthalene

acenaphthene

acenaphthylene

fluorene

phenanthrene

anthracene

fluoranthene

pyrene

benzo[a]anthracene

chrysene

benzo[e]pyrene

benzo[a]pyrene

benzo[ghi]perylene

indeno[1,2,3-cd]pyrene

Naphtalene-D8

Fluorene-D10

Phenanthrene D10

Fluoranthene-D10

Chrysene-D10

Benz(e)pyrene-D12

Perylene-D12

Coronene-D12

DDE (p,p')

$\begin{array}{ll}\text { Name } & \text { Martin M. Larsen } \\ \text { Email } & \frac{\text { mml@dmu.dk }}{4546301259} \\ \text { Tel } & \text { NERI, Denmark } \\ \text { Institute } & \text { NERI, Denmark } \\ \text { PartC } & \text { NERI } \\ \text { StatC } & \text { NER07 }\end{array}$

StatC NER07

-

DDxStart

TairxStart

SALXStart

SPMXStart

Empty02

Days

DDxEnd

TwtrxEnd

TairxEnd

SALXEnd

SPMXEnd

Fouling

Empty04

DDxRef

Empty05

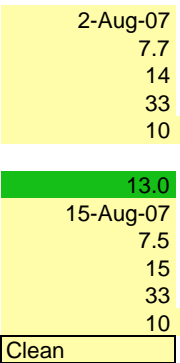

MusselNr

ShellxL

FleshDry

Exlip

HCB

CB18

CB28

CB31

CB44

CB52

CB101

CB105

CB118

CB138

CB153

CB170

CB180

CB187

CB10

CB14

CB21

CB30

CB50
CB78

CB55

CB104

CB145

CB204

Nap

Acne

Acnle

$\mathrm{Fle}$

PA

Flu

Pyr
Baa

Baa

BeP

BaP

Bghip

ICDP

NAPxD8

FLExD10

PAxD10

FluxD10

ChrxD12

BePxD12

PexD12

CORXD12

DDEPP

\begin{tabular}{|c|c|c|c|c|c|c|c|}
\hline Empty06 & Sample & Reference & $\begin{array}{l}\text { Procedural } \\
\text { Blank }\end{array}$ & $\begin{array}{l}\text { Sample for } \\
\text { ref lab }\end{array}$ & $\begin{array}{l}\text { Mussel } \\
\text { Start }\end{array}$ & $\begin{array}{l}\text { Mussel after } \\
\text { or local }\end{array}$ & $\begin{array}{l}\text { Free diss. } \\
\text { Water } \\
\text { conc. }\end{array}$ \\
\hline DDxArr & 28-Sep-06 & & & & & local Mytilus edulis & \\
\hline XCrd & 66.938 & 66 56' $25.3 \mathrm{~N}$ & & & & 66.938 & \\
\hline Ycrd & -52.993 & 53 41' 16.1W & & & & -52.993 & \\
\hline WTRxDepth & 5 & & & & & $0.000 \mathrm{C}$ & on the rocks $r$ \\
\hline ExpxDepth & 0.5 & & & & & 0.000 & \\
\hline
\end{tabular}

local

\begin{tabular}{|c|c|c|c|c|}
\hline $\mathrm{SCxNr}$ & K7 & & & K7 \\
\hline $\mathrm{SH} \times \mathrm{Nr}$ & H86 & & & $\mathrm{H} 46$ \\
\hline BotxNr & Not used & Not used & Not used & Not used \\
\hline
\end{tabular}
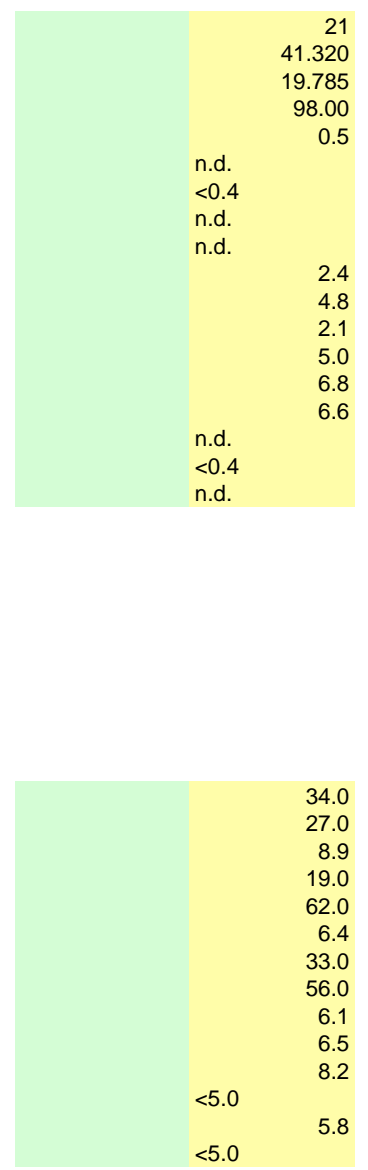


\section{Water sampling}

NER08

Who filled this form

email

Telephone (international)

Participant

Participant code \#

Station code \#

Heading line

Arrival date of PS material/mussels

Coordinate $\mathrm{x}$ (decimal degrees) \#

Coordinate y (decimal degrees) \#

Water depth

Deployment depth

Data of deployment.\#

Water Temp on deployment $\left({ }^{\circ} \mathrm{C}\right)$

Air Temp on deployment $\left({ }^{\circ} \mathrm{C}\right)$

Salinity on deployment (o/oo)

SPM or Secci on deployment

Exposed (d)

Data of recovery.\#

Water Temp on recovery $\left({ }^{\circ} \mathrm{C}\right)$

Air Temp on recovery $\left({ }^{\circ} \mathrm{C}\right)$

Salinity on recovery (o/oo)

SPM or Secci on recovery

Decribe fouling in a comment

Duplicate send to REF lab.

Sampler cage numbe

Sheet holder number

Sheet Bottle number

Sheet weight after extraction \#

Number of mussels

Average shell length ( $\mathrm{mm}$ )

Average dry flesh weight

Extractable lipid

hexachlorobenzene

2,2',5-trichlorobiphenyl

2,4,4'-trichlorobiphenyl

2,4',5-trichlorobiphenyl

2,2',3,5'-tetrachlorobiphenyl

2,2',5,5'-tetrachlorobiphenyl

2,2', 4,5,5'-pentachlorobiphenyl

2,3,3',4,4'-pentachlorobiphenyl

2,3',4,4',5-pentachlorobiphenyl

$2,2^{\prime}, 3,4,4^{\prime}, 5^{\prime}$-hexachlorobiphenyl

$2,2^{\prime}, 4,4$ ',5,5'-hexachlorobiphenyl

2, 2', 3, 3', 4, 4', 5-heptachlorobiphenyl

$2,2^{\prime}, 3,4,4^{\prime}, 5,5^{\prime}$-heptachlorobiphenyl

2,2',3,4',5,5',6-heptachlorobiphenyl

2,6-Dichorobiphenyl

3,5-Dichorobiphenyl

2,3,4-trichorobiphenyl

2,4,6-trichorobiphenyl

2,2',4,6-tetrachorobipheny

3,3',4,6-tetrachorobiphenyl

2,3,3',4-tetrachorobiphenyl

2,2', 4,6,6'-pentachorobiphenyl

2,2',3,4,6,6'-pentachorobiphenyl

$2,2^{\prime}, 3,4,4^{\prime}, 5,6,6^{\prime}$-octachlorobiphenyl

naphthalene

acenaphthene

acenaphthylene

fluorene

phenanthrene

anthracene

fluoranthene

pyrene

benzo[a]anthracene

chrysene

benzo[e]pyrene

benzo[a]pyrene

benzo[ghi]perylene

indeno[1,2,3-cd]pyrene

Naphtalene-D8

Fluorene-D10

Phenanthrene D10

Fluoranthene-D10

Chrysene-D10

Benz(e)pyrene-D12

Perylene-D12

Coronene-D12

Type ICES code in righthand cell

\begin{tabular}{ll} 
Name & Martin M. Larsen \\
Email & mml@dmu.dk \\
Tel & 4546301259 \\
Institute & NERI, Denmark \\
PartC & NERI, Denmark \\
StatC & NER08 \\
\hline
\end{tabular}

ExpxDepth

Empty01

DDxStart

TwtrxStart

TairxStart

SALXStart

Empty02

Days

DDxEnd

TwtrxEnd

TairxEnd

SALXEnd

SPMXEnd

Fouling

Empty04

DDxRef

Empty05

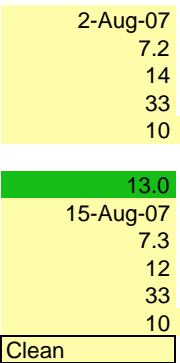

MusselNr

ShellxL

FleshDry

Exlip

HCB

CB18

CB28

CB31

CB44

CB52

CB101

CB105

CB118

CB138

CB153

CB170

CB180

CB187

CB10

CB14

CB21

CB30

CB50
CB78

CB55

CB104

CB145

CB204

Nap

Acne

Acnle

Fle

PA

Flu

Pyr

Baa

BeP

$\mathrm{BaP}$

Bghip

ICDP

NAPxD8

FLEXD10

PAxD10

FluxD10

ChrxD12

BePxD12

PexD12

\begin{tabular}{|c|c|c|c|c|c|c|c|}
\hline Empty06 & Sample & Reference & $\begin{array}{l}\text { Procedural } \\
\text { Blank }\end{array}$ & $\begin{array}{l}\text { Sample for } \\
\text { ref lab }\end{array}$ & $\begin{array}{l}\text { Mussel } \\
\text { Start }\end{array}$ & $\begin{array}{c}\text { Mussel after } \\
\text { or local }\end{array}$ & $\begin{array}{l}\text { Free diss. } \\
\text { Water } \\
\text { conc. }\end{array}$ \\
\hline DDxArr & 28-Sep-06 & & & & & local & \\
\hline XCrd & 66.926 & 6656 ' ON & & & & 66.934 & $66^{\circ} 56^{\prime} 2.6^{\prime \prime} \mathrm{N}$ \\
\hline Ycrd & -53.704 & 5344 ' 50.9W & & & & -53.742 & $53^{\circ} 44^{\prime} 51.7^{\prime \prime W}$ \\
\hline WTRxDepth & 5 & & & & & 0 & Picked at low tide, $3-4 \mathrm{n}$ \\
\hline ExpxDepth & 0.5 & & & & & 0 & \\
\hline
\end{tabular}

local

0

$\begin{array}{lllll}\mathrm{SCXNr} & \mathrm{K} 7 & & & \mathrm{~K} 7 \\ \mathrm{SHxNr} & \mathrm{H} 86 & & & \mathrm{H} 46 \\ \text { BotxNr } & \text { Not used } & \text { Not used } & \text { Not used } & \text { Not used } \\ \text { MA } & & 7.07 & \end{array}$

Clean
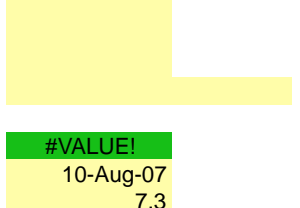

12

10

45.890

18.039

61.00

n.d.

$<0.4$

n.d.

n.d.

$<0.4$

$<0.4$

0.5

0.6

2.8

3.9

n.d.

n.d.

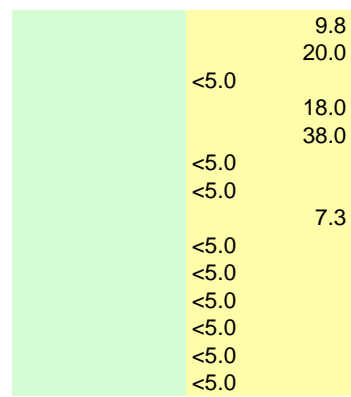


Water sampling

Who filled this form

email

Telephone (international)

Participant code \#

Station code \#

Heading line

Arrival date of PS material/mussels Coordinate $\mathrm{x}$ (decimal degrees) \#

Coordinate y (decimal degrees) \#

Water depth

Deployment depth

Data of deployment.\#

Water Temp on deployment $\left({ }^{\circ} \mathrm{C}\right)$

Air Temp on deployment $\left({ }^{\circ} \mathrm{C}\right)$

Salinity on deployment (o/oo)

SPM or Secci on deployment

Exposed (d)

Data of recovery.\#

Water Temp on recovery $\left({ }^{\circ} \mathrm{C}\right)$

Air Temp on recovery $\left({ }^{\circ} \mathrm{C}\right)$

Salinity on recovery (o/oo)

SPM or Secci on recovery

Decribe fouling in a comment

Duplicate send to REF lab.

Sampler cage number

Sheet holder number

Sheet Bottle number

Sheet weight after extraction \#

Number of mussels

Average shell length $(\mathrm{mm})$

Average dry flesh weigh

Extractable lipid

hexachlorobenzene

2,2',5-trichlorobiphenyl

2,4,4'-trichlorobiphenyl

2,4, 5 -trichlorobiphenyl

$2,2^{\prime}, 3,5^{\prime}$-tetrachlorobiphenyl
$2,2,5,5^{\prime}$-tetrachlorobiphenyl

2,2',5,5'-tetrachlorobiphenyl

2,2',4,5,5'-pentachlorobipheny

2,3', 4, 4', 5-pentachlorobipheny

$2,2^{\prime}, 3,4,4^{\prime}, 5^{\prime}$-hexachlorobiphenyl

$2,2^{\prime}, 4,4^{\prime}, 5,5^{\prime}$-hexachlorobiphenyl

$2,2^{\prime}, 3,3^{\prime}, 4,4^{\prime}, 5$-heptachlorobiphenyl

$2,2^{\prime}, 3,4,4^{\prime}, 5,5^{\prime}$-heptachlorobiphenyl

2,2',3,4',5,5',6-heptachlorobiphenyl

2,6-Dichorobiphenyl

3,5-Dichorobiphenyl

2,3,4-trichorobiphenyl

2,4,6-trichorobiphenyl

2,2', 4,6-tetrachorobipheny

3,3',4,6-tetrachorobiphenyl

2,3,3',4-tetrachorobiphenyl

2, 2', 4,6,6'-pentachorobiphenyl

$2,2^{\prime}, 3,4,6,6$ '-pentachorobiphenyl

$2,2^{\prime}, 3,4,4^{\prime}, 5,6,6$ '-octachlorobipheny

naphthalene

acenaphthene

acenaphthylene

fluorene

phenanthrene

anthracene

fluoranthen

pyrene

pyrene

chrysene

benzo[e]pyrene

benzo[a]pyrene

benzo|ghi|perylene

indeno[1,2,3-cd]pyrene

Naphtalene-D8

Fluorene-D10

Phenanthrene D10

Fluoranthene-D10

Chrysene-D10

Benz(e)pyrene-D12

Perylene-D12

Coronene-D12

Type ICES code in righthand cell

Type ICES code in righthand cell

Empty

SCXN

SHXNr
BotxNr

BotxNr

Exlip

HCB
CB18

$\mathrm{CB} 18$
$\mathrm{CB} 28$

CB31

CB44

CB52

CB101

CB105

CB138

CB138

CB153

CB170
CB180

CB187
CB10

CB10
CB14
CB21
CB30

CB50

CB78

CB55

CB104

CB145

CB20
Nap

Nap

Acne
Acnle

Acnle
Fle

PA

Ant
Flu
Pyr

ICDP

$"$

\section{NIV01}

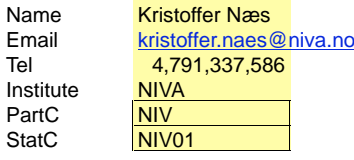

\begin{tabular}{|c|c|c|c|c|c|c|c|}
\hline Empty06 & Sample & Reference & $\begin{array}{l}\text { Procedural } \\
\text { Blank }\end{array}$ & $\begin{array}{l}\text { Sample for } \\
\text { ref lab }\end{array}$ & $\begin{array}{l}\text { Mussel } \\
\text { Start }\end{array}$ & $\begin{array}{l}\text { Mussel after } \\
\text { or local }\end{array}$ & $\begin{array}{l}\text { Free diss. } \\
\text { Water } \\
\text { conc. }\end{array}$ \\
\hline \multicolumn{8}{|l|}{ DDxArr } \\
\hline XCrd & 13.122 & & & & & 1307.317 & \\
\hline Ycrd & 65.895 & & & & & 6253.712 & \\
\hline
\end{tabular}

WTRxDepth

ExpxDepth

Empty01

DDxStart

TwtrxStart

TairxStart

SALXStart

SPMXSta

Days

DDxEnd
TwtrxEnd

TairxEnd

SALXEnd

SPMXEnd

Fouling

Empty04

DDxRef

Empty05

MusselNr

ShellxL

FleshDry

CB180
CB187

1.5

30

1.5

1-Nov-06

10
-13

$<0.10 \quad \mathrm{mg} / \mathrm{l}$

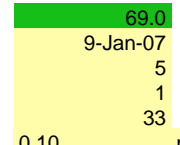

$0.10 \quad \mathrm{~m}$

$\mathrm{mg} / \mathrm{l}$

Slightly colored

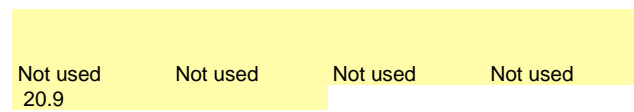

20.9

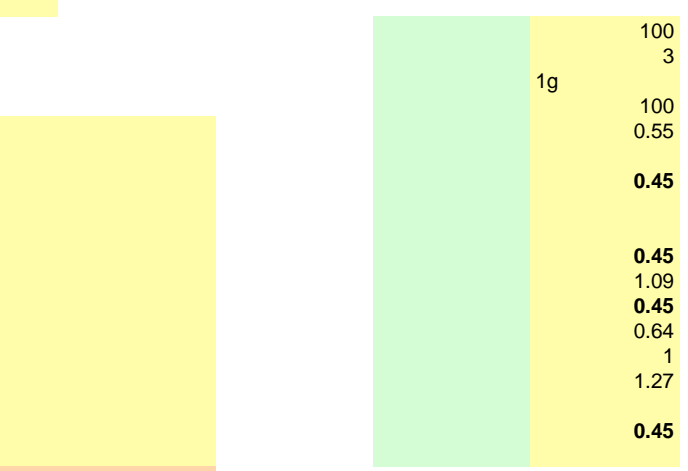

45

.45

.45

0.45

607

Pyr $\quad 346$

Baa $\quad 47<10$

BeP $\quad 77<10$

BaP $\quad 22<10$

Bghip

NAPXD8

FLEXD10

PAxD10

FluxD10

ChrxD12

BePxD12

CORxD12 
Water sampling

Fcode

Who filled this form

email

Telephone (international)

Participant code \#

Station code \#

Heading line

Arrival date of PS material/mussels Coordinate $x$ (decimal degrees) \#

Coordinate y (decimal degrees) \#

Water depth

Deployment depth

Data of deployment.\#

Water Temp on deployment $\left({ }^{\circ} \mathrm{C}\right)$

Air Temp on deployment $\left({ }^{\circ} \mathrm{C}\right)$

Salinity on deployment (o/oo)

SPM or Secci on deployment

Exposed (d)

Data of recovery.\#

Water Temp on recovery $\left({ }^{\circ} \mathrm{C}\right.$

Air Temp on recovery $\left({ }^{\circ} \mathrm{C}\right)$

Salinity on recovery (o/oo)

SPM or Secci on recovery

Decribe fouling in a comment

Duplicate send to REF lab.

Sampler cage number

Sheet holder number

Sheet Bottle number

Sheet weight after extraction \#

Number of mussels

Average shell length $(\mathrm{mm})$

Average dry flesh weight

Extractable lipid

hexachlorobenzene

2,2', 5-trichlorobiphenyl

2,4,4'-trichlorobiphenyl

2,4,5-trichlorobiphenyl

$2,2^{\prime}, 3,5^{\prime}$-tetrachlorobiphenyl
$2,2,5,5^{\prime}$-tetrachlorobiphenyl

2,2',5,5'-tetrachlorobiphenyl

2,2',4,5,5'-pentachlorobipheny

2,3',4,4, 5-pentachlorobiphenyl

$2,2^{\prime}, 3,4,4^{\prime}, 5^{\prime}$-hexachlorobiphenyl

$2,2^{\prime}, 4,4^{\prime}, 5,5^{\prime}$-hexachlorobiphenyl

$2,2^{\prime}, 3,3^{\prime}, 4,4^{\prime}, 5$-heptachlorobiphenyl

$2,2^{\prime}, 3,4,4^{\prime}, 5,5^{\prime}$-heptachlorobiphenyl

2,2',3,4',5,5',6-heptachlorobiphenyl

2,6-Dichorobiphenyl

3,5-Dichorobiphenyl

2,3,4-trichorobiphenyl

2,4,6-trichorobiphenyl

2,2',4,6-tetrachorobipheny

3,3',4,6-tetrachorobiphenyl

2,3,3',4-tetrachorobiphenyl

2,2', 4,6,6'-pentachorobiphenyl

$2,2^{\prime}, 3,4,6,6$ '-pentachorobiphenyl

$2,2^{\prime}, 3,4,4^{\prime}, 5,6,6$ '-octachlorobiphenyl

naphthalene

acenaphthene

acenaphthylene

fluorene

phenanthrene

anthracene

fluoranthen

pyrene

pyrene

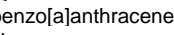

chrysen

benzo[e]pyrene

benzo[a]pyrene

benzo[ghi|perylene

indeno[1,2,3-cd]pyrene

Naphtalene-D8

Fluorene-D10

Phenanthrene D10

Fluoranthene-D10

Chrysene-D10

Benz(e)pyrene-D12

Perylene-D12

Coronene-D12

Type ICES code in righthand cell

Days

SCXN

MA

Exlip

Exlip

HCB
CB18

$\mathrm{CB} 18$
$\mathrm{CB} 28$

CB31

CB44

CB52

CB101

CB105

CB138

CB138

CB153

CB170

CB187

CB10
CB14

CB2

CB21
CB30
CB50

CB50

CB78

CB55

CB104

CB145
CB204
Nap

Nap

Acne
Acnle

Acnle

PA
Ant
Flu

Ant
Flu
Pyr

Baa

Chr
BeP

$\mathrm{BeP}$
$\mathrm{BaP}$

Bghip

ICDP

\section{NIV02}

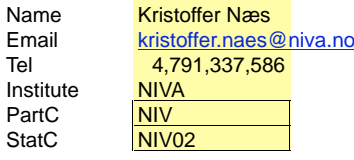

\begin{tabular}{|c|c|c|c|c|c|c|c|}
\hline Empty06 & Sample & Reference & $\begin{array}{l}\text { Procedural } \\
\text { Blank }\end{array}$ & $\begin{array}{l}\text { Sample for } \\
\text { ref lab }\end{array}$ & $\begin{array}{l}\text { Mussel } \\
\text { Start }\end{array}$ & $\begin{array}{c}\text { Mussel after } \\
\text { or local }\end{array}$ & $\begin{array}{l}\text { Free diss. } \\
\text { Water } \\
\text { conc. }\end{array}$ \\
\hline DDxArr & & & & & & & \\
\hline XCrd & 007.986533 & & & & & & \\
\hline Ycrd & 58.112000 & & & & & & \\
\hline WTRxDepth & & & & & & 18 & \\
\hline ExpxDepth & & & & & & 1.5 & \\
\hline
\end{tabular}

Empty01

DDxStart

TairxStart

SALXStart

SALXStart

Empty02

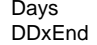

TwtrxEnd

TairxEnd

SALXEnd

SPMXEnd

Fouling

Empty04

DDxRef

Empty05

$\mathrm{SH} \times \mathrm{Nr}$
BotxNr

8-Nov-06

8-Nov-06

12
15

$0.90 \quad \mathrm{mg} / \mathrm{l}$

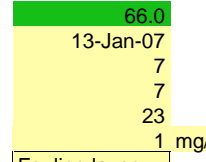

1

g/l

13-Jan-07

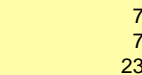

Fouling layer

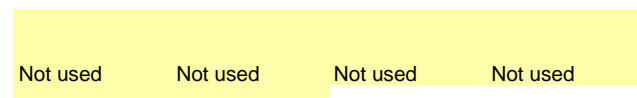

ShellxL

FleshDry

NAPxD8

FLEXD10

PAxD10

FluxD10

ChrxD12

BePxD12

PexD12

CORXD12

Not used Not used Not used Not used

$4 \mathrm{~g} \%$

100.00

4.75

0.75

3.17

5.42

1.25

3.92

0.75

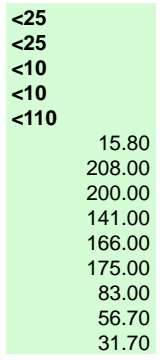

$443<10$

$414<10$
$406<10$

$506<10$

$516<10$ ree diss. 
Water sampling

Who filled this form

email

Telephone (international)

Participant code \#

Station code \#

Heading line

Arrival date of PS material/mussels

Coordinate $\mathrm{x}$ (decimal degrees) \#

Coordinate y (decimal degrees) \#

Water depth

Deployment depth

Data of deployment.\#

Water Temp on deployment $\left({ }^{\circ} \mathrm{C}\right)$

Air Temp on deployment $\left({ }^{\circ} \mathrm{C}\right)$

Salinity on deployment (o/oo)

SPM or Secci on deployment

Exposed (d)

Data of recovery.\#

Water Temp on recovery $\left({ }^{\circ} \mathrm{C}\right)$

Air Temp on recovery $\left({ }^{\circ} \mathrm{C}\right)$

Salinity on recovery (o/oo)

SPM or Secci on recovery

Decribe fouling in a comment

Duplicate send to REF lab.

Sampler cage number

Sheet holder numbe

Sheet Bottle number

Sheet weight after extraction \#

Number of mussels

Average shell length ( $\mathrm{mm}$ )

Average dry flesh weight

Extractable lipid

hexachlorobenzene

2,2',5-trichlorobiphenyl

2,4,4'-trichlorobiphenyl

2,4',5-trichlorobiphenyl

2,2',3,5'-tetrachlorobiphenyl

$2,2,5,5^{\prime}$-tetrachlorobiphenyl

2,2',4,5,5'-pentachlorobiphenyl

2,3,3',4,4'-pentachlorobiphenyl

2,3',4,4',5-pentachlorobiphenyl

$2,2^{\prime}, 3,4,4^{\prime}, 5^{\prime}$-hexachlorobiphenyl

$2,2^{\prime}, 4,4^{\prime}, 5,5^{\prime}$-hexachlorobiphenyl

$2,2^{\prime}, 3,3,3^{\prime}, 4,4^{\prime}, 5$-heptachlorobiphenyl

$2,2^{\prime}, 3,4,4^{\prime}, 5,5^{\prime}$-heptachlorobiphenyl

$2,2^{\prime}, 3,4^{\prime}, 5,5^{\prime}, 6$-heptachlorobiphenyl

2,6-Dichorobiphenyl

3,5-Dichorobiphenyl

2,3,4-trichorobipheny

2,4,6-trichorobipheny

2,2',4,6-tetrachorobipheny

3,3',4,6-tetrachorobipheny

2,3,3', 4-tetrachorobiphenyl

2,2',4,6,6'-pentachorobiphenyl

2,2',3,4,6,6'-pentachorobiphenyl

2,2 ',3,4,4',5,6,6'-octachlorobiphenyl

naphthalene

acenaphthene

acenaphthylene

fluorene

phenanthrene

anthracene

fluoranthene

fluoran

benzo[a]anthracene

chrysene

benzo[e]pyrene

benzo[a]pyrene

benzo[ghi]perylene

indeno[1,2,3-cd]pyrene

Naphtalene-D8

Phenanthrene D10

Fluoranthene-D10

Chrysene-D10

Benz(e)pyrene-D12

Perylene-D12

Coronene-D12

Type ICES code in righthand cell

scent

SHXNr
BotXNr

MA

Exlip

HCB
CB18

CB18
CB28

CB31

CB44

CB101

CB105

CB118

CB138

CB153

CB18

CB14

CB21

CB50

CB78

CB55

CB104

Nap

Bghip

CDP

BePxD12
NIV03

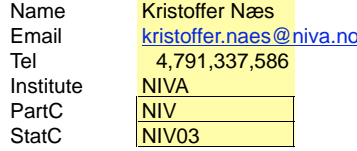

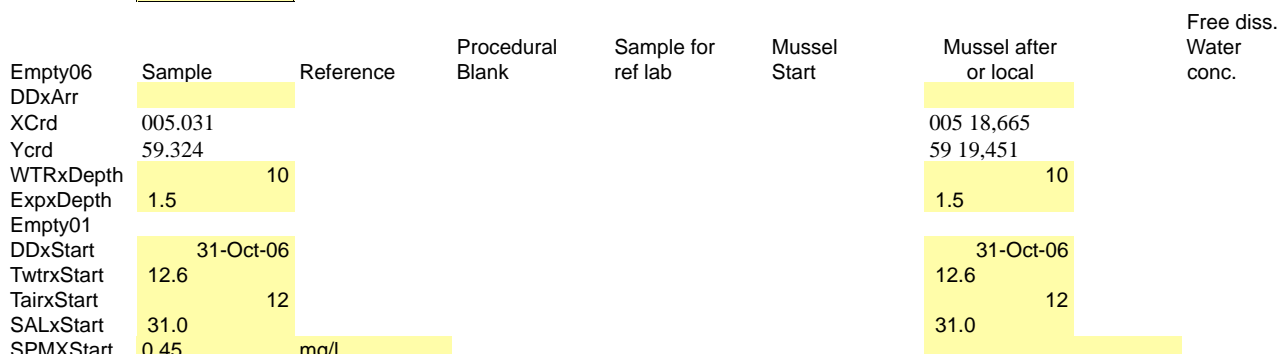$$
\text { 15-Dec-06 }
$$$$
8.57
$$

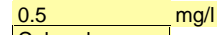

SPMXEnd

Fouling

Empty04

DDxRef
Empty05

MusselNr

ShellxL

FleshDry

CB170
CB180
CB187

CB145
CB204

Colored

$\mathrm{mg} / \mathrm{l}$

5-Dec-06
Not used Not used Not used Not used

$3 g$

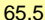

65.5

0.45

0.45

2.55

1.82

5

0.64

\begin{tabular}{rrrr} 
& 2793 & 2304 & 6 \\
Nap & 8921 & 6183 & 7 \\
\hline
\end{tabular}

\begin{tabular}{l|rrr} 
& & 8921 & 6183 \\
Acne & & 232 & 58 \\
Acne & s15383 & & $23<10$
\end{tabular}

\begin{tabular}{rrr} 
Acnle & $188<10$ & $23<10$ \\
\hline & $3218<10$ & $<10$
\end{tabular}

\begin{tabular}{r|rr}
$\mathrm{Fle}$ & $3218<10$ & $<10$
\end{tabular}

\begin{tabular}{l|lll} 
PA 20361,72 & & $22<10$
\end{tabular}

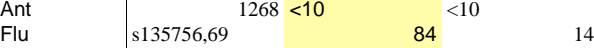

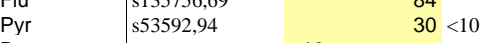

Baa $\quad$ s13064,33 $<10$

\begin{tabular}{l|lr} 
Chr & s10701,44 & $<10$ \\
BeP & & $3729<10$
\end{tabular}

\begin{tabular}{l|l} 
BeP & $3729<10$ \\
BaP & $1676<10$
\end{tabular}

$<10$

$442<10$

$419<10$

$419<10$

$404<10$

$403<10$

$516<10$
$328<10$

$\begin{array}{lll}\text { FluxD10 } & 142 & 404<10 \\ \text { ChrxD12 } & 299 & 403<10 \\ \text { BePxD12 } & 454 & 516<10\end{array}$

CORXD12

454
141

$328<10$
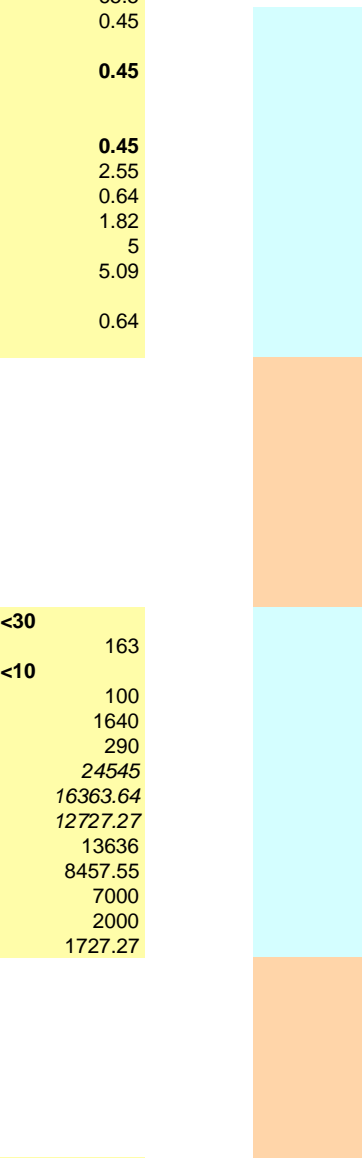
Who filled this form

email

Telephone (international)

Participant

Participant code \#

Station code \#

Heading line

Arrival date of PS material

Coordinate $x$ (decimal degrees) \#

Coordinate y (decimal degrees)\#

Water depth

Sampling depth

Decribe sediment

Condition of sediment

Bottle number \#

Bottle weight before extraction

Date of exposure to sediment \#

Dry weight of exposed sediment \#

Dry weight percentage in sediment

Approx Temperature of exposure $\left({ }^{\circ} \mathrm{C}\right)$

End date of exposure.\#

Exposed (d)

Bottle weight after extraction \#

Comment

Flim damaged? In \% surface \#

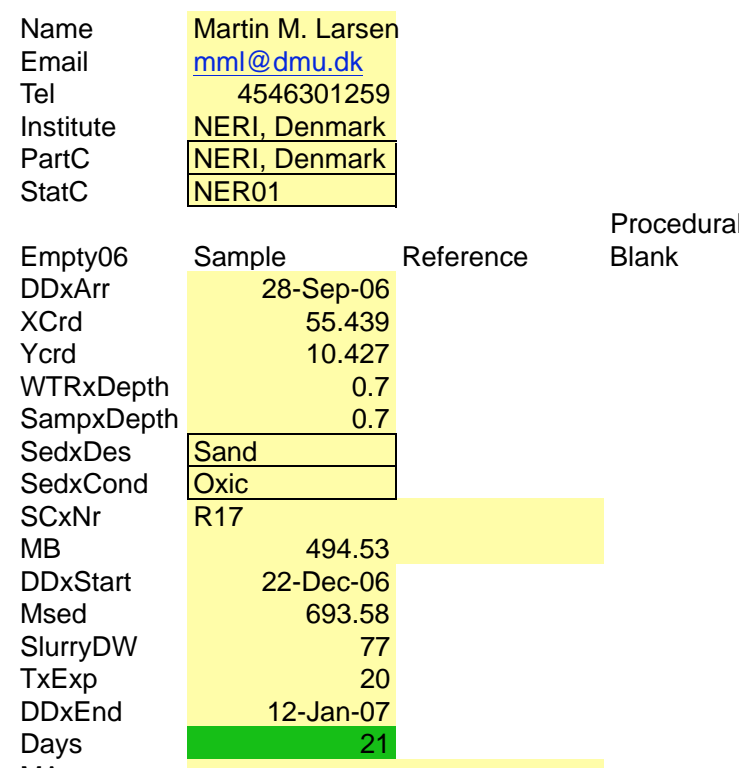

Sample for ref lab Total sediment Pore water
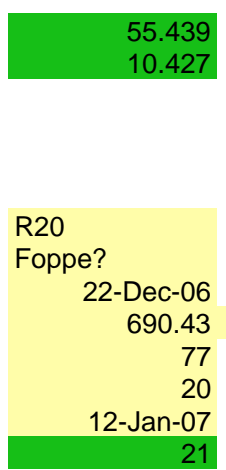

PAHanalysis by NIVA - low PAH's in sediment evaporated during preconcentration. Unable to qua $50 \%$ organic carbon

Dry weight \%

hexachlorobenzene

2,2',5-trichlorobiphenyl

$2,4,4^{\prime}$-trichlorobiphenyl

2,4',5-trichlorobiphenyl

2,2',3,5'-tetrachlorobiphenyl

2,2',5,5'-tetrachlorobiphenyl

2,2',4,5,5'-pentachlorobiphenyl

2,3,3',4,4'-pentachlorobiphenyl

2,3',4,4',5-pentachlorobiphenyl

2,2',3,4,4',5'-hexachlorobiphenyl

2,2 ', 4,4',5,5'-hexachlorobiphenyl

2,2',3,3',4,4',5-heptachlorobiphenyl

2,2',3,4,4',5,5'-heptachlorobiphenyl

2,2',3,4',5,5',6-heptachlorobiphenyl

2,6-Dichorobiphenyl

3,5-Dichorobiphenyl

2,3,4-trichorobiphenyl

2,4,6-trichorobiphenyl

2,2',4,6-tetrachorobiphenyl

3,3',4,6-tetrachorobiphenyl

2,3,3',4-tetrachorobiphenyl

2,2',4,6,6'-pentachorobiphenyl

2,2',3,4,6,6'-pentachorobiphenyl

2,2',3,4,4',5,6,6'-octachlorobiphenyl

naphthalene

acenaphthene

acenaphthylene

fluorene

phenanthrene

anthracene

fluoranthene

pyrene

benzo[a]anthracene

chrysene

benzo[e]pyrene

benzo[a]pyrene

benzo[ghi]perylene

indeno[1,2,3-cd]pyrene

Naphtalene-D8

Fluorene-D10

Phenanthrene D10

Fluoranthene-D10

Chrysene-D10

Benz(e)pyrene-D12

Perylene-D12

Coronene-D12
CORG

DRYWT

HCB

CB18

CB28

CB31

CB44

CB52

CB101

CB105

CB118

CB138

CB153

CB170

CB180

CB187

CB10

CB14

CB21

CB30

CB50

CB78

CB55

CB104

CB145

CB204

$\begin{array}{lrr}\text { Nap } & 23 & -10\end{array}$

$\begin{array}{lll}\text { Acne } & -10 & -10\end{array}$

$\begin{array}{llr}\text { Acnle } & 19 & -10\end{array}$

Fle $\quad 13 \quad-10$

$\begin{array}{lll}\text { PA } & 23 & -10\end{array}$

Ant $\quad 19 \quad-10$

$\begin{array}{lll}\text { Flu } & 51 & 11\end{array}$

$\begin{array}{lll}\text { Pyr } & 36 & 11\end{array}$

Baa $\quad-10 \quad-10$

$\begin{array}{lll}\text { Chr } & 16 & -10\end{array}$

$\begin{array}{lll}\mathrm{BeP} & 16 & -11\end{array}$

$\begin{array}{lll}\text { BaP } & 11 & -12\end{array}$

\begin{tabular}{lll} 
BghiP & 14 & -14 \\
\hline
\end{tabular}

$-13$

NAPXD8 $\quad 34 \quad-10$

FLEXD10 $\quad 78 \quad-10$

PAxD10 $\quad 50 \quad-10$

FluxD10

ChrxD12

BePxD12

PexD12

CORxD12 


\section{Sediment results of Pas Field code}

Who filled this form

email

Telephone (international)

Participant

Participant code \#

Station code \#

Heading line

Arrival date of PS material

Coordinate $x$ (decimal degrees) \#

Coordinate y (decimal degrees)\#

Water depth

Sampling depth

Decribe sediment

Condition of sediment

Bottle number \#

Bottle weight before extraction

Date of exposure to sediment \#

Dry weight of exposed sediment \#

Dry weight percentage in sediment

Approx Temperature of exposure $\left({ }^{\circ} \mathrm{C}\right)$

End date of exposure.\#

Exposed (d)

Bottle weight after extraction \#

Comment

Flim damaged? In \% surface \#

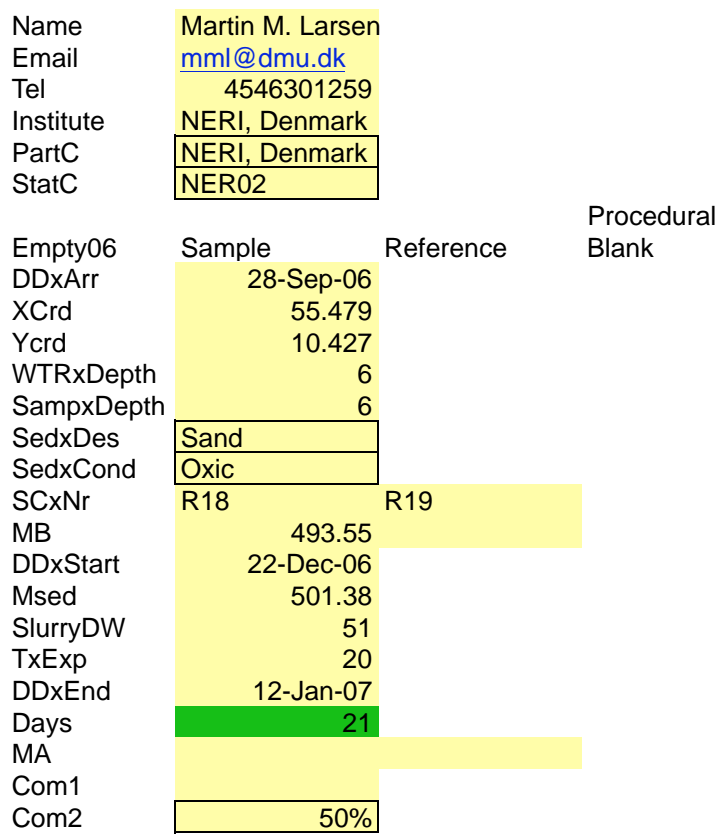

Sample for ref lab

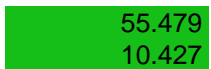

R19

Foppe?

22-Dec-06

501.15

51

20
Total sediment Pore water organic carbon

Dry weight \%

hexachlorobenzene

2,2',5-trichlorobiphenyl

2,4,4'-trichlorobiphenyl

2,4',5-trichlorobiphenyl

2,2',3,5'-tetrachlorobiphenyl

2,2',5,5'-tetrachlorobiphenyl

2,2', 4,5,5'-pentachlorobiphenyl

2,3,3',4,4'-pentachlorobiphenyl

2,3',4,4',5-pentachlorobiphenyl

2,2',3,4,4',5'-hexachlorobiphenyl

2,2',4,4',5,5'-hexachlorobiphenyl

2,2',3,3',4,4',5-heptachlorobiphenyl

2,2',3,4,4',5,5'-heptachlorobiphenyl

2,2',3,4',5,5',6-heptachlorobiphenyl

2,6-Dichorobiphenyl

3,5-Dichorobiphenyl

2,3,4-trichorobiphenyl

2,4,6-trichorobiphenyl

2,2',4,6-tetrachorobiphenyl

3,3',4,6-tetrachorobiphenyl

2,3,3',4-tetrachorobiphenyl

2,2', 4,6,6'-pentachorobipheny

2,2',3,4,6,6'-pentachorobiphenyl

2,2',3,4,4',5,6,6'-octachlorobiphenyl

naphthalene

acenaphthene

acenaphthylene

fluorene

phenanthrene

anthracene

fluoranthene

pyrene

benzo[a]anthracene

chrysene

benzo[e]pyrene

benzo[a]pyrene

benzo[ghi]perylene

indeno[1,2,3-cd]pyrene

Naphtalene-D8

Fluorene-D10

Phenanthrene D10

Fluoranthene-D10

Chrysene-D10

Benz(e)pyrene-D12

Perylene-D12

Coronene-D12

Type ICES code in righthand cell

Type ICES code in righthand cell

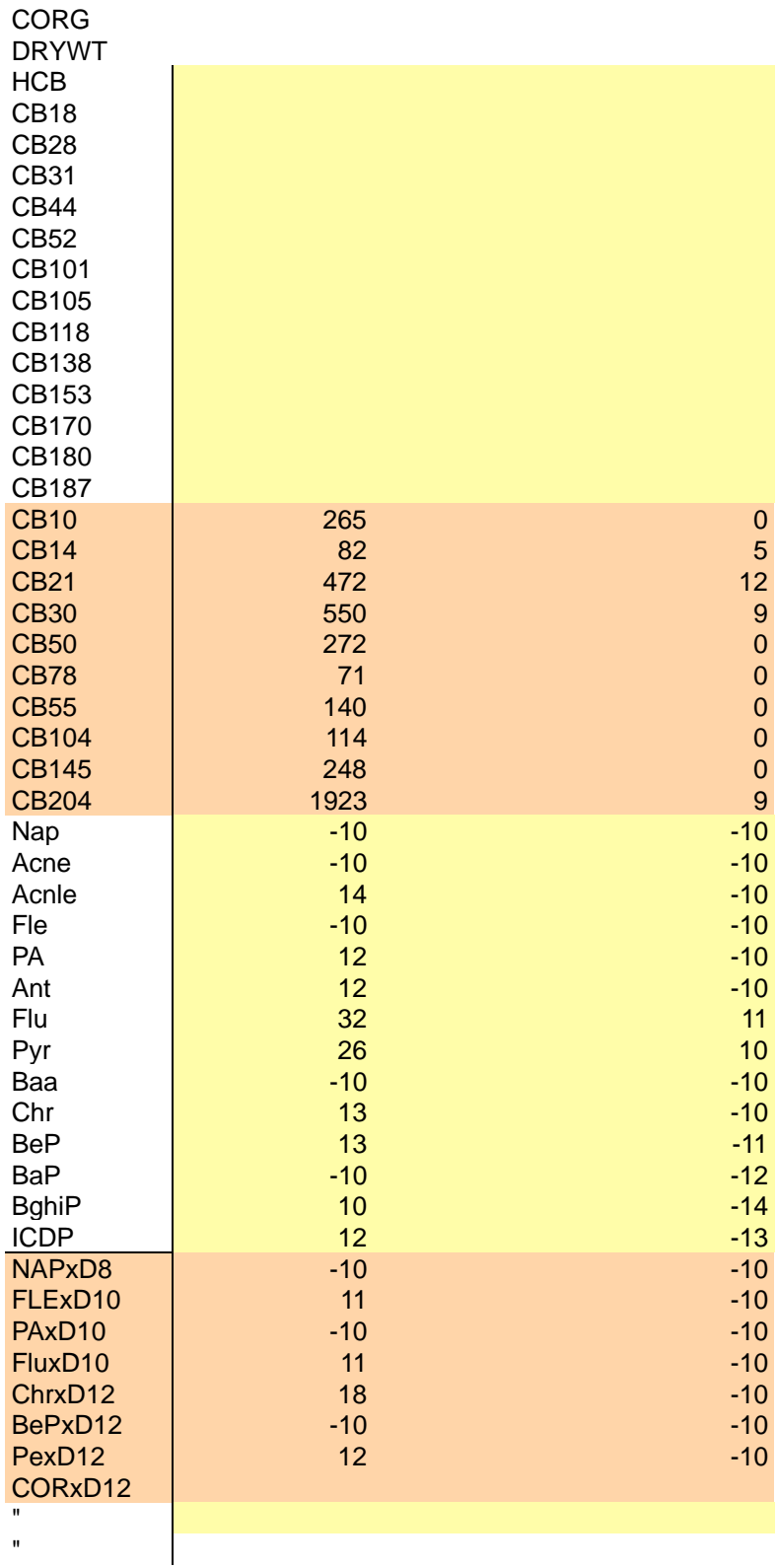

51 
Who filled this form

email

Telephone (international)

Participant

Participant code \#

Station code \#

\section{Heading line}

Arrival date of PS material

Coordinate $x$ (decimal degrees) \#

Coordinate y (decimal degrees)\#

Water depth

Sampling depth

Decribe sediment

Condition of sediment

Bottle number \#

Bottle weight before extraction

Date of exposure to sediment \#

Dry weight of exposed sediment \#

Dry weight percentage in sediment

Approx Temperature of exposure $\left({ }^{\circ} \mathrm{C}\right)$

End date of exposure.\#

Exposed (d)

Bottle weight after extraction \#

Comment

Flim damaged? In \% surface \#

\begin{tabular}{|c|c|c|c|}
\hline Name & Martin M. Larsen & & \\
\hline Email & mml@dmu.dk & & \\
\hline Tel & 4546301259 & & \\
\hline Institute & NERI, Denmark & & \\
\hline PartC & NERI, Denmark & & \\
\hline StatC & NER03 & & \\
\hline Empty06 & Sample & Reference & $\begin{array}{l}\text { Procedural } \\
\text { Blank }\end{array}$ \\
\hline DDXArr & 28-Sep-06 & & \\
\hline XCrd & 58.8667 & & \\
\hline Ycrd & 11.1667 & & \\
\hline WTRxDepth & & & \\
\hline SampxDepth & & & \\
\hline SedxDes & Sand & & \\
\hline SedxCond & Oxic & & \\
\hline $\mathrm{SCxNr}$ & R14 & & \\
\hline $\mathrm{MB}$ & 492.89 & & \\
\hline DDxStart & 26-Mar-07 & & \\
\hline Msed & 179.53 & & \\
\hline SlurryDW & 28 & & \\
\hline TxExp & 20 & & \\
\hline DDxEnd & 16-Apr-07 & & \\
\hline Days & 21 & & \\
\hline
\end{tabular}

Sample for ref lab

Total sediment Pore water
$\mathrm{R} 13$

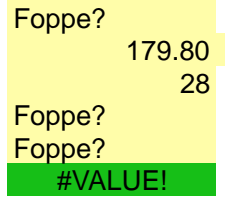

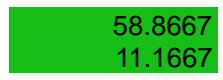

.

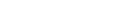

Com 1

Com2

PAHanalysis by NIVA - low PAH's in sediment evaporated during preconcentration $50 \%$

organic carbon

Dry weight \%

hexachlorobenzene

2,2',5-trichlorobiphenyl

$2,4,4^{\prime}$-trichlorobiphenyl

2,4',5-trichlorobiphenyl

2,2',3,5'-tetrachlorobiphenyl

2,2',5,5'-tetrachlorobiphenyl

2,2',4,5,5'-pentachlorobiphenyl

2,3,3',4,4'-pentachlorobiphenyl

2,3',4,4',5-pentachlorobiphenyl

2,2',3,4,4',5'-hexachlorobiphenyl

$2,2^{\prime}, 4,4^{\prime}, 5,5^{\prime}$-hexachlorobiphenyl

2,2',3,3',4,4',5-heptachlorobiphenyl

2,2',3,4,4',5,5'-heptachlorobiphenyl

2,2',3,4',5,5',6-heptachlorobiphenyl

2,6-Dichorobiphenyl

3,5-Dichorobiphenyl

2,3,4-trichorobiphenyl

2,4,6-trichorobiphenyl

2,2',4,6-tetrachorobiphenyl

3,3',4,6-tetrachorobiphenyl

2,3,3',4-tetrachorobiphenyl

2,2',4,6,6'-pentachorobiphenyl

2,2',3,4,6,6'-pentachorobiphenyl

2,2',3,4,4',5,6,6'-octachlorobiphenyl

naphthalene

acenaphthene

acenaphthylene

fluorene

phenanthrene

anthracene

fluoranthene

pyrene

benzo[a]anthracene

chrysene

benzo[e]pyrene

benzo[a]pyrene

benzo[ghi]perylene

indeno[1,2,3-cd]pyrene

Naphtalene-D8

Fluorene-D10

Phenanthrene D10

Fluoranthene-D10

Chrysene-D10

Benz(e)pyrene-D12

Perylene-D12

Coronene-D12

CORG

DRYWT

HCB

CB18

CB28

CB31

CB44

CB52

CB101

CB105

CB118

CB138

CB153

CB170

CB180

CB187

\begin{tabular}{l|ll}
$\mathrm{CB} 10$ & 778 & 0
\end{tabular}

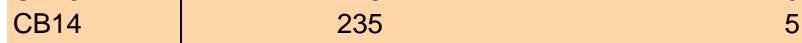

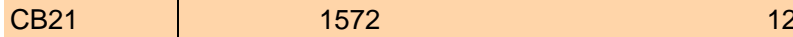

$\begin{array}{rrr}\mathrm{CB} 30 & 1665 & 9\end{array}$

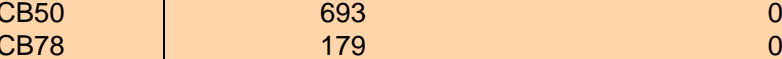

CB55

CB104

CB145

CB204 1985

420

247

247
444

Nap

Acne

Acnle

Fle

PA

Ant

Flu

Pyr

Baa

Chr

BeP

$\mathrm{BaP}$

BghiP

ICDP

$-10$ 
Who filled this form

email

Telephone (international)

Participant

Participant code \#

Station code \#

Heading line

Arrival date of PS materia

Coordinate $x$ (decimal degrees)

Coordinate y (decimal degrees)\#

Water depth

Sampling depth

Decribe sediment

Condition of sedim
Bottle number \#

Bottle number \#

Bottle weight before extraction

Date of exposure to sediment \#

Dry weight of exposed sediment \#

Dry weight percentage in sediment

Approx Temperature of exposure $\left({ }^{\circ} \mathrm{C}\right)$

End date of exposure.\#

Exposed (d)

Bottle weight after extraction \#

Comment

Flim damaged? In \% surface \#

organic carbon

Dry weight $\%$

hexachlorobenzene

2,2',5-trichlorobiphenyl

2,4,4'-trichlorobiphenyl

2,4',5-trichlorobiphenyl

2,2',3,5'-tetrachlorobiphenyl

2,2,5,5'-tetrachlorobiphenyl

2,3,3',4,4'-pentachlorobiphenyl

2,3',4,4',5-pentachlorobiphenyl

$2,2^{\prime}, 3,4,4^{\prime}, 5^{\prime}$-hexachlorobiphenyl

2,2',4,4',5,5'-hexachlorobiphenyl

$2,2,4,4,5,5$ '-hexachlorobiphenyl
$2,2^{\prime}, 3,3^{\prime}, 4,44^{\prime}, 5-h e p t a c h l o r o b i p h e n y l$

$2,2^{\prime}, 3,3^{\prime}, 4,4^{\prime}, 5$-heptachlorobipheny
$2,2^{\prime}, 3,4,4^{\prime}, 5,5^{\prime}$-heptachlorobiphenyl

$2,2^{\prime}, 3,4,4^{\prime}, 5,5^{\prime}$-heptachlorobipheny
$2,2^{\prime}, 3,4^{\prime}, 5,55^{\prime}, 6$-heptachlorobiphenyl

2,6-Dichorobiphenyl

3,5-Dichorobiphenyl

2,3,4-trichorobiphenyl

2,2',4,6-tetrachorobipheny

3,3',4,6-tetrachorobipheny

2,3,3',4-tetrachorobiphenyl

2,2', 4,6,6'-pentachorobiphenyl

2,2',3,4,6,6'-pentachorobiphenyl

$2,2^{\prime}, 3,4,4^{\prime}, 5,6,6^{\prime}$-octachlorobiphenyl

naphthalene

acenaphthene

acenaphthylene

fluorene

phenanthrene

anthracene

fluoranth

benzo[a]anthracen

chrysene

benzo[e]pyrene

benzo[a]pyrene

benzo[ghi]perylene

indeno[1,2,3-cd]pyrene

Naphtalene-D8

Fluorene-D10

Phenanthrene D10

Fluoranthene-D10

Chrysene-D10

Benz(e)pyrene-D12

Perylene-D12

Perylene-D12

Type ICES code in righthand cell

Type ICES code in righthand cel

Type ICES code in righthand cel

Type ICES code in righthand cell

Type ICES code in righthand cell

Type ICES code in righthand cell

Type ICES code in righthand cell

Type ICES code in righthand

Type ICES code in righthand cell

Type ICES code in righthand cell

Type ICES code in righthand cel

Type ICES code in righthand ce

Type ICES code in righthand cell

Type ICES code in righthand cell

Type ICES code in righthand cell

Type ICES code in righthand cell

Type ICES code in righthand cell

Type ICES code in righthand cell

Type ICES code in righthand cell

Type ICES code in righthand cell

Type ICES code in righthand cell

Type ICES code in righthand cell

Type ICES code in righthand cell

Type ICES code in righthand cell

Type ICES code in righthand cell

Type ICES code in righthand cell

Type ICES code in righthand cell

Type ICES code in righthand cell
Type ICES code in righthand cell
Name Martin M. Larsen

Email mml@dmu.dk

Tel $\quad \frac{1546301259}{4}$

Institute NERI, Denmark

$\begin{array}{ll}\text { StatC } & \text { NERI, Denmark } \\ \text { NERO4 }\end{array}$

Empty06

Empty06

DDXAr

XCrd

WTRxDepth

STRXDepth

SedxDes

SedxDes

SedxCon
$\mathrm{SCXNr}$

MB

DDxStart

Msed

SlurryDW

TxExp

DDxEnd

Days

NER04

Sample
28-Sep-06

58.825

Procedural Sample for

ref lab

Total sediment Pore water

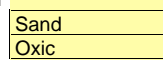

Q4

NO lab sample

4

Foppe?

724.122
49

20

Foppe?

\#VALUE

Com 1

Com1

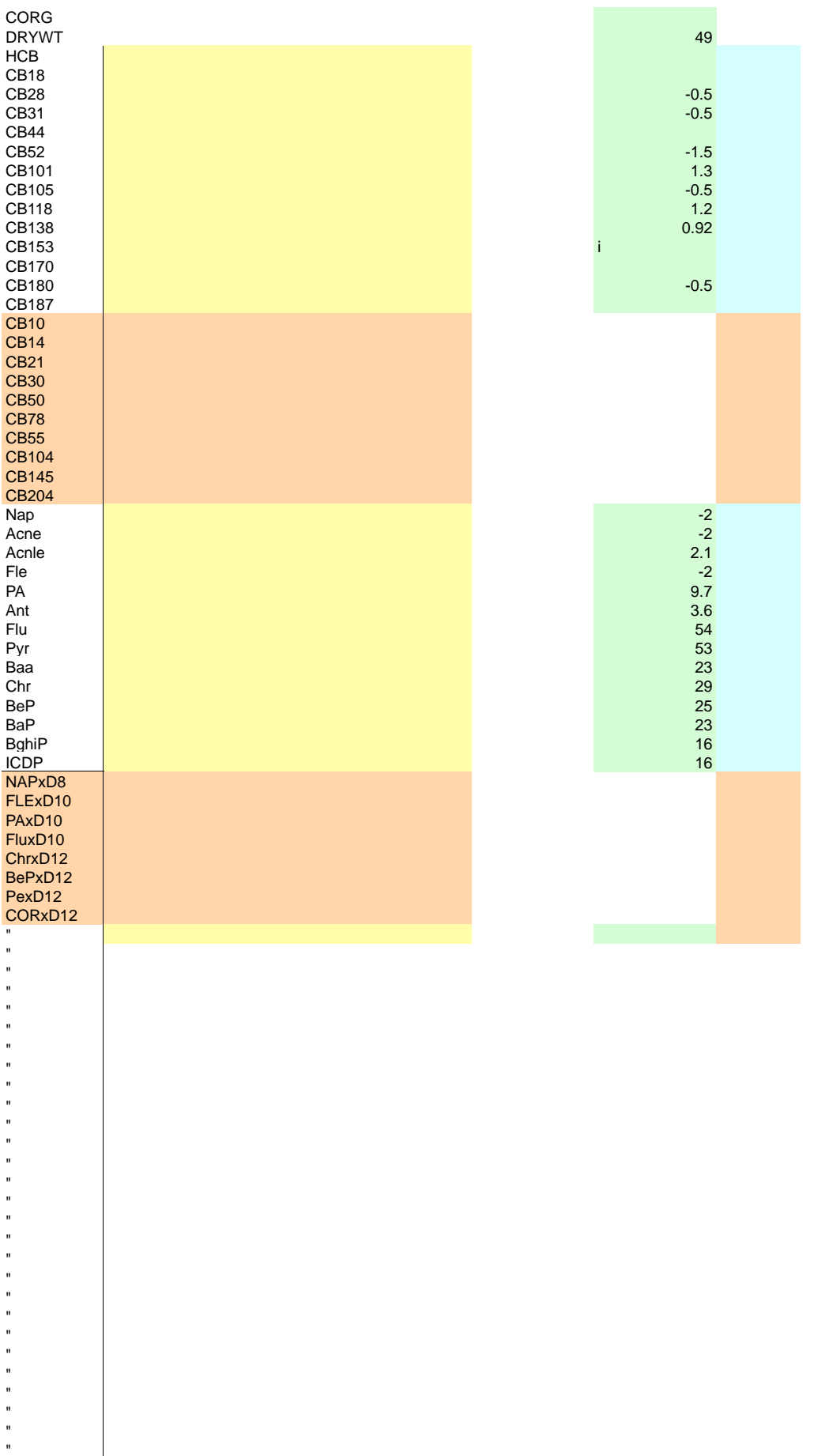


Who filled this form

email

Telephone (international)

Participant

Participant code \#

Station code \#

\section{Heading line}

Arrival date of PS material

Coordinate $x$ (decimal degrees) \#

Coordinate y (decimal degrees)\#

Water depth

Sampling depth

Decribe sediment

Condition of sediment

Bottle number \#

Bottle weight before extraction

Date of exposure to sediment \#

Dry weight of exposed sediment \#

Dry weight percentage in sediment

Approx Temperature of exposure $\left({ }^{\circ} \mathrm{C}\right)$

End date of exposure.\#

Exposed (d)

Bottle weight after extraction \#

Comment

Flim damaged? In \% surface \#

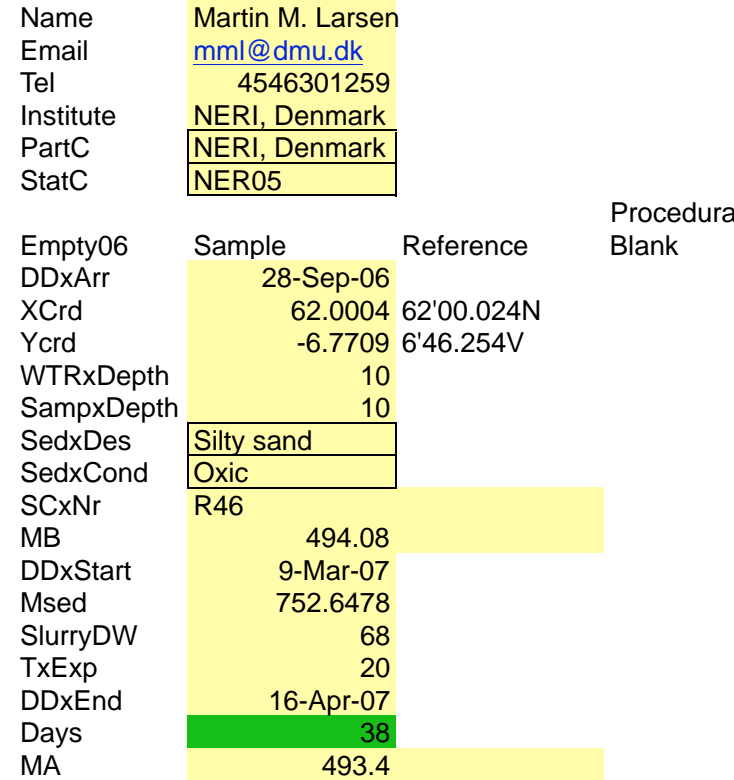

Sample for ref lab

Total sediment Pore water

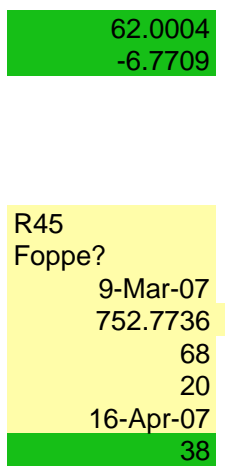

organic carbon

Dry weight \%

hexachlorobenzene

2,2',5-trichlorobiphenyl

2,4,4'-trichlorobiphenyl

2,4',5-trichlorobiphenyl

2,2',3,5'-tetrachlorobiphenyl

2,2',5,5'-tetrachlorobiphenyl

2,2',4,5,5'-pentachlorobiphenyl

2,3,3',4,4'-pentachlorobiphenyl

2,3',4,4',5-pentachlorobiphenyl

2,2',3,4,4',5'-hexachlorobiphenyl

2,2 ', 4,4',5,5'-hexachlorobiphenyl

2,2',3,3',4,4',5-heptachlorobiphenyl

2,2',3,4,4',5,5'-heptachlorobiphenyl

2,2',3,4',5,5',6-heptachlorobiphenyl

2,6-Dichorobiphenyl

3,5-Dichorobiphenyl

2,3,4-trichorobipheny

2,4,6-trichorobiphenyl

2,2',4,6-tetrachorobiphenyl

3,3',4,6-tetrachorobiphenyl

2,3,3',4-tetrachorobiphenyl

2,2', 4,6,6'-pentachorobiphenyl

2,2',3,4,6,6'-pentachorobiphenyl

2,2',3,4,4',5,6,6'-octachlorobiphenyl

naphthalene

acenaphthene

acenaphthylene

fluorene

phenanthrene

anthracene

fluoranthene

pyrene

benzo[a]anthracene

chrysene

benzo[e]pyrene

benzo[a]pyrene

benzo[ghi]perylene

indeno[1,2,3-cd]pyrene

Naphtalene-D8

Fluorene-D10

Phenanthrene D10

Fluoranthene-D10

Chrysene-D10

Benz(e)pyrene-D12

Perylene-D12

Coronene-D12
CORG

DRYWT

HCB

CB18

CB28

CB31

CB44

CB52

CB101

CB105

CB118

CB138

CB153

CB170

CB180

CB187

CB10

CB14

CB21

CB30

CB50

CB78

CB55

CB104

CB145

CB204

Nap

Acne

Acnle

Fle

PA

Ant

Flu

Pyr

Baa

Chr

$\mathrm{BeP}$

$\mathrm{BaP}$

BghiP

ICDP

PAHanalysis by NIVA - low PAH's in sediment evaporated during preconcentration $50 \%$

NAPXD8

FLExD10

PAxD10

FluxD10

ChrxD12

BePxD12

PexD12

Type ICES code in righthąifttGSH HD:User"s:mml:F-drev:grndstof:Tilbud:NMR_PassiveSamplers:final_submission:SEDxNER05.xIs 
Sediment results of Passi Field code

Who filled this form

email

Telephone (international)

Participant

Participant code \#

Station code \#

Heading line

Arrival date of PS material

Coordinate $x$ (decimal degrees) \#

Coordinate y (decimal degrees)\#

Water depth

Sampling depth

Decribe sediment

Condition of sediment

Bottle number \#

Bottle weight before extraction

Date of exposure to sediment \#

Dry weight of exposed sediment \#

Dry weight percentage in sediment

Approx Temperature of exposure $\left({ }^{\circ} \mathrm{C}\right)$

End date of exposure.\#

Exposed (d)

Bottle weight after extraction \#

Comment

Flim damaged? In \% surface \#

organic carbon

Dry weight $\%$

hexachlorobenzene

2,2',5-trichlorobiphenyl

2,4,4'-trichlorobiphenyl

2,4',5-trichlorobiphenyl

2,2',3,5'-tetrachlorobiphenyl

2,2',5,5'-tetrachlorobiphenyl

2,2',4,5,5'-pentachlorobiphenyl

2,3,3',4,4'-pentachlorobiphenyl

2,3',4,4',5-pentachlorobiphenyl

2,2',3,4,4',5'-hexachlorobiphenyl

$2,2^{\prime}, 4,4$ ', $5,5^{\prime}$-hexachlorobiphenyl

2,2',3,3',4,4',5-heptachlorobiphenyl

$2,2^{\prime}, 3,4,4^{\prime}, 5,5^{\prime}$-heptachlorobiphenyl

$2,2^{\prime}, 3,4^{\prime}, 5,5^{\prime}, 6$-heptachlorobiphenyl

2,6-Dichorobiphenyl

3,5-Dichorobiphenyl

2,3,4-trichorobiphenyl

2,4,6-trichorobiphenyl

2,2',4,6-tetrachorobiphenyl

3,3',4,6-tetrachorobiphenyl

2,3,3',4-tetrachorobiphenyl

2,2',4,6,6'-pentachorobiphenyl

2,2',3,4,6,6'-pentachorobiphenyl

$2,2^{\prime}, 3,4,4$ ', $5,6,6$ '-octachlorobiphenyl

naphthalene

acenaphthene

acenaphthylene

fluorene

phenanthrene

anthracene

fluoranthene

pyrene

benzo[a]anthracene

chrysene

benzo[e]pyrene

benzo[a]pyrene

benzo[ghi]perylene

indeno[1,2,3-cd]pyrene

Naphtalene-D8

Fluorene-D10

Phenanthrene D10

Fluoranthene-D10

Chrysene-D10

Benz(e)pyrene-D12

Perylene-D12

Coronene-D12

Type ICES code in righthand cell

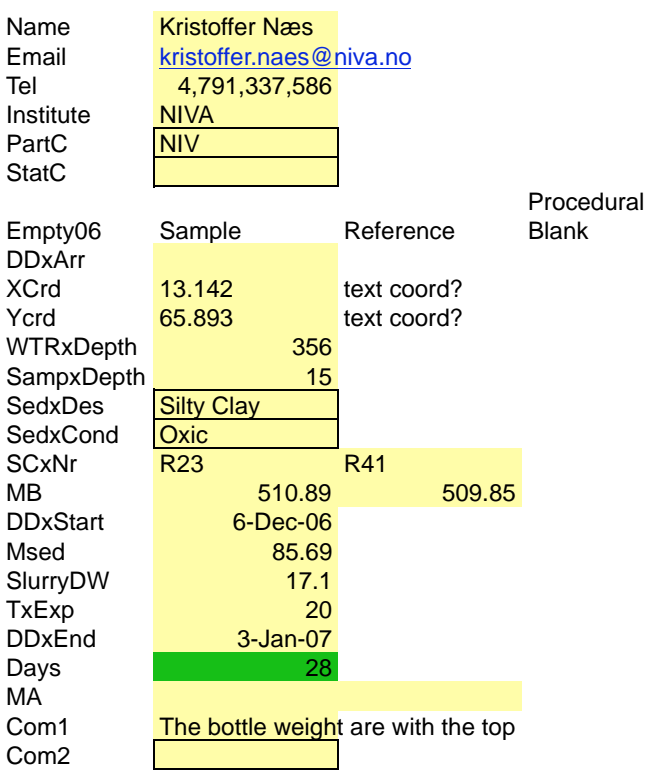

Sample for

ref lab

Total sediment Pore water

13.142

65.893

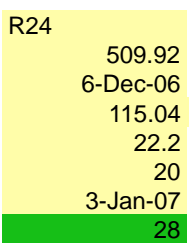

CORG

DRYWT

HCB

CB18

CB28

CB31

CB44

CB52

CB101

CB105

CB118

CB138

CB153

CB170

CB180

CB187

CB10

CB14

CB21

CB30

CB50

CB78

CB55

CB104

CB145

CB204

Nap

Acne

Acnle

$\mathrm{Fle}$

PA

Ant

Flu

Pyr

Baa

Chr

BeP

BaP

Bghip

NAPXD8

FLExD10

FLExD10

FluxD10

ChrxD12

BePxD12

PexD12

CORxD12
11.9

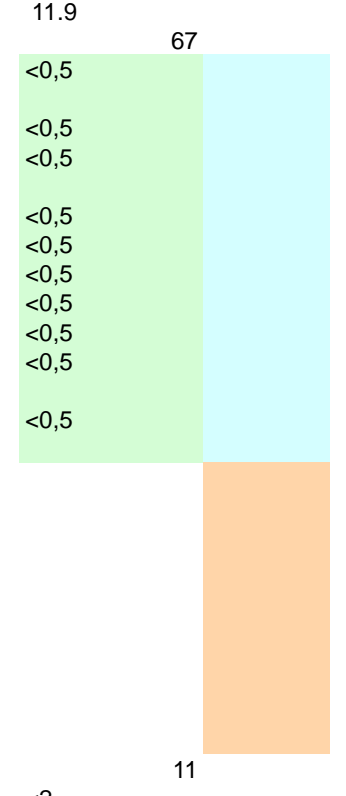

$<2$

$<10$

$<10$

610

470

510

1100

1200

570

840 
Sediment results of Pas Field code

\begin{tabular}{|c|c|c|c|c|c|c|c|}
\hline Who filled this form & Name & Kristoffer Næs & & \multirow[b]{7}{*}{$\begin{array}{l}\text { Procedural } \\
\text { Blank }\end{array}$} & \multirow[b]{7}{*}{$\begin{array}{l}\text { Sample for } \\
\text { ref lab }\end{array}$} & \multirow{8}{*}{ Total sediment } & \multirow[b]{7}{*}{ Pore water } \\
\hline email & Email & kristoffer.naes@n & \multirow[b]{6}{*}{ Reference } & & & & \\
\hline Telephone (international) & Tel & $4,791,337,586$ & & & & & \\
\hline Participant & Institute & NIVA & & & & & \\
\hline Participant code \# & PartC & NIV & & & & & \\
\hline Station code \# & StatC & & & & & & \\
\hline Heading line & Empty06 & Sample & & & & & \\
\hline Arrival date of PS material & DDxArr & & & & & & \\
\hline Coordinate $x$ (decimal degrees) \# & XCrd & 007.986533 & text coord? & & 007.986533 & & \\
\hline Coordinate y (decimal degrees)\# & Ycrd & 58.112000 & text coord? & & 58.112000 & & \\
\hline Water depth & WTRxDepth & 17 & & & & & \\
\hline Sampling depth & SampxDepth & 15 & & & & & \\
\hline Decribe sediment & SedxDes & Silty Clay & & & & & \\
\hline Condition of sediment & SedxCond & Oxic & & & & & \\
\hline Bottle number \# & $\mathrm{SCXNr}$ & R41 & & & R50 & & \\
\hline Bottle weight before extraction & MB & 509.33 & & & 508.98 & & \\
\hline Date of exposure to sediment \# & DDxStart & 26-Feb-07 & & & 26-Feb-07 & & \\
\hline Dry weight of exposed sediment \# & Msed & 43.57 & & & 44.07 & & \\
\hline Dry weight percentage in sediment & SlurryDW & 7.2 & & & 7.2 & & \\
\hline Approx Temperature of exposure $\left({ }^{\circ} \mathrm{C}\right)$ & TxExp & 20 & & & 20 & & \\
\hline End date of exposure.\# & DDxEnd & 26-Mar-07 & & & 26-Mar-07 & & \\
\hline Exposed (d) & Days & 28 & & & 28 & & \\
\hline Bottle weight after extraction \# & MA & & & & & & \\
\hline Comment & Com1 & The bottle weight & are with the top & & & & \\
\hline Flim damaged? In \% surface \# & Com2 & & & & & & \\
\hline
\end{tabular}

organic carbon

Dry weight \%

hexachlorobenzene

2,2',5-trichlorobiphenyl

2,4,4'-trichlorobiphenyl

2,4',5-trichlorobiphenyl

2,2',3,5'-tetrachlorobiphenyl

2,2',5,5'-tetrachlorobiphenyl

$2,2^{\prime}, 4,5,5^{\prime}$-pentachlorobiphenyl

2,3,3',4,4'-pentachlorobiphenyl

2,3',4,4',5-pentachlorobiphenyl

2,2',3,4,4',5'-hexachlorobiphenyl

2,2', 4, 4',5, ''-hexachlorobiphenyl

2,2',3,3',4,4',5-heptachlorobiphenyl

$2,2^{\prime}, 3,4,4$ ' $5,5^{\prime}$-heptachlorobiphenyl

2,2',3,4',5,5',6-heptachlorobiphenyl

2,6-Dichorobiphenyl

3,5-Dichorobiphenyl

2,3,4-trichorobiphenyl

2,4,6-trichorobiphenyl

2,2',4,6-tetrachorobiphenyl

3,3', 4,6-tetrachorobiphenyl

2,3,3',4-tetrachorobiphenyl

2,2',4,6,6'-pentachorobiphenyl

2,2',3,4,6,6'-pentachorobiphenyl

2,2 ',3,4,4',5,6,6'-octachlorobiphenyl

naphthalene

acenaphthene

acenaphthylene

fluorene

phenanthrene

anthracene

fluoranthene

pyrene

benzo[a]anthracene

chrysene

benzo[e]pyrene

benzo[a]pyrene

benzo[ghi]perylene

indeno[1,2,3-cd]pyrene

Naphtalene-D8

Fluorene-D10

Phenanthrene D10

Fluoranthene-D10

Chrysene-D10

Benz(e)pyrene-D12

Perylene-D12

Coronene-D12

Type ICES code in righthand cell

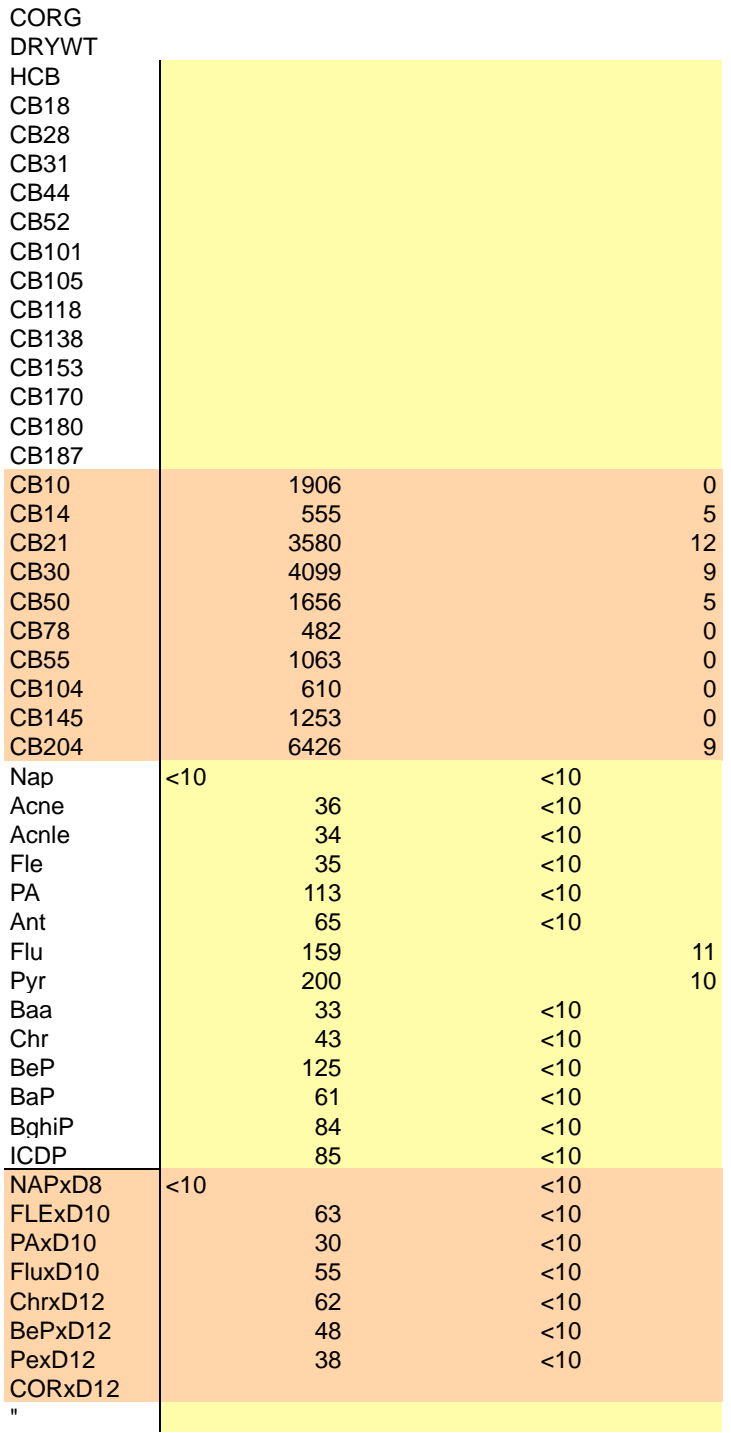

36 
Sediment results of Pas Field code

\begin{tabular}{|c|c|c|c|c|c|c|c|}
\hline $\begin{array}{l}\text { Who filled this form } \\
\text { email }\end{array}$ & $\begin{array}{l}\text { Name } \\
\text { Email }\end{array}$ & $\begin{array}{l}\text { Kristoffer Næs } \\
\text { kristoffer.naes@n }\end{array}$ & hiva.no & & & & \\
\hline Telephone (international) & Tel & & & & & & \\
\hline Participant & Institute & NIVA & & & & & \\
\hline Participant code \# & PartC & \begin{tabular}{|l|} 
NIV \\
\end{tabular} & & & & & \\
\hline Station code \# & StatC & & & & & & \\
\hline Heading line & Empty06 & Sample & Reference & $\begin{array}{l}\text { Procedural } \\
\text { Blank }\end{array}$ & $\begin{array}{l}\text { Sample for } \\
\text { ref lab }\end{array}$ & Total sediment & Pore water \\
\hline Arrival date of PS material & DDxArr & & & & & & \\
\hline Coordinate $\times$ (decimal degrees) \# & XCrd & 005.031 & text coord? & & 005.031 & & \\
\hline Coordinate y (decimal degrees)\# & Ycrd & 59.324 & text coord? & & 59.324 & & \\
\hline Water depth & WTRxDepth & 11 & & & & & \\
\hline Sampling depth & SampxDepth & 15 & & & & & \\
\hline Decribe sediment & SedxDes & Silty Clay & & & & & \\
\hline Condition of sediment & SedxCond & Oxic & & & & & \\
\hline Bottle number \# & $\mathrm{SCxNr}$ & R43 & R50 & & R49 & & \\
\hline Bottle weight before extraction & $\mathrm{MB}$ & 510.12 & 509.46 & & 509.75 & & \\
\hline Date of exposure to sediment \# & DDxStart & 6-Dec-06 & & & 6-Dec-06 & & \\
\hline Dry weight of exposed sediment \# & Msed & 104.81 & & & 94.24 & & \\
\hline Dry weight percentage in sediment & SlurryDW & 20.4 & & & 18.7 & & \\
\hline Approx Temperature of exposure $\left({ }^{\circ} \mathrm{C}\right)$ & TxExp & 20 & & & 20 & & \\
\hline End date of exposure.\# & DDxEnd & 3-Jan-07 & & & 3-Jan-07 & & \\
\hline Exposed (d) & Days & 28 & & & 28 & & \\
\hline Bottle weight after extraction \# & MA & & & & & & \\
\hline Comment & Com1 & & & & & & \\
\hline Flim damaged? In \% surface \# & Com2 & & & & & & \\
\hline
\end{tabular}

organic carbon

Dry weight \%

hexachlorobenzene

2,2',5-trichlorobiphenyl

2,4,4'-trichlorobipheny

2,4',5-trichlorobiphenyl

2,2',3,5'-tetrachlorobiphenyl

$2,2^{\prime}, 5,5^{\prime}$-tetrachlorobiphenyl

2,2',4,5,5'-pentachlorobiphenyl

2,3,3',4,4'-pentachlorobiphenyl

2,3',4,4',5-pentachlorobiphenyl

2,2',3,4,4',5'-hexachlorobiphenyl

$2,2^{\prime}, 4,4$ ',5, '-hexachlorobiphenyl

2,2',3,3',4,4',5-heptachlorobiphenyl

$2,2^{\prime}, 3,4,4^{\prime}, 5,5^{\prime}$-heptachlorobiphenyl

$2,2^{\prime}, 3,4^{\prime}, 5,5^{\prime}, 6$-heptachlorobiphenyl

2,6-Dichorobiphenyl

3,5-Dichorobiphenyl

2,3,4-trichorobiphenyl

2,4,6-trichorobiphenyl

2,2',4,6-tetrachorobiphenyl

3,3',4,6-tetrachorobiphenyl

2,3,3',4-tetrachorobiphenyl

2,2',4,6,6'-pentachorobiphenyl

2,2',3,4,6,6'-pentachorobiphenyl

2,2 ', $3,4,4$ ', $5,6,6$ '-octachlorobiphenyl

naphthalene

acenaphthene

acenaphthylene

fluorene

phenanthrene

anthracene

fluoranthene

pyrene

benzo[a]anthracene

chrysene

benzo[e]pyrene

benzo[a]pyrene

benzo[ghi]perylene

indeno[1,2,3-cd]pyrene

Naphtalene-D8

Fluorene-D10

Phenanthrene D10

Fluoranthene-D10

Chrysene-D10

Benz(e)pyrene-D12

Perylene-D12

Coronene-D12

Type ICES code in righthand cell

CORG

DRYWT

HCB

CB18

CB28

CB31

CB44

CB52

CB101

CB105

CB118

CB138

CB153

CB180

CB187

CB10

CB14

CB21

CB30

CB50

CB78

CB55

CB104

CB145

CB204

Nap

Acne

Acnle

Fle

PA

Ant

Flu

Pyr

Baa

Chr

BeP

BaP

Bghip

ICDP

NAPxD8

FLExD10

PAXD10

FluxD10

ChrxD12

BePxD12

PexD12

CORXD12
13.2

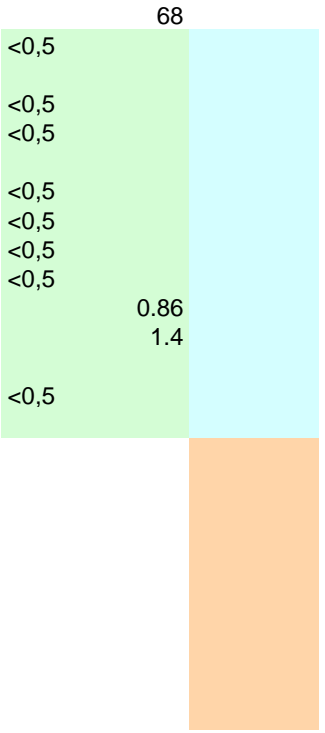

2.2

53

520

1300

1200

950

1400

2400

2200

2200

1900 